\title{
A PRODUÇÃO DAS CIÊNCIAS HUMANAS SOBRE FUTEBOL NO BRASIL: UM PANORAMA (1990-2009)*
}

\author{
Sérgio Settani Giglio \\ Doutorando em Educação Física pela Universidade de São Paulo e \\ professor da Universidade Nove de Julho/SP
}

Enrico Spaggiari

Doutorando em Antropologia Social pela Faculdade de Filosofia, Letras e Ciências Humanas da Universidade de São Paulo e bolsista da Fundação de Amparo à Pesquisa do Estado de São Paulo

\section{Resumo}

Este artigo apresenta um mapeamento da produção brasileira sobre futebol nos últimos vinte anos, com base em dissertações e teses, bem como trabalhos em revistas acadêmicas que publicaram dossiês sobre futebol e/ou esporte. Este levantamento permite inferir que, embora a produção acadêmica sobre o tema já seja significativa, falta ainda um maior intercâmbio de informações entre os pesquisadores e universidades para a consolidação deste tema de estudos no Brasil.

\section{Palavras-chave}

mapeamento $\bullet$ futebol $\bullet$ ciências humanas.

\section{Correspondência}

Universidade de São Paulo

Escola de Educação Física e Esporte

Departamento de Pedagogia do Movimento do Corpo Humano

Av. Prof. Melo de Morais, 65

05508-030 - Cidade Universitária - São Paulo - SP

E-mails: ssgiglio@gmail.com; enricospaggiari@yahoo.com.br

Agradecemos a leitura atenta de Fernando de Luiz Brito Vianna. 


\title{
THE HUMANITIES PRODUCTION ABOUT FOOTBALL IN BRAZIL: AN OVERVIEW \\ $(1990-2009)^{*}$
}

\author{
Sérgio Settani Giglio \\ Doctorate Student in Physical Education, Universidade de \\ São Paulo, and Professor at Universidade Nove de Julho/SP \\ Enrico Spaggiari \\ Doctorate Student in Social Anthropology at Faculdade de Filosofia, \\ Letras e Ciências Humanas of the Universidade de São Paulo and Fundação de \\ Amparo à Pesquisa do Estado de São Paulo's scholar
}

\begin{abstract}
This article presents a map of the brazilian production about football over the last twenty years, based on theses and dissertations, and papers in academic journals that have published dossiers about football and/or sport. This survey allows us to infer that while the academic research of the issue has to be meaningful, there is still a greater exchange of information among researchers and universities to further strengthen this subject of study in Brazil.
\end{abstract}

\section{Keywords}

map $\bullet$ football $\bullet$ humanities.

\section{Contact}

Universidade de São Paulo

Escola de Educação Física e Esporte

Departamento de Pedagogia do Movimento do Corpo Humano

Av. Prof. Melo de Morais, 65

05508-030 - Cidade Universitária - São Paulo - SP

E-mails: ssgiglio@gmail.com; enricospaggiari@yahoo.com.br

* We appreciate the careful reading of Fernando de Luiz Brito Vianna. 


\section{Introdução}

Mapear algo nunca é uma tarefa simples. Definir critérios significa estabelecer fronteiras e se mudamos os critérios teremos uma nova fronteira construída. Ao realizarmos o mapeamento da produção bibliográfica brasileira sobre futebol nos últimos vinte anos tivemos que estabelecer critérios para começar a busca pelas informações. Dessa forma, começamos a montar as nossas fronteiras que foram estabelecidas a partir de dois tipos de materiais: o que foi produzido nos mestrados e nos doutorados das universidades; e a publicação dos artigos acadêmicos sobre o tema. Contudo, o recorte não foi definido somente pelo período selecionado, mas também pela importância dos artigos produzidos a partir de dossiês sobre a temática futebolística. Tal recorte foi necessário devido ao espaço disponível para a análise e a quantidade considerável de artigos sobre futebol nas mais diversas revistas acadêmicas brasileiras ligadas às ciências humanas. ${ }^{1}$

A apresentação dos dados é seguida de um pequeno conjunto de informações disponíveis, com o objetivo de mostrar um panorama do que foi produzido nos últimos vinte anos sobre futebol, período que conta com o maior conjunto de trabalhos. Não temos como objetivo realizar uma análise das obras indicadas, mas, sim, apresentar as principais fontes para futuras pesquisas.

Entre os trabalhos que serviram como base para o mapeamento das referências, destacamos os dados levantados pelo Grupo de Estudos sobre Torcidas (Gefut), de Minas Gerais, que produziu um CD com as informações coletadas; e os dois artigos publicados na BIB - Revista Brasileira de Informação Bibliográfica em Ciências Sociais, por Luiz Henrique de Toledo (2001) e Pablo Alabarces (2004). ${ }^{2}$

Vale salientar, porém, que embora grande parte da produção brasileira tenha se concentrado no período entre 1990 e 2009, as primeiras contribuições dentro das ciências humanas para o estudo do futebol datam da década de 1940: o ensaio "O papel da magia no futebol", de Mário Miranda Rosa (1944), e a resenha do sociólogo Luiz Aguiar Costa Pinto (1947) do livro de Mário Filho, O negro no futebol brasileiro, então recém-lançado. Ambos foram publicados na revista Sociologia, primeiro periódico científico de ciências sociais no Brasil, editado pela então Escola Livre de Sociologia e Política e São Paulo (atual FESPSP). ${ }^{3}$ Contudo, a presença do tema em periódicos foi esporádica até o final da década

\footnotetext{
Embora a produção de livros também tenha crescido nos últimos anos, optamos, pelos motivos explicitados, por não incluir esse material.

2 Artigo que foi atualizado como capítulo do livro organizado por Luiz Carlos Ribeiro. Ver Alabarces (2007).

3 Sobre a importância da revista nas ciências sociais, ver Limongi (1987).
} 
de $1970 .{ }^{4}$ A produção passa também pelas dissertações e teses defendidas ${ }^{5}$ neste período, assim como pela publicação de dois livros fundamentais: Universo do futebol: esporte e sociedade brasileira, organizado pelo antropólogo Roberto DaMatta (1982a), e Futebol e cultura: coletânea de estudos, organizado por José Carlos Sebe Meihy e José Sebastião Witter (1982).

Diversos temas foram pesquisados ao longo dessas duas décadas: a inserção e a participação dos negros no futebol; as relações entre futebol e identidade nacional; discussões sobre estilos e escolas de futebol, principalmente de um "jogar à brasileira", mais conhecido como "futebol-arte"; a circulação de jogadores brasileiros no futebol internacional; a formação de jovens jogadores em escolinhas de futebol e categorias de base; etc. Dentre os principais temas, as pesquisas sobre torcidas organizadas, muito influenciadas pela proliferação de conflitos e casos de violência nos estádios no começo da década de 1990, tiveram um impacto decisivo dentro do processo de ampliação do cenário de estudos sobre esportes no Brasil.

Muitos desses temas foram germinados nestas em outras formas coletivas de debate e pesquisa. Além dos congressos, vale lembrar ainda que parte considerável desses trabalhos foi desenvolvida por pesquisadores vinculados a grupos de pesquisa, formados em sua maioria a partir do ano 2000, que têm no esporte seu principal tema de investigação. Dentre os grupos, podemos destacar: Núcleo de Sociologia do Futebol, criado em 1990 na Uerj e coordenado por Maurício Murad ${ }^{6}$ Núcleo de Estudos e Pesquisas sobre Esporte e Sociedade - Nepess, fundado em 2005 e coordenado por Marcos Alvito Pereira de Souza; Anima: Lazer, Animação Cultural e Estudos Culturais, criado em 1999 na UFRJ e coordenado por Victor Andrade de Melo e Fabio de Faria Peres; Sport: Laboratório de História do Esporte e do Lazer, formado em 2006 e também coordenado por Victor Andrade de Melo; Esporte e Cultura, criado em 1997 por Ronaldo Helal e Hugo Lovisolo; Núcleo de Estudos e Pesquisas em Sociologia do Futebol,

4 Algumas destas produções: o ensaio "O futebol no Brasil" de Anatol Rosenfeld, publicado em 1974 na revista Argumento no 2; o artigo "Futebol: ópio do povo ou drama de justiça social?" do antropólogo Roberto DaMatta, publicado na revista Novos Estudos n 4 de 1982b; o texto "O futebol no país do futebol" de Waldenyr Caldas, e a entrevista "Os cartolas são inevitáveis? Entrevista de Walter Casagrande a Waldenyr Caldas", ambos publicados em 1986 pela revista Lua Nova: Revista de Cultura e Política ${ }^{\circ} 10$.

5 Com destaque para as elaboradas no Programa de Pós-Graduação em Antropologia do Museu Nacional-UFRJ: O futebol brasileiro: instituição zero. Dissertação de Mestrado que Simoni Guedes defendeu em 1977, e Os gênios da pelota: um estudo do futebol como profissão. Dissertação defendida por Ricardo Augusto Benzaquen de Araujo em 1980.

6 O Núcleo de Sociologia do Futebol não existe mais. 
formado em 2006, vinculado à UFPE e coordenado por Josimar Jorge Ventura de Morais e Túlio Velho Barreto ${ }^{7}$ Associación Latinoamericana de Estudios Socioculturales del Deporte - Alesde, criada em 2008, conta com Wanderley Marchi Júnior com vice-presidente.

Portanto, a partir da década de 1990, as pesquisas, outrora contingentes, tornaram-se mais sistemáticas. Outros espaços decisivos para a consolidação dessa produção são os grupos de trabalho de eventos acadêmicos nacionais e latinoamericanos, tais como a Associação Brasileira de Antropologia - ABA, Reunião de Antropologia do Mercosul - RAM, Associação Nacional de Pós-Graduação e Pesquisa em Ciências Sociais - Anpocs, Associação Nacional dos Professores Universitários de História - Anpuh, Sociedade Brasileira de Sociologia - SBS, Associação Latino-Americana de Sociologia-Alas e outros. Embora a quantidade e qualidade das pesquisas apresentadas nos fóruns possam variar, a permanência destes ao longo dessa última década evidencia a importância das investigações voltadas ao campo esportivo.

Assim, a afirmação de que a produção sobre futebol é escassa consolidou-se no discurso acadêmico como sendo algo inquestionável, constantemente repetida em diversos meios. $\mathrm{O}$ nosso objetivo, ao mapear este quadro da produção sobre futebol nas ciências humanas, foi mostrar que a bibliografia não é tão insuficiente quanto se pensa. A produção existe. Porém, ainda precisa haver uma maior divulgação e intercâmbio das informações, dos trabalhos produzidos e dos grupos consolidados que se propõem a discutir e a pesquisar sobre o tema.

\section{Revistas e periódicos}

Embora este mapeamento abarque o período de 1990-2009, adotamos como ponto de partida o ano de 1994, uma data muito importante para o futebol brasileiro e também para a produção acadêmica brasileira dedicada ao tema futebolístico. Depois de 24 anos, o Brasil voltava a conquistar a Copa do Mundo de Futebol, disputada nos Estados Unidos. Logo após o término do principal evento futebolístico do planeta, era publicada uma edição da Revista USP, intitulada Dossiê Futebol, que atualmente se encontra esgotada. ${ }^{8}$ Estes aspectos foram destacados

Para um levantamento mais detido dos grupos de pesquisa voltados ao estudo do esporte, de forma geral, nas ciências humanas, conferir Ferreira (2007), que realizou um outro tipo de mapeamento sobre o que está sendo produzido na sociologia do esporte, um campo acadêmico em consolidação, e percebeu o maior espaço conferido à sociologia do esporte nas revistas de educação física do que nas revistas de sociologia.

${ }^{8}$ A versão em PDF da revista pode ser acessada no site: http://www.usp.br/revistausp/22/SUMA- 
pelo sociólogo José Carlos Bruni, professor do Departamento de Sociologia da FFLCH-USP e autor do texto de apresentação do dossiê, para justificar a publicação de um especial sobre a temática:

Foi pensando na inegável importância do futebol dentro da sociedade brasileira (mas não só) que surgiu a ideia de um dossiê sobre esse tema. Contribuir para uma interpretação crítica do futebol, alicerçada no tipo de conhecimento cultivado no interior da universidade, foi o fio condutor dos textos aqui coligidos, aproveitando a oportunidade aberta com a Copa do Mundo, quando o fenômeno do futebol torna-se mais visível, empolgante e rico do que ordinariamente (1994, p. 7).

A produção de dissertações, artigos e, principalmente, livros aumentara a partir da década de 1980, como bem lembrou Bruni ao apontar que "(...) como prova o próprio dossiê, já possuímos ampla bibliografia a respeito” (1994, p. 7). Assim, pode-se afirmar que a publicação do dossiê na Revista USP em 1994 trouxe uma decisiva visibilidade à temática futebol dentro das ciências sociais. A maioria dos artigos procurou investigar os significados do futebol para a sociedade brasileira por meio de diferentes aspectos: o desenvolvimento histórico do futebol no Brasil, aspectos e leituras artísticas do jogo, torcidas e torcedores de futebol.

Alguns destes aspectos foram retomados por Roberto DaMatta (1994) em "Antropologia do óbvio", artigo que se tornou referência para todos os estudiosos do universo futebolístico dentro das ciências humanas e que deu continuidade a temas trabalhados em seus estudos anteriores. A contribuição antropológica também se faz presente no texto de José Sérgio Leite Lopes (1994), “A vitória do futebol que incorporou a pelada", constantemente citado pelas produções atuais ${ }^{9}$ e que problematiza aspectos ligados ao amadorismo das primeiras décadas do século XX, ao posterior profissionalismo e ao jornalismo esportivo a partir da obra de Mário Rodrigues Filho.

Tais temas ressurgem em outros ensaios voltados à dimensão histórica da prática futebolística, como no texto "Futebol, metrópoles e desatinos" do historiador Nicolau Sevcenko (1994); "Aspectos sociopolíticos do futebol brasileiro" do sociólogo Waldenyr Caldas (1994); e "A bola na ponta da caneta" do jornalista Francisco Costa (1994). O diálogo entre futebol e outros planos estéticos, como literatura e artes plásticas, foi explorado no espaço reservado a textos do

RIO-22.htm. Acesso em: 21/11/2009.

9 Outro artigo de Leite Lopes que se tornou referência foi "Esporte, emoção e conflito social", publicado em 1995 na revista Mana, editada pelo Programa de Pós-Graduação em Antropologia Social do Museu Nacional da Universidade Federal do Rio de Janeiro. 
escritor Decio de Almeida Prado (1994); poemas de Antonio Medina Rodrigues, professor de Língua e Literatura Grega da FFLCH-USP; e ilustrações do artista plástico Antônio Lizárraga (1994), alternados com poemas de Júlio Plaza e Haroldo de Campos.

Dois artigos de jovens pesquisadores da USP encerravam o dossiê. Pautados por trabalhos recentes e até então inéditos, os textos "Transgressão e violência entre torcedores de futebol" do antropólogo Luiz Henrique de Toledo (1994) e "O futebol nas fábricas" da socióloga Fatima Martin Rodrigues Ferreira Antunes (1994) representaram um novo conjunto de pesquisas que começavam a ser desenvolvidas na década de 1990 e que paulatinamente ganhavam espaço nos periódicos das ciências sociais e veículos de mídia impressa. ${ }^{10}$ Nesse sentido, vale pontuar que a dissertação de mestrado de Luiz Henrique, Torcidas organizadas de futebol, foi premiada pela Anpocs, como a melhor dissertação de ciências sociais de 1994.

No mesmo ano de publicação da Revista USP - Dossiê Futebol, mais precisamente no segundo semestre de 1994, foi lançado o número zero da revista Pesquisa de Campo, editada pelo Núcleo de Sociologia do Futebol - vinculado ao Departamento de Ciências Sociais do Instituto de Filosofia e Ciências Humanas da Universidade do Estado do Rio de Janeiro - Uerj.

Fundado em maio de 1990, o Núcleo foi o primeiro centro de investigação latino-americano voltado à sociologia do futebol (Murad, 1999a). Idealizado e coordenado pelo sociólogo Mauricio Murad, o Núcleo de Sociologia do Futebol possui uma forte vocação transdisciplinar, marcado pelo diálogo entre as ciências sociais e outras áreas do conhecimento, como educação física e comunicação social, entre outras. Nesses vinte anos de existência, desenvolveu algumas linhas de pesquisa, bem como procurou organizar um importante acervo documental sobre a temática do futebol. Outra iniciativa do Núcleo foi a criação, em 1994, de uma disciplina eletiva denominada Sociologia do Futebol, a primeira de outras disciplinas que surgiriam nos anos seguintes em diferentes universidades brasileiras, ${ }^{11}$ cujo conteúdo programático, segundo Murad (1999a), dividia-se

${ }^{10}$ Cabe destacar os artigos: "Por que xingam os torcedores de futebol?" de Luiz Henrique de Toledo, publicado em 1993 na revista Cadernos de Campo nº 03, editada pelos alunos de pós-graduação em Antropologia Social da USP; e "Anarquistas e comunistas no futebol de São Paulo" de Fatima Ferreira Antunes, publicado em 1992 no jornal D. O. Leitura, suplemento cultural do Diário Oficial do Estado de São Paulo.

${ }^{11}$ No Departamento de História da USP, na pós-graduação, é oferecida a disciplina História Sociocultural do Futebol: impulso lúdico, composição e significações; na Faculdade de Educação Física da Unicamp, a disciplina Sociologia do Esporte; entre outras. 
em três unidades: a) o lugar teórico da sociologia do futebol; b) história social brasileira e mundial - do futebol ; c) futebol e cultura brasileira.

Portanto, embora a Revista USP tenha solidificado um espaço para o futebol no espaço acadêmico, é preciso destacar a experiência anterior e inovadora do Núcleo de Sociologia do Futebol. Concomitante à disciplina e às atividades de pesquisa, o núcleo editou cinco números da revista Pesquisa de Campo, que tinha como foco publicar artigos e outras produções sobre futebol. Como lembra Murad (1999a), ex-editor da revista, tratava-se de "um espaço de reunião e divulgação, exposição e discussão de ideias, trabalhos, propostas e pesquisas de estudiosos e ensaístas de formações diferenciadas". ${ }^{12}$ Pensado inicialmente para ter periodicidade semestral, o periódico parou de ser editado após seu quinto número por causa da falta de financiamento, mas seu pioneirismo é "um marco na história da implantação dos estudos do futebol nos cursos de Ciências Sociais no Brasil" (Murad, 2010). ${ }^{13}$

Dentre toda a produção publicada no periódico, destaca-se a mesa de debates "Homenagem ao João Saldanha", realizada em 21 de agosto de 1990, no mês seguinte à morte do cronista durante a Copa da Itália. Publicada no número zero da revista, contou com a participação do arquiteto Oscar Niemeyer, do jornalista e escritor Sergio Cabral, do ator Francisco Milani e do jornalista Alberto Léo (Murad, 1994). No número seguinte, o destaque foi a publicação de uma entrevista com o antropólogo Roberto DaMatta (1995).

Vale pontuar, ainda, que alguns temas tiveram destaque nas edições do periódico, principalmente artigos sobre as relações entre futebol e literatura por meio da obra de alguns escritores e cronistas, tanto os que jogavam contra a prática futebolística, entre eles Lima Barreto (Rodrigues Filho, 1995; Toledo, 1996) e Graciliano Ramos (Soares; Lovisolo, 1997), como aqueles que jogavam a favor, caso de José Lins do Rego (Coutinho, 1994). As relações de gênero também foram observadas, principalmente a partir do futebol feminino (Campos, 1994; Faria Jr., 1995; Pacheco; Cunha Jr., 1997), assim como a recente conquista da Copa do Mundo de 1994, evento transformado em objeto de pesquisa (Guedes, 1995; Rocha, 1995; 1996, Helal; Coelho, 1995). Outros temas que viriam a ser muito estudados nos anos posteriores, tal qual a questão da violência (Flores, 1995;

\footnotetext{
${ }^{12}$ Os números publicados tiveram as seguintes temáticas: número 0, junho de 1994 - Futebol: 100 anos de paixão brasileira; número 1, 1995 - Brasil: futebol tetracampeão do mundo; número 2, 1995 - Futebol e cultura brasileira; número 3/4, 1996 - Futebol: síntese da vida brasileira; número 5, 1997 - Futebol e cidadania.

${ }^{13}$ Conferir entrevista de Mauricio Murad no site www.ludopedio.com.br.
} 
Murad, 1996) e da participação dos negros no futebol brasileiro (Gordon Jr., 1995; 1996), dividiam espaço com pesquisas de objetos ainda hoje pouco investigados, como a linguagem futebolística (Feijó, 1995; 1997) e os "jogos de bola" de diferentes civilizações e outros períodos históricos (Lemos, 1995; Tonelli, 1997).

Portanto, não há dúvidas de que existe uma produção anterior à publicação do Dossiê Futebol, mas ela é incipiente e isolada. ${ }^{14}$ Sobre o isolamento das informações, bastante tempo depois, Pablo Alabarces reforça que "[...] la escasez de presentaciones colectivas y continentales señala más las dificultades de la circulación de los saberes sobre el campo de estudios que su ausencia" (2007, p. 174-175).

Porém, indo na contramão do discurso solidificado na academia de que a produção é pequena, Toledo (2001, p. 135) questionou, alguns anos depois, o frequente discurso de que seja difícil de encontrar material a respeito do futebol:

Já há algum tempo que as dissertações e as teses que tratam da dimensão esportiva não fazem mais a ressalva de que o assunto carece de bibliografia consistente. Esta ressalva, convertida muitas vezes em falta de cuidado ou despreparo na revisão bibliográfica, foi pega de surpresa na última década com o boom de trabalhos sobre os esportes no Brasil e a consolidação no meio acadêmico de áreas que deram um tratamento menos esporádico ao tema.

Em 1999, a revista Estudos Históricos n ${ }^{\circ} 23$ dedicou sua edição ao tema esporte e lazer, com contribuições de pesquisadores de diferentes áreas do conhecimento. Antropólogos, historiadores, geógrafos, sociólogos e educadores físicos produziram um conjunto de doze textos abordando o fenômeno esportivo, sendo oito especificamente sobre futebol, em sua maioria pautado por uma perspectiva histórica.

A seção Pontos de Vista trouxe dois ensaios: um mais teórico, "Considerações em torno das transformações do profissionalismo no futebol a partir da observação da Copa de 1998", do antropólogo José Sérgio Leite Lopes (1999); e o relato etnográfico de Eline Deccache Maia (1999), "Esporte e juventude no Borel", sobre as atividades de uma escolinha de futebol em uma favela na cidade do Rio de Janeiro.

A seção Artigos apresentava textos resultantes de duas pesquisas defendidas em 1998. Em "Ah! Eu sou gaúcho: o nacional e o regional no futebol brasileiro", Arlei Sander Damo (1999) discutia, a partir dos torcedores do clube Grêmio de Porto Alegre, algumas questões sobre pertencimento clubístico que investigara em

${ }^{14}$ Lembramos que a internet nos anos 1990 no Brasil era algo muito limitado. Hoje a internet possibilita a troca de informações de maneira muito mais rápida do que antigamente. 
sua dissertação de mestrado. ${ }^{15} \mathrm{O}$ segundo artigo, "História e a invenção das tradições no campo de futebol", de Antônio Jorge Soares (1999a), trazia alguns dos principais pontos sobre a temática racial que analisara em sua tese de doutorado. ${ }^{16}$

Além dos artigos e ensaios, a revista trazia um informe sobre o Núcleo de Sociologia do Futebol - UERJ, escrito por Maurício Murad (1999a), e a resenha "Futebol, sonho e decepção...", elaborada por Manoel Luis Lima Salgado Guimarães (1999), tecia comentários sobre o livro O Rio corre para o Maracanã.

Contudo, a seção Debates publicada pela revista Estudos Históricos merece destaque dentre as demais seções, pois trouxe uma polêmica e acalorada discussão envolvendo alguns dos principais pesquisadores brasileiros que investigam o universo futebolístico. Em "Sociologia, história e romance na construção da identidade nacional através do futebol”, Ronaldo Helal e Cesar Gordon Jr. (1999) teceram comentários e críticas à tese de doutorado de Antônio Jorge Soares, pesquisa que problematiza a história das relações raciais no universo futebolístico, principalmente a partir das leituras de alguns pesquisadores da clássica obra $O$ negro no futebol brasileiro, de Mário Filho, considerada por Soares um romance que, ao misturar ficção e realidade, produz uma "tradição inventada", ou seja, um discurso sobre o futebol brasileiro centrado na questão racial. A crítica de Helal e Gordon Jr. à busca do autor em desconstruir os alicerces teórico-metodológicos sobre o racismo no futebol encontrados em trabalhos recentes que utilizaram o livro de Mário Filho como base de dados levou à publicação, ainda na mesma edição, do texto "A modo de resposta" de Antonio Jorge Soares (1999b). Neste texto, Soares reforça a defesa de seus argumentos, embora reconheça a importância e qualidade da crítica elaborada por seus colegas pesquisadores.

Contudo, o debate iniciado pelo texto crítico realizado por Helal (1999) e Gordon Jr., e que colocava no centro da discussão a produção de pesquisadores vinculados ao Núcleo de Sociologia do Futebol, teve continuidade na edição $\mathrm{n}^{\circ}$ 24 da Estudos Históricos, lançada no mesmo ano. Em "Considerações possíveis de uma resposta necessária”, o sociólogo Maurício Murad (1999b), coordenador do Núcleo, retoma o estimulante debate acadêmico sobre a questão racial no futebol brasileiro e a formação de uma identidade nacional, abordando alguns aspectos assinalados por Antonio Jorge Soares (1999) no número anterior. De

\footnotetext{
${ }^{15}$ Para o que der e vier: o pertencimento clubístico no futebol brasileiro a partir do Grêmio Futebol Porto Alegrense e seus torcedores. Tese defendida no Programa de Antropologia Social da Universidade Federal do Rio Grande do Sul - UFRGS em 1998.

${ }^{16}$ Futebol, raça e nacionalidade no Brasil: releitura da história oficial. Tese defendida em 1998 na Universidade Gama Filho.
} 
modo mais incisivo, Murad critica os questionamentos epistemológicos, teóricos e metodológicos de Soares - sugerindo inclusive "um certo etnocentrismo acadêmico" -; ressalta a importância do livro de Mário Filho, para Murad (1999b), "um clássico no exato sentido do termo"; e defende a diversidade de fontes e a consistência das pesquisas sobre a temática do negro no futebol brasileiro, apontando a qualidade documental do acervo do Núcleo de Sociologia do Futebol.

Em 2003, dois periódicos publicaram importantes dossiês com o tema esporte. A revista Antropolítica n ${ }^{\circ} 14$, vinculada ao Programa de Pós-Graduação em Antropologia e Ciência Política da UFF, publicou o pequeno dossiê Esporte e Modernidade, porém muito valioso, como lembra Simoni Guedes em sua apresentação aos trabalhos:

Muitos antropólogos, nas duas últimas décadas, têm contribuído para a compreensão do lugar dos esportes na modernidade, revelando dimensões decisivas dos sistemas socioculturais atuais. Mas, sem qualquer sombra de dúvida, os três aqui reunidos neste primeiro dossiê da Antropolítica vêm contribuindo de modo particularmente relevante para o debate internacional sobre o tema (2003, p. 11).

O primeiro artigo, "Em torno da dialética entre igualdade e hierarquia: notas sobre as imagens e representações dos Jogos Olímpicos e do futebol no Brasil", traz uma reflexão comparativa de Roberto DaMatta (2003) sobre o espaço simbólico dos dois eventos na sociedade brasileira, sendo o primeiro menos valorizado no Brasil em comparação às Copas do Mundo de Futebol. No segundo texto, publicado em inglês, o antropólogo argentino Eduardo P. Archetti (falecido em 2005) percorre mais de meio século de história (do final do século XIX até a década de 1950) para analisar o futebol, bem como outros esportes na Argentina, como o polo, as corridas de carros e o boxe. Por fim, no terceiro e último texto, "Futebol e mídia: a retórica televisiva e suas implicações na identidade nacional, de gênero e religiosa”, a antropóloga Carmen Sílvia Moraes Rial (2003) investiga, tendo com base principalmente a Copa do Mundo de 1998, a construção do futebol enquanto um discurso social pela mídia televisiva.

No segundo semestre de 2003, a revista História: Questões \& Debates $\mathrm{n}^{\mathrm{o}}$ 39, editada pelo Programa de Pós-Graduação em História da UFPR, trouxe o dossiê Esporte e Sociedade com cinco artigos, sendo três internacionais, com destaque para os textos "Sobre problemas de identidade e emoções no esporte e no lazer: comentários críticos e contracríticos sobre as sociologias convencional e configuracional de esporte e lazer" do sociólogo Eric Dunning (2003) e "Globalização cultural nas fronteiras - o caso do futebol escocês" do sociólogo Richard Giulianotti (2003). Completavam o dossiê dois artigos sobre narrativas 
jornalísticas em contextos diferentes: no primeiro, a antropóloga Candice Vidal de Souza (2003) analisa a discussão sobre a "modernização" do futebol brasileiro por meio de matérias publicadas no jornal Folha de S.Paulo durante o ano de 1997; no segundo, com base no material de imprensa publicado em Buenos Aires no ano de 1925, Julio D. Frydenberg (2003) investiga questões de identidade e pertencimento nacional na Argentina, tendo como principal objeto o clube Boca Juniors. Para encerrar o dossiê, o artigo de Plínio José Labriola de Campos Negreiros (2003) procurava analisar as relações entre o futebol e a construção da identidade nacional no Brasil por meio de dois eventos especiais: Copa do Mundo de 1938 e a inauguração do Estádio do Pacaembu em 1940.

Neste novo século, foram criadas duas revistas específicas para as produções sobre a temática do esporte dentro das ciências sociais e humanas. Em 2005, surgiu a revista Esporte e Sociedade, criada por pesquisadores de diferentes áreas e universidades. Coordenada atualmente pelo historiador Bernardo Buarque de Hollanda, a revista trouxe em seu primeiro número uma edição quase toda dedicada à prática futebolística, espaço que, nos números seguintes, foi sendo compartilhado com pesquisas sobre outros esportes. Alguns dos artigos das primeiras edições, inclusive, tornaram-se referenciais importantes para trabalhos posteriores. Entre eles, "Senso de jogo" de Arlei Damo, publicado em 2005 no primeiro número da revista, que traz alguns dos resultados da tese de doutorado ${ }^{17}$ do autor, premiada pela Anpocs; e o texto "Futebol e sociabilidade: apontamentos sobre as relações jocosas futebolísticas" de Edison Gastaldo, ${ }^{18}$ publicado no terceiro número em 2006b. Nos demais números, outros artigos foram publicados, mas passaram a dividir espaços com trabalhos sobre diversas modalidades, já que a revista trata do esporte de forma geral.

Em 2008, foi criada a Record - Revista de História do Esporte, vinculada ao Programa de Pós-Graduação em História Comparada da UFRJ, ao grupo

${ }^{17}$ Do dom à profissão - Uma etnografia do futebol de espetáculo a partir da formação de jogadores no Brasil e na França. Tese defendida no Programa de Pós-Graduação em Antropologia Social da UFRGS em 2005. Atualmente, Arlei Damo vem focando a circulação de jogadores brasileiros de futebol profissional, "pés-de-obra" identificados tanto como pessoas e mercadorias às quais são atrelados valores e preços. Para conferir alguns pontos desta discussão, ainda que de forma inicial, conferir artigo de Damo (2008), "Dom, amor e dinheiro no futebol de espetáculo" na Revista Brasileira de Ciências Sociais.

${ }^{18}$ Autor que já se debruçou sobre diversos aspectos do universo do futebol e que atualmente investiga a sociabilidade masculina que está ligada aos contextos futebolísticos, principalmente cotidianos, e marcada por relações de jocosidade. Entre os vários artigos de Gastaldo, destacamse as análises das publicidades durante a Copa do Mundo (2001; 2002), do papel da mídia esportiva (2006a; 2009) e das performances de torcedores em bares durante as partidas (2005). 
Sport: Laboratório de História do Esporte e do Lazer e que tem Victor Andrade de Melo como editor-responsável. Voltada aos estudos de práticas corporais institucionalizadas, abarcando desde a dança até a educação física, a revista, ainda em seus primeiros números, indica que poderá contribuir para o quadro de produções sobre futebol.

Em 2008, foi lançada a Revista Brasileira de Futebol, fruto do curso de especialização em futebol da Universidade Federal de Viçosa (UFV). Esta revista é totalmente voltada ao futebol e possui artigos desde sobre treinamento esportivo até os que tratam o futebol como um fenômeno cultural.

Neste mesmo ano, a Horizontes Antropológicos, uma revista de grande visibilidade dentro do contexto antropológico, publicou, em seu trigésimo número, o dossiê Antropologia e Esporte, voltado quase integralmente ao universo futebolístico. De presente para seus leitores, trouxe uma seção Espaço Aberto internacional, composta por uma entrevista com Eric Dunning, "Esporte, violência e civilização: uma entrevista com Eric Dunning" conduzida por Édison Gastaldo (2008); um texto inédito em língua portuguesa, "As práticas e os espetáculos esportivos na perspectiva da etnologia" do antropólogo francês Christian Bromberger (2008), precedido por uma apresentação de Arlei Damo; e um texto-homenagem de Pablo Alabarces (2008) ao antropólogo argentino Eduardo Archetti, conhecido por seus trabalhos de cunho comparativo sobre o futebol e outros esportes na Argentina, seguido pela publicação de um artigo de Archetti, "El potrero y el pibe: territorio y pertenencia en el imaginario del fútbol argentino". ${ }^{19}$

Apesar do título do dossiê, todos os textos da seção Artigos discorrem sobre a temática futebolística, tendência que pode ser explicada pelo destaque desta modalidade - nos planos espetacularizado e cotidiano - quando comparada às demais práticas esportivas no Brasil. Predomínio que se reflete também na produção de pesquisas sobre os esportes brasileiros e suas relações com diversas questões sociais.

Marcado pelos resultados de investigações etnográficas sobre práticas e eventos esportivos, o especial da Horizontes Antropológicos abria e fechava sua seção de artigos com textos de dois dos mais importantes antropólogos voltados à temática esportiva, respectivamente, Carmen Rial (2008) e Luiz Henrique de Toledo (2008). Em "Rodar: a circulação dos jogadores de futebol brasileiros no exterior", Rial pesquisou a transferência de jogadores brasileiros por diversos países, principalmente os europeus. Toledo, por seu lado, em "Jogo livre: analo-

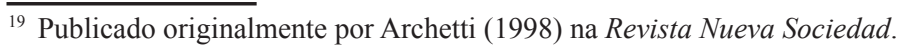


gias em torno das 17 regras do futebol", analisa as regras do futebol que possuem lógicas destoantes, com base em três abordagens antropológicas clássicas: o estruturalismo, o estrutural-funcionalismo e a configuracional.

Nos demais textos dessa seção, pesquisadores brasileiros compartilham páginas e temas com estudiosos argentinos em uma edição que trouxe, ainda, artigos transdisciplinares, exemplos da importância do diálogo de pesquisadores da educação física com os aportes teórico-metodológicos das ciências sociais, principalmente sobre a discussão e relação entre dom e futebol. Troca entre disciplinas que tem se mostrado muito produtiva para a consolidação dos estudos sobre futebol no Brasil.

Vale conferir, ainda, outros dossiês que foram publicados neste período, como o da Pensar a Prática (v. 10, n 1), de 2007, revista de educação física e ciências do esporte da Universidade Federal de Goiás; o dossiê História e Esporte da Revista do IHGB n ${ }^{\circ} 439$, publicado em 2008 pelo Instituto Histórico e Geográfico Brasileiro; e a revista Organizações e Sociedade no 48, de 2009, editada pela Escola de Administração da Universidade Federal da Bahia. Ainda em 2009, seria publicado o dossiê Antropologia do Esporte da revista Vibrant (Virtual Brazilian Anthropology), periódico online publicado pela Associação Brasileira de Antropologia - ABA.

Para além dos dossiês e artigos aqui mencionados, muitas outras revistas contribuíram para o debate sobre o fenômeno futebolístico nas ciências sociais e para a produção de novas pesquisas, colaborando assim para o fortalecimento da temática. Trata-se, contudo, de uma produção ainda distante da visibilidade merecida pela importância deste tema no Brasil. Como lembra Toledo (2001, p. 135), "em algumas revistas acadêmicas de reconhecida visibilidade no campo científico podemos observar um número irrisório de trabalhos que têm como tema os esportes. Isso, de certa forma, reflete um campo ainda em formação e afirmação institucional”.

Cenário a ser modificado pelos estudos mais recentes, muitos deles marcados pela interdisciplinaridade, que procuram teorizar o campo esportivo e investigar empiricamente as diferentes expressões e práticas futebolísticas.

\section{Teses e dissertações}

Para o levantamento de teses e dissertações, no primeiro momento, buscamos as informações nas páginas de todas as bibliotecas digitais das universidades federais e de algumas estaduais e particulares, especialmente as pontifícias universidades católicas, devido ao espaço que ocupam no cenário acadêmico brasileiro. 
Durante a busca, acessamos o banco de teses no portal da Coordenação de Aperfeiçoamento de Pessoal de Nível Superior - Capes..$^{20}$ Por ser um órgão de fomento à pesquisa, a base de dados da Capes foi um espaço de referência para atualizar o quadro de dados e explanar algumas dúvidas a respeito das informações coletadas. Porém, vale ressaltar que esse banco de teses e dissertações apresenta dados referentes à produção brasileira até 2008.

Além disso, em conjunto com esse levantamento, acessamos e conferimos uma série de informações coletadas pelo Grupo de Estudos sobre Futebol e Torcidas (Gefut), que realizou um rigoroso levantamento da produção acadêmica acerca do futebol nas ciências humanas e sociais, abarcando o período 1980 - 2007.

O critério definido para realizar a busca pelas teses e dissertações foi pela palavra futebol nos resumos dos trabalhos. Embora o nosso foco tenha sido a produção que esteja em diálogo com as ciências humanas e sociais, optamos por apresentar, como dados do levantamento, alguns trabalhos que foram produzidos em outras áreas do conhecimento como, por exemplo, trabalhos de engenharia ou arquitetura. Nestas áreas, especificamente, algumas temáticas estudadas - principalmente sobre a estrutura, edificação e usos dos estádios de futebol - permitem a construção de um importante diálogo com as ciências sociais.

Na tabela 1 podemos verificar a distribuição dos trabalhos de mestrado e doutorado pelas áreas do conhecimento. $\mathrm{O}$ item ciências sociais agrupa pesquisas provenientes da antropologia, sociologia e ciência política. Devido aos diferentes nomes que os programas de pós-graduação dão às áreas, optamos por reunir essa diversidade de pesquisas em um único item. Dessa forma, a história aparece sozinha enquanto categoria, pois havia uma uniformidade de informações quanto a essa área do conhecimento.

A educação física e as ciências sociais foram as áreas que mais alimentaram a produção acadêmica. A educação física, apenas aparentemente distante desse tipo de discussão, tornou-se referência em trabalhos amparados pelos referenciais das ciências humanas desde que inúmeros cursos de Educação Física incorporaram, em suas grades disciplinas para discutir os aspectos sociais de uma prática que durante muito tempo somente olhava para as questões biológicas.

${ }^{20}$ Conferir http://capesdw.capes.gov.br/capesdw/ 


\section{Gráfico 1 \\ Distribuição por áreas (número de trabalhos)}

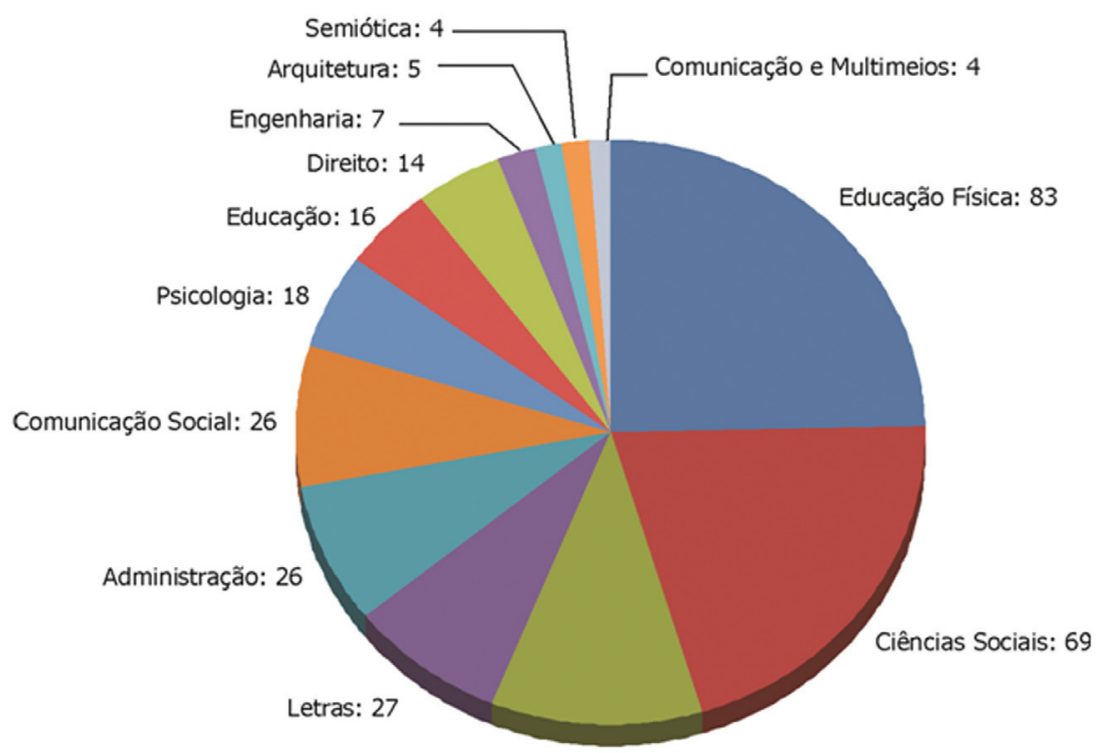

História: 36

Ao todo, no levantamento, foram catalogadas 27 áreas que promoveram estudos sobre o universo futebolístico. ${ }^{21}$ Abaixo, temos as áreas elencadas de acordo com o número total de produções:

${ }^{21}$ No gráfico 1 acima estão indicados os dados da coluna a esquerda, apresentados em destaque na tabela 1 abaixo. 
Tabela 1

Distribuição dos trabalhos de mestrado e doutorado sobre futebol por área - 1990-2009

\begin{tabular}{|l|c|c|}
\hline \multicolumn{1}{|c|}{ Áreas } & Total & \% \\
\hline Educação física & 83 & 23,31 \\
\hline Ciências sociais & 69 & 19,38 \\
\hline História & 36 & 10,11 \\
\hline Letras & 27 & 7,58 \\
\hline Administração & 26 & 7,30 \\
\hline Comunicação social & 26 & 7,30 \\
\hline Psicologia & 18 & 5,06 \\
\hline Educação & 16 & 4,49 \\
\hline Direito & 14 & 3,93 \\
\hline Engenharia & 7 & 1,97 \\
\hline Arquitetura & 5 & 1,40 \\
\hline Comunicação e semiótica & 4 & 1,12 \\
\hline Multimeios & 4 & 1,12 \\
\hline Geografia & 3 & 0,84 \\
\hline Religião & 3 & 0,84 \\
\hline Ciências contábeis & 3 & 0,84 \\
\hline Saúde coletiva & 2 & 0,56 \\
\hline Ciência da informação & 1 & 0,28 \\
\hline Design & 1 & 0,28 \\
\hline Economia & 1 & 0,28 \\
\hline Epidemiologia & 1 & 0,28 \\
\hline Hospitalidade & 1 & 0,28 \\
\hline Relações internacionais & 1 & 0,28 \\
\hline Turismo & 1 & 0,28 \\
\hline Integração da América & 1 & 0,28 \\
\hline Enfermagem & 1 & 0,28 \\
\hline Hebiatria & 1 & 0,28 \\
\hline
\end{tabular}

De acordo com os dados levantados, duas universidades fomentaram o maior número de pesquisas no período mapeado: a Universidade de São Paulo (USP) e a Pontifícia Universidade Católica de São Paulo (PUC-SP), ambas com 37 trabalhos. Vale destacar, porém, uma significativa dispersão da produção, visto que os trabalhos sobre futebol estão vinculados a 44 universidades diferentes.

As cinco primeiras universidades estão localizadas na região Sudeste. Vale realçar, ainda, que não aparece nenhuma universidade do Nordeste entre as 10 primeiras deste levantamento. Certamente, esse quadro irá se modificar nos próximos anos devido à atuação do Núcleo de Estudos e Pesquisas em Sociologia do Futebol, criado em Pernambuco. 
Tabela 2

Distribuição dos trabalhos de mestrado e doutorado sobre futebol por universidades - 1990-2009

\begin{tabular}{lll}
\hline & Total & \\
\hline USP & & \\
\hline PUC-SP & 37 & 10,39 \\
\hline Unicamp & 37 & 10,39 \\
\hline Universidade Gama Filho & 33 & 9,27 \\
\hline UFRJ & 26 & 7,30 \\
\hline UFRGS & 24 & 6,74 \\
\hline UFMG & 21 & 5,90 \\
\hline UNB & 18 & 5,06 \\
\hline UFSC & 16 & 4,49 \\
\hline UFPR & 16 & 4,49 \\
\hline Unesp & 13 & 3,65 \\
\hline UFBA & 10 & 2,81 \\
\hline Uerj & 8 & 2,25 \\
\hline UFPE & 8 & 2,25 \\
\hline PUC-RJ & 8 & 2,25 \\
\hline PUC-RS & 7 & 1,97 \\
\hline UFSM & 7 & 1,97 \\
\hline UFC & 6 & 1,69 \\
\hline UFF & 6 & 1,69 \\
\hline PUC-MG & 6 & 1,69 \\
\hline Universidade Metodista de São Paulo & 5 & 1,40 \\
\hline Ufscar & 5 & 1,40 \\
\hline Universidade Presbiteriana Mackenzie & 5 & 1,40 \\
\hline UEPG & 4 & 1,12 \\
\hline UFPA & 3 & 0,84 \\
\hline Puccamp & 3 & 0,84 \\
\hline Unisinos & 2 & 0,56 \\
\hline UFG & 2 & 0,56 \\
\hline UFPEL & 2 & 0,56 \\
\hline USP (Ribeirão Preto) & 2 & 0,56 \\
\hline Cásper Líbero & 2 & 0,56 \\
\hline Escola Superior de Teologia & 1 & 0,28 \\
\hline Faculdades Integradas Sant'Anna & 1 & 0,28 \\
\hline Ibmec São Paulo & 1 & 0,28 \\
\hline UEM & 1 & 0,28 \\
\hline Ufam & 1 & 0,28 \\
\hline Ufes & 1 & 0,28 \\
\hline UFMT & 1 & 0,28 \\
\hline UFRN & 1 & 0,28 \\
\hline & 1 & 0,28 \\
\hline
\end{tabular}




\begin{tabular}{lll}
\hline \multicolumn{1}{c}{ Instituição } & Total & $\mathbf{\%}$ \\
\hline Universidade Anhembi Morumbi & 1 & 0,28 \\
\hline Universidade Católica de Goiás & 1 & 0,28 \\
\hline Universidade Católica de Pernambuco & 1 & 0,28 \\
\hline Universidade de Pernambuco & 1 & 0,28 \\
\hline Universidade de Sorocaba & 1 & 0,28 \\
\hline
\end{tabular}

\section{Gráfico 2 \\ Produção brasileira sobre futebol por universidade (\%)}

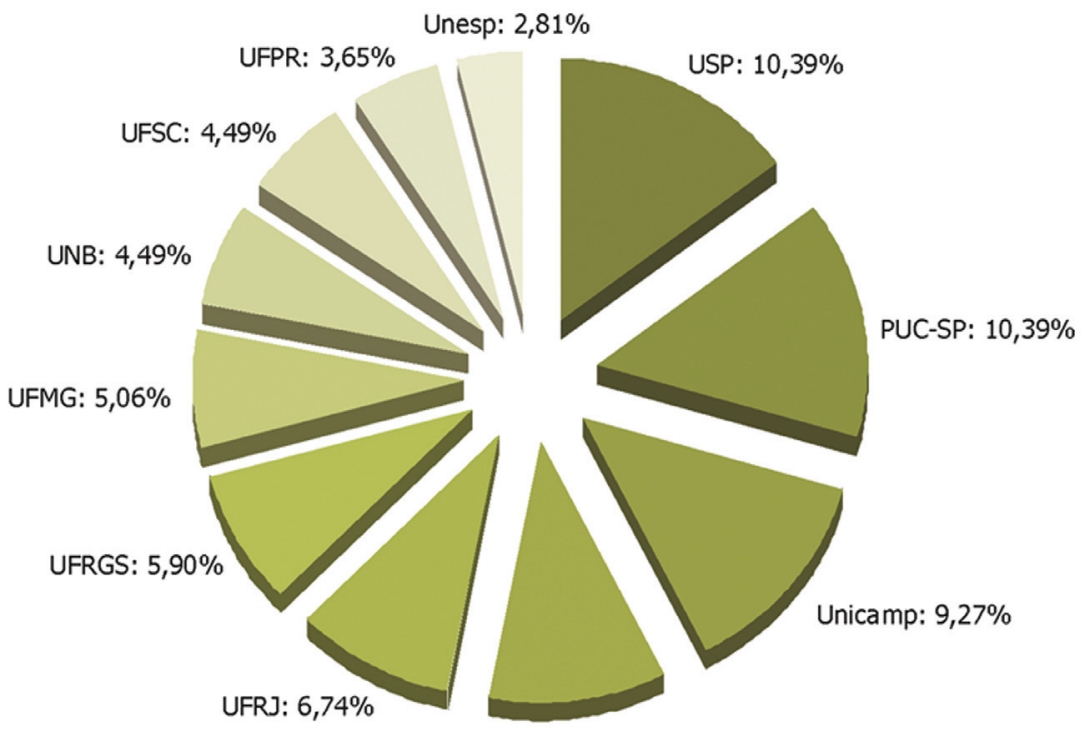

Universidade Gama Filho: 7,30\%

Para conferência, a lista completa (nome da pesquisa, autor, instituição, titulação, orientador e ano da defesa) das 356 pesquisas já concluídas ${ }^{22}$ e listadas acima pelas universidades encontra-se no Anexo 1 - Pesquisas concluídas, ao final desse artigo.

Entre os professores das universidades, Antonio Jorge Gonçalves Soares lidera a lista de orientações, com doze orientações na Universidade Gama Filho-RJ e uma na Universidade Federal do Espírito Santo, sendo dez orientações de mestrado e três de doutorado, o que representa $3,65 \%$ da produção nos últimos vinte anos.

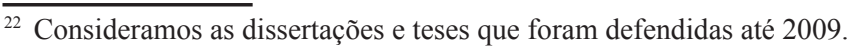


Logo em seguida, aparece Hugo Rodolfo Lovisolo, com cinco orientações pela Universidade Gama Filho-RJ e uma pela Universidade Estadual do Rio de Janeiro, sendo quatro orientações de mestrado e duas de doutorado. Com o mesmo número de orientações de Lovisolo, a antropóloga Márcia Regina da Costa, falecida em 2007, continua a ser uma referência para pesquisadores da temática futebolística. A professora da Pontifícia Universidade Católica de São Paulo (PUC-SP) orientou três trabalhos de mestrado e três de doutorado, todos vinculados ao Núcleo de Cultura Urbana da PUC, do qual era coordenadora. ${ }^{23}$

Esse levantamento permite inferir que, embora a USP possua o maior número de trabalhos produzidos, eles estão distribuídos por vários orientadores, já que nenhum professor da USP aparece entre os primeiros da lista. Segue o gráfico com a quantidade de orientações dos professores:

\section{Gráfico 3 \\ Orientadores dos trabalhos de mestrado e doutorado sobre futebol}

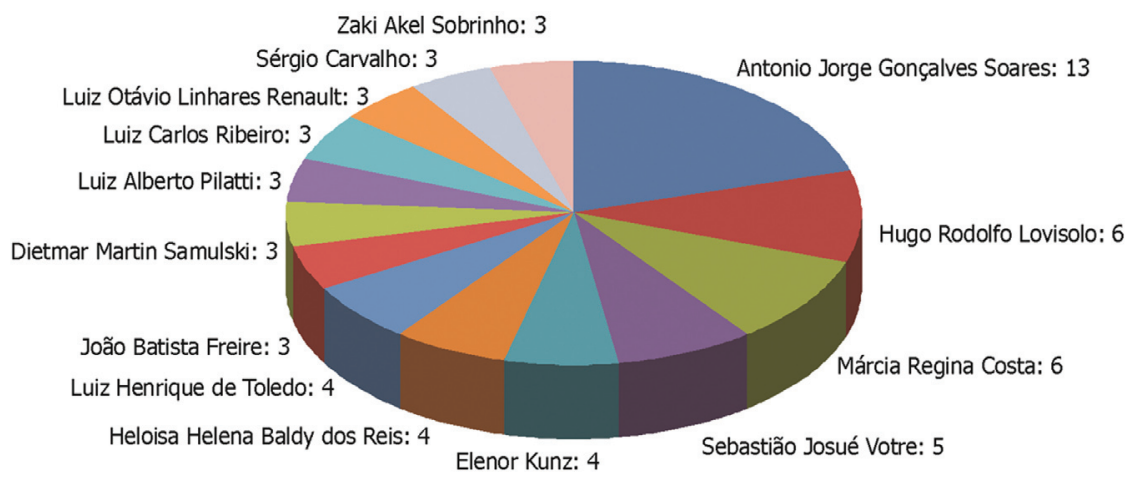

${ }^{23}$ Também pela Universidade Gama Filho, José Sebastião Votre orientou cinco trabalhos (três mestrados e dois doutorados), seguido por Elenor Kunz da Universidade Federal de Santa Catarina (quatro mestrados); Heloísa Helena Baldy dos Reis da Universidade Estadual de Campinas (quatro mestrados) e Luiz Henrique de Toledo da Universidade Federal de São Carlos (quatro mestrados); Dietmar Martin Samulski da Universidade Federal de Minas Gerais (três mestrados); João Batista Freire está atualmente na Universidade do Estado de Santa Catarina, porém realizou as orientações sobre futebol quando era professor da Universidade Estadual de Campinas (dois mestrados e um doutorado); Luiz Alberto Pilatti, sendo dois mestrados pela Universidade Estadual de Ponta Grossa e um mestrado pela Universidade Federal do Paraná; Luiz Carlos Ribeiro, com um mestrado e dois doutorados pela Universidade Federal do Paraná; Luiz Otávio Linhares Renault da Pontifícia Universidade Católica de Minas Gerais (três mestrados), Sérgio Carvalho da Universidade Federal de Santa Maria (três mestrados) e Zaki Akel Sobrinho da Universidade Federal do Paraná (dois mestrados e um doutorado). 
Conclui-se, também, que a produção concentra-se no mestrado, com 276 pesquisas ao todo. No doutorado, foram defendidas 78 teses. Conseguimos identificar dois trabalhos de livre docência sobre o fenômeno futebolístico. ${ }^{24}$ Ao compararmos os dados levantados com os obtidos pelo levantamento do Gefut podemos inferir que, entre 2007 e 2009, houve uma pequena mas significativa alteração, quando é analisada a continuidade, por parte dos pesquisadores, dos estudos sobre futebol na passagem do mestrado para o doutorado. Os dados levantados pelo grupo revelavam que, em 2007, havia 204 dissertações de mestrado (79\%) e 54 teses de doutorado (21\%).

Não foram computados nesses valores os trabalhos produzidos por brasileiros no exterior, já que o nosso objetivo foi mapear o que foi produzido no Brasil. No quadro abaixo estão indicados o números de trabalhos realizados no mestrado e no doutorado nos últimos 20 anos.

\section{Gráfico 4 \\ Trabalhos sobre futebol realizados no mestrado e doutorado ano a ano}

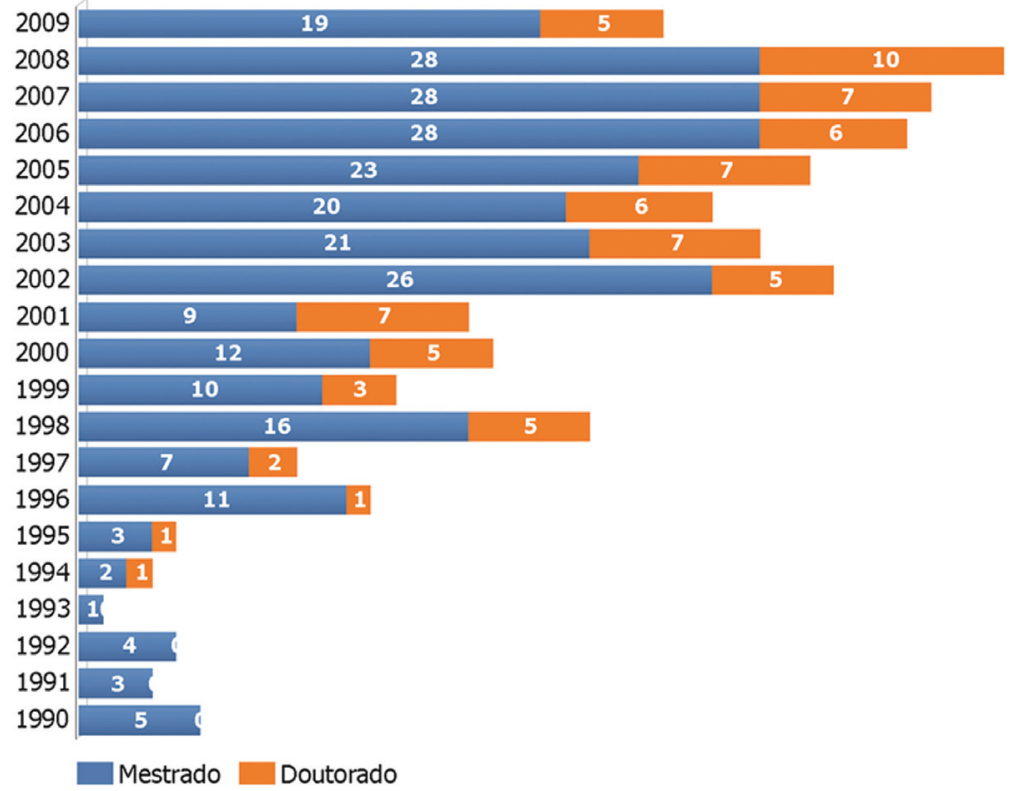

${ }^{24}$ Não estão computados nesses dados as duas livre docências, ambas da Unicamp. Conferir: Brunhs (1998) e Reis (2004). 
Ao traçar a produção ano a ano, é possível verificar que, a partir de 1990 a 1995, a produção é pequena e basicamente concentrada nas dissertações de mestrado. Em 1996, a produção triplica em relação ao ano anterior, atingindo, em 1998, a maior produção anual da década, com 22 trabalhos (o gráfico 4 não mostra os trabalhos de livre-docência, ver nota 22), número que diminuirá ao final da década, voltando a crescer em 2002, a ponto de alcançar a marca de 34 pesquisas realizadas em 2006. Esta ascensão consolida-se nos anos seguintes. O ano de 2009 representa o período de grande queda na produção em relação ao ano anterior.

\section{Tabela 3}

Produção brasileira de trabalhos de mestrado e doutorado sobre futebol por ano - 1990-2009

\begin{tabular}{rrrrrr}
\hline Ano & Total & Ano & Total & Ano & Total \\
\hline 1990 & 5 & 1997 & 9 & 2004 & 27 \\
\hline 1991 & 3 & 1998 & 22 & 2005 & 30 \\
\hline 1992 & 4 & 1999 & 13 & 2006 & 34 \\
\hline 1993 & 1 & 2000 & 17 & 2007 & 35 \\
\hline 1994 & 3 & 2001 & 16 & 2008 & 38 \\
\hline 1995 & 4 & 2002 & 31 & 2009 & 24 \\
\hline 1996 & 12 & 2003 & 28 & & \\
\hline
\end{tabular}

\section{Considerações finais}

Ao longo do artigo pudemos apresentar os dados que justificam a nossa afirmativa de que a produção sobre futebol no Brasil não é tão escassa quanto se pensa. Ressaltamos que a produção existe e que a tendência é a abertura de um maior diálogo e intercâmbio das informações, dos trabalhos produzidos e dos grupos consolidados que se propõem a discutir e a pesquisar sobre o tema. Tal intercâmbio eliminaria algumas das dificuldades encontradas para a realização deste artigo, como a desatualização de alguns currículos lattes e a demora na conferência das informações coletadas, seja no portal da Capes ou nas bibliotecas das próprias universidades, além do desencontro de algumas na disponibilização das informações, principalmente quanto ao título da pesquisa. 
É possível perceber, ainda, que a tendência é um crescimento da produção nesta próxima década. A lista dos trabalhos em andamento ${ }^{25}$ (Anexo 2 - Pesquisas em andamento) indica um aumento da demanda por doutorados, visto que quinze pesquisas de mestrado e dezesseis de doutorado serão defendidas nos próximos anos. Também teremos a conclusão do pós-doutorado, com José Paulo Florenzano, agora pela Universidade de São Paulo (USP).

Desses trabalhos em andamento, a USP lidera a lista com onze pesquisas. ${ }^{26}$ A Pontifícia Universidade Católica de São Paulo (PUC-SP) vem em seguida, com três trabalhos. Se, num primeiro momento, as pesquisas sobre futebol desenvolvidas na PUC-SP eram provenientes do núcleo liderado pela professora Márcia Regina da Costa, atualmente verifica-se que os trabalhos realizados nessa universidade provêm de outros orientadores e, portanto, de outros institutos.

Centros já estabelecidos, como o da Universidade Gama Filho e o da Universidade Federal do Paraná, continuam a produzir pesquisas (uma pesquisa cada). Devemos destacar a expansão dos trabalhos realizados pela Universidade Federal de Pernambuco - UFPE (dois trabalhos em andamento), pela Universidade Federal Fluminense - UFF (quatro trabalhos) e pela entrada da Universidade Federal de São Carlos (Ufscar) no cenário dos estudos sobre futebol, depois que Luiz Henrique de Toledo tornou-se professor da universidade, com dois trabalhos em andamento. Por fim, destacamos o aumento da produção da Universidade Federal de Minas Gerais (UFMG) que atualmente conta com Sílvio Ricardo da Silva em seu quadro docente, coordenador do Grupo de Estudos sobre Torcidas (Gefut) e responsável pela orientação de três trabalhos.

Se a produção existe e se reafirmamos a necessidade de reunir as informações e os trabalhos que se encontram dispersos, temos que destacar a preocupação das universidades brasileiras em manter bibliotecas digitais com teses e dissertações na íntegra. Para além dessas iniciativas institucionais, alguns sites foram estruturados com o objetivo de reunir esse tipo de informação. $O$ pioneiro nesse sentido foi o Centro Esportivo Virtual (CEV), ${ }^{27}$ criado em 1996, como

\footnotetext{
${ }^{25}$ Ao todo foram coletadas 36 pesquisas sobre futebol. O levantamento dos trabalhos em andamento foi mais difícil de ser realizado e sabemos que alguns pesquisadores podem ter ficado de fora da lista. Isso pode ter acontecido por dois motivos: primeiro, não conseguimos encontrar as informações pela internet e, segundo, o pesquisador não possuía o currículo lattes atualizado no momento da busca realizada por nós.

${ }^{26}$ Pode-se destacar dentre essa produção, a presença do Grupo Interdisciplinar de Estudos sobre Futebol (Gief), fundado em 2006 e que conta com parte significativa desses trabalhos e de outros que ainda serão defendidos na USP nos próximos anos.

${ }^{27} \mathrm{O}$ endereço do site é: $\underline{w w w . c e v . o r g . b r}$.
} 
parte do doutorado em Educação Física de Laércio Elias Pereira (1998), pela Universidade Estadual de Campinas. O CEV funciona a partir de comunidades temáticas no qual os inscritos em cada comunidade postam informações para compartilhar com os demais membros inscritos. Entre as seções disponíveis, existe uma biblioteca em que é possível baixar arquivos voltados ao esporte e à educação física. Neste site, o futebol é uma dentre tantas comunidades disponíveis.

Com foco específico no futebol, temos o Núcleo de Estudos Futebol e Sociedade, grupo acadêmico de estudos e pesquisas interdisciplinar, organizado a partir da Pós-Graduação em História da Universidade Federal do Paraná e coordenado por Luiz Carlos Ribeiro. O Núcleo mantém um site, Futebol e Sociedade, ${ }^{28}$ com o objetivo de reunir uma série de informações sobre o futebol. Possui uma biblioteca digital em que é possível encontrar, acessar e imprimir teses, dissertações e artigos acadêmicos.

O site Ludopédio, ${ }^{29}$ formado por alguns integrantes do Grupo Interdisciplinar de Estudos sobre Futebol (Gief), também tem como proposta reunir em um mesmo local diferentes tipos de produções sobre futebol (referências de livros e filmes, arquivos de teses/dissertações, artigos, monografias), disponíveis para acesso na seção Biblioteca. Assim, tanto o Ludopédio quanto os outros sites acima mencionados facilitarão o desenvolvimento de futuros trabalhos de pesquisa e atualização dos mapeamentos sobre a produção. Por fim, ao apresentar as informações contidas nesse artigo, deixamos como desafio para os pesquisadores aquilo que consideramos fundamental em um mapeamento: a atualização das informações para que assim possam auxiliar os pesquisadores no desenvolvimento de suas investigações.

\section{Referências bibliográficas}

ALABARCES, Pablo. Veinte años de ciencias sociales y deporte em América Latina: un balance, una agenda. Revista Brasileira de Informação Bibliográfica em Ciências Sociais. São Paulo, v. 58, 2004, p. 159-179.

ALABARCES, Pablo. A pesquisa argentina: um mapa, uma agenda. In: RIBEIRO, Luiz (org.). Futebol e globalização. Jundiaí: Fontoura, 2007.

ALABARCES, Pablo. Homenaje a un fundador: Eduardo Archetti. Horizontes Antropológicos. Porto Alegre, v. 14, n. 30, dez. 2008, p. 255-257.

ANTUNES, Fatima M. R. F. Anarquistas e comunistas no futebol de São Paulo. $D$. O. Leitura. São Paulo, v. 127, 1992, p. 2-3.

${ }^{28} \mathrm{O}$ endereço do site é: $\underline{w w w . f u t e b o l e s o c i e d a d e . c o m . b r . ~}$

${ }^{29} \mathrm{O}$ endereço do site é: www.ludopedio.com.br. 
ANTUNES, Fatima M. R. F. O futebol nas fábricas. Revista USP -Dossiê Futebol. São Paulo, n. 22, 1994, p. 102-109.

ARAUJO, Ricardo A. B. de. Os gênios da pelota: um estudo do futebol como profissão. Dissertação de Mestrado em Antropologia Social, Museu Nacional/PPGAS, Universidade Federal do Rio de Janeiro, Rio de Janeiro, 1980.

ARCHETTI, Eduardo. El potrero y el pibe: territorio y pertenencia en el imaginario del fútbol argentino. Revista Nueva Sociedad, n. 154, 1998, p. 101-119.

ARCHETTI, Eduardo. Transforming Argentina: sport, modernity and national building in the periphery. Antropolítica. Niterói, n. 14, 2003, p. 41-60.

ARCHETTI, Eduardo. El potrero y el pibe: territorio y pertenencia en el imaginario del fútbol argentino. Horizontes Antropológicos. Porto Alegre, v. 14, n. 30, dez. 2008, p. 259-282.

BROMBERGER, Christian. As práticas e os espetáculos esportivos na perspectiva da etnologia. Horizontes Antropológicos. Porto Alegre, v. 14, n. 30, dez. 2008, p. 237-253.

BRUHNS, Heloisa T. Futebol, carnaval e capoeira: a transição entre os grupos sociais. Tese de Livre Docência, Faculdade de Educação Física, Universidade Estadual de Campinas, 1998, $154 \mathrm{f}$.

BRUNI, José C. Apresentação. Revista USP - Dossiê Futebol. São Paulo, n. 22, 1994, p. 6-9. Tese de Livre Docência em Educação Física, Faculdade de Educação Física, Universidade Estadual de Campinas, 1998.

CALDAS, Waldenyr. O futebol no país do futebol. Lua Nova. São Paulo, v. 3, n. 10, out./dez. 1986.

CALDAS, Waldenyr. Os cartolas são inevitáveis? Entrevista de Walter Casagrande a Waldenyr Caldas. Lua Nova. São Paulo, v. 3, n. 10, out./dez. 1986.

CALDAS, Waldenyr. O pontapé inicial: memória do futebol brasileiro (1894-1933). São Paulo: Ibrasa, 1990.

CALDAS, Waldenyr. Aspectos sociopolíticos do futebol brasileiro. Revista USP Dossiê Futebol. São Paulo, n. 22, 1994, p. 40-49.

CAMPOS, Maria C. C. Futebol e relações de gênero em Maracanã, adeus. Pesquisa de Campo. Rio de Janeiro, n. 0, 1994, p. 53-59.

COSTA, Francisco. A bola na ponta da caneta. Revista USP - Dossiê Futebol. São Paulo, n. 22, 1994, p. 84-91.

COUTINHO, Edilberto. Zelins, Flamengo até morrer. Pesquisa de Campo. Rio de Janeiro, n. 0, 1994, p. 27-37.

DAMATTA, Roberto (org.). Universo do futebol: esporte e sociedade brasileira. Rio de Janeiro: Pinakotheke, 1982a.

DAMATTA, Roberto. Futebol: ópio do povo x drama de justiça social. Novos Estudos. São Paulo, v. 1, n. 4, nov. 1982.

DAMATTA, Roberto. Antropologia do óbvio. Revista USP - Dossiê Futebol. São 
Paulo, n. 22, 1994, p. 10-17.

DAMATTA, Roberto. Brasil: futebol tetracampeão do mundo (entrevista). Pesquisa de Campo. Rio de Janeiro, n. 1, 1995, p. 7-12.

DAMATTA, Roberto. Em torno da dialética entre igualdade e hierarquia: notas sobre as imagens e representações dos Jogos Olímpicos e do futebol no Brasil. Antropolítica. Niterói, n. 14, 2003, p. 17-39.

DAMO, Arlei S. Para o que der e vier: o pertencimento clubístico no futebol brasileiro a partir do Grêmio Futebol Porto Alegrense e seus torcedores. Dissertação de Mestrado em Antropologia Social, Instituto de Filosofia e Ciências Humanas, Universidade Federal do Rio Grande do Sul, Porto Alegre, 1998, $237 \mathrm{f}$.

DAMO, Arlei S. Ah! Eu sou gaúcho: o nacional e o regional no futebol brasileiro. Estudos Históricos. Rio de Janeiro, v. 1, n. 23, 1999, p. 87-118.

DAMO, Arlei S. Do dom à profissão: uma etnografia do futebol de espetáculo a partir da formação de jogadores no Brasil e na França. 2005. Tese de Doutorado em Antropologia Social, Instituto de Filosofia e Ciências Humanas, Universidade Federal do Rio Grande do Sul, Porto Alegre, 2005, 435 f.

DAMO, Arlei S. Senso de jogo. Esporte e Sociedade. Rio de Janeiro, n. 1, nov./2005fev./2006.

DAMO, Arlei S. Dom, amor e dinheiro no futebol de espetáculo. Revista Brasileira de Ciências Sociais. São Paulo, v. 23, n. 66, 2008, p. 139-150.

DUNNING, Eric. Sobre problemas de identidade e emoções no esporte e no lazer: comentários críticos e contracríticos sobre as sociologias convencional e configuracional de esporte e lazer. História: Questões \& Debates. Curitiba, n. 39, 2003, p. 11-40.

FARIA JUNIOR, Alfredo G. de. Futebol, questões de gênero e coeducação. Pesquisa de Campo. Rio de Janeiro, n. 2, 1995, p. 17-39.

FEIJÓ, Luiz C. S. À altura dos pergaminhos. Pesquisa de Campo. Rio de Janeiro, n. 2, 1995, p. 59-69.

FEIJÓ, Luiz C. S. Desvios linguísticos e pressões contextuais na linguagem especial do futebol em Portugal. Pesquisa de Campo. Rio de Janeiro, n. 5, 1997, p. 35-43.

FERREIRA, Ana L. P. O estado da arte da sociologia do esporte no Brasil: um mapeamento da produção bibliográfica de 1997 a 2007. Dissertação de Mestrado em Sociologia, Departamento de Ciências Sociais, Universidade Federal do Paraná, Curitiba, 2009, 269 f.

FLORES, Luiz F. B. N. Da construção do conceito de violência. Pesquisa de Campo. Rio de Janeiro, n. 2, 1995, p. 7-16.

FRYDENBERG, Julio D. Boca Juniors em Europa: el diário crítico y el primer nacionalismo deportivo argentino. História: Questões \& Debates. Curitiba, n. 39, 2003, p. 91-120.

GASTALDO, Edison. Um tempo para jogar: o "ser brasileiro" na publicidade da Copa do Mundo. Campos - Revista de Antropologia da UFPR. Curitiba, v. 1, 
n. 1, 2001, p. 123-146.

GASTALDO, Edison. Negros jogam, brancos torcem: a ritualização das relações raciais na publicidade da Copa do Mundo. Ilha - Revista de Antropologia (Florianópolis). Florianópolis, v. 4, 2002, p. 99-110.

GASTALDO, Edison. O complô da torcida: futebol e performance masculina em bares. Horizontes Antropológicos. Porto Alegre, v. 11, n. 24, dez. 2005, p. 107-123.

GASTALDO, Edison. Crônicas da pátria amada: futebol e identidades brasileiras na imprensa esportiva. Antropolítica. Niterói, n. 19, p. 147-163, 2006 a.

GASTALDO, Edison. Futebol e sociabilidade: apontamentos sobre as relações jocosas futebolísticas. Esporte e Sociedade. Rio de Janeiro, n. 3, jul./2006-out./2006b.

GASTALDO, Edison. Esporte, violência e civilização: uma entrevista com Eric Dunning. Horizontes Antropológicos. Porto Alegre, v. 14, n. 30, dez. 2008, p. 223-231.

GASTALDO, Edison. O "país do futebol” mediatizado: mídia e Copa do Mundo no Brasil. Sociologias. Porto Alegre, v. 22, 2009, p. 352-369.

GEFUT. Levantamento da produção acadêmica acerca do futebol nas ciências humanas e sociais (1980-2007). 2009. UFMG, Ministério do Esporte. CD-ROM (1 disco).

GORDON JUNIOR, Cesar C. História social dos negros no futebol brasileiro. Pesquisa de Campo. Rio de Janeiro, n. 2, 1995, p. 71-90.

GORDON JUNIOR, Cesar C. "Eu já fui preto e sei o que é isso". História social dos negros no futebol brasileiro: segundo tempo. Pesquisa de Campo. Rio de Janeiro, n. 3/4, 1996, p. 71-90.

GUEDES, Simoni L. O futebol brasileiro: instituição zero. Dissertação de Mestrado em Antropologia Social, Museu Nacional/PPGAS, Universidade Federal do Rio de Janeiro, Rio de Janeiro, 1977.

GUEDES, Simoni L. O salvador da pátria: considerações em torno da imagem do jogador Romário na Copa do Mundo de 1994. Pesquisa de Campo. Rio de Janeiro, n. 1, 1995, p. 23-41.

GUEDES, Simoni L. Esporte e modernidade: apresentação. Antropolítica. Niterói, n. 14,2003 , p. 11-16.

GIULIANOTTI, Richard. Globalização cultural nas fronteiras: o caso do futebol escocês. História: Questões \& Debates. Curitiba, n. 39, 2003, p. 41-64.

GUIMARÃES, Manuel L. L. S. Futebol, sonho e decepção (resenha). Estudos Históricos. Rio de Janeiro, v. 1, n. 23, 1999, p. 209-213.

HELAL, Ronaldo; GORDON JUNIOR, Cesar. Sociologia, história e romance na construção da identidade nacional através do futebol. Estudos Históricos. Rio de Janeiro, v. 1, n. 23, 1999, p. 147-166.

HELAL, Ronaldo; COELHO, Maria C. Modernidade e tradição no futebol brasileiro: o "caso Bebeto". Pesquisa de Campo. Rio de Janeiro, n. 2, 1995, p. 91-99. 
LEITE LOPES, José S. A vitória do futebol que incorporou a pelada. Revista USP - Dossiê Futebol. São Paulo, n. 22, 1994, p. 64-83.

LEITE LOPES, José S. Esporte, emoção e conflito social. Mana: Estudos de Antropologia Social. Rio de Janeiro, v. 1, 1995, p. 141-166.

LEITE LOPES, José S. Considerações em torno das transformações do profissionalismo no futebol a partir da observação da Copa de 1998. Estudos Históricos. Rio de Janeiro, v. 1, n. 23, 1999, p. 170-190.

LEMOS, Maria T. T. B. Tlachtli - o jogo de bola na Meso-América. Pesquisa de Campo. Rio de Janeiro, n. 1, 1995, p. 55-62.

LIMONGI, Fernando. Revista Sociologia: a ELSP e o desenvolvimento da sociologia em São Paulo. In: Caderno Idesp, 1 (série: História das Ciências Sociais), 1987.

LIZÁRRAGA, Antônio. Anatomia do gol. Revista USP - Dossiê Futebol. São Paulo, n. 22, 1994, p. 50-63.

MAIA, Eline D. Esporte e juventude no Borel. Estudos Históricos. Rio de Janeiro, v. 1, n. 23, 1999, p. 192-206.

MEIHY, José C. S.; WITTER, José S. (orgs.). Futebol e cultura: coletâneas de estudos. São Paulo: Imprensa Oficial, Arquivo do Estado, 1982.

MURAD, Maurício. Saldanha, uma saudade. Pesquisa de Campo. Rio de Janeiro, n. 0, 1994, p. 7-25.

MURAD, Maurício. Futebol e violência no Brasil. Pesquisa de Campo. Rio de Janeiro, n. 3/4, 1996, p. 89-103.

MURAD, Maurício. Núcleo de Sociologia do Futebol - UERJ. Estudos Históricos. Rio de Janeiro, v. 1, n. 23, 1999a, p. 207-208.

MURAD, Maurício. Considerações possíveis de uma resposta necessária. Estudos Históricos. Rio de Janeiro, v. 2, n. 24, 1999b, p. 431-446.

MURAD, Maurício. Entrevista com Mauricio Murad. Ludopédio, online. São Paulo, 2010. Disponível: http://www.ludopedio.com.br/rc/index.php/entrevistas/ artigo/184. Acesso em: 15/01/2010.

NEGREIROS, Plínio J. L. de C. Futebol nos anos 1930 e 1940: construindo a identidade nacional. História: Questões \& Debates. Curitiba, n. 39, 2003, p. 121-151.

PACHECO; Ana J. P.; CUNHA JUNIOR, Carlos F. F. da. Jogos Olímpicos de Atlanta 1996: a imprensa e o "futebol de saias" do Brasil. Pesquisa de Campo. Rio de Janeiro, n. 5, 1997, p. 95-108.

PEREIRA, Laércio E. Centro esportivo virtual: um recurso de informação em educação física e esportes na internet. Tese de Doutorado em Educação Física, Faculdade de Educação Física, Universidade Estadual de Campinas, Campinas, 1998, 90 f.

PINTO, Luiz A. C. Resenha do livro O negro no futebol brasileiro. Sociologia. São Paulo, v. IX, n. 2, 1947, p. 181-184.

PRADO, Décio de A. Décio de Almeida Prado: dois textos. Revista USP - Dossiê Futebol. São Paulo, n. 22, 1994, p. 18-29. 
REIS, Heloisa H. B. dos. A violência nos estádios: um estudo comparado entre Brasil e Espanha. Tese de Livre Docência, Faculdade de Educação Física, Universidade Estadual de Campinas, 2004.

RIAL, Carmen S. M. Futebol e mídia: a retórica televisiva e suas implicações na identidade nacional, de gênero e religiosa. Antropolítica. Niterói, n. 14, 2003, p. 61-80.

RIAL, Carmen S. M. Rodar: a circulação dos jogadores de futebol brasileiros no exterior. Horizontes Antropológicos. Porto Alegre, v. 14, n. 30, dez. 2008, p. 21-65.

ROCHA, Everardo. As invenções do cotidiano: o descobrimento do Brasil e a conquista do tetra. Pesquisa de Campo. Rio de Janeiro, n. 2, 1995, p. 41-57.

ROCHA, Everardo. As invenções do cotidiano: o descobrimento do Brasil e a conquista do tetra (parte 2). Pesquisa de Campo. Rio de Janeiro, n. 3/4, 1996, p. 9-20.

RODRIGUES FILHO, Nelson. Lima Barreto: jogando contra o futebol. Pesquisa de Campo. Rio de Janeiro, n. 1, 1995, p. 43-53.

ROSA, Mário M. O papel da magia no futebol. Sociologia. São Paulo, v. VI, n. 4, 1944, p. 295-304.

ROSENFELD, Anatol. O futebol no Brasil. In: Argumento, n. 2. Rio de Janeiro: Paz e Terra, 1974.

SEVCENKO, Nicolau. Futebol, metrópole e desatinos. Revista USP - Dossiê Futebol. São Paulo, n. 22, 1994, p. 30-37.

SOARES, Antonio J. Futebol, raça e nacionalidade: releitura da história oficial. Tese de Doutorado em Educação Física, Faculdade de Educação Física, Universidade Gama Filho, Rio de Janeiro, 1998.

SOARES, Antonio J. História e a invenção das tradições no campo de futebol. Estudos Históricos. Rio de Janeiro, v. 1, n. 23, 1999a, p. 119-146.

SOARES, Antonio J. A modo de resposta. Estudos Históricos. Rio de Janeiro, v. 1, n. 23, 1999b, p. 167-174.

SOARES, Antonio J.; LOVISOLO, Hugo R. O futebol é fogo de palha: a "profecia" de Graciliano Ramos. Pesquisa de Campo. Rio de Janeiro, n. 5, 1997, p. 7-20.

SOUZA, Candice V. de. A Folha de S.Paulo e o "país do futebol": narrativas jornalísticas da nação e o debate de 1997 sobre o futebol brasileiro. História: Questões \& Debates. Curitiba, n. 39, 2003, p. 65-90.

TOLEDO, Luiz H. Por que xingam os torcedores de futebol? Cadernos de Campo. São Paulo, n. 3, 1993, p. 20-29.

TOLEDO, Luiz H. Transgressão e violência entre torcedores de futebol. Revista USP - Dossiê Futebol. São Paulo, n. 22, 1994, p. 92-101.

TOLEDO, Luiz H. Torcidas organizadas de futebol: lazer e estilo de vida na metrópole. Dissertação de Mestrado em Antropologia Social, Faculdade de Filosofia, Letras e Ciências Sociais, Universidade de São Paulo, São Paulo, 1994.

TOLEDO, Luiz H. Contribuições ao estudo da crônica esportiva 1: "contracrônica" 
esportiva de Lima Barreto. Pesquisa de Campo. Rio de Janeiro, n. 3/4, 1996, p. 37-50.

TOLEDO, Luiz H. Futebol e teoria social: aspectos da produção acadêmica brasileira (1982-2002). Revista Brasileira de Informação Bibliográfica em Ciências Sociais. São Paulo, v. 52, 2001, p. 133-165.

TOLEDO, Luiz H. Jogo livre: analogias em torno das 17 regras do futebol. Horizontes Antropológicos. Porto Alegre, v. 14, n. 30, dez. 2008, p. 191-219.

TONELLI, Nicélio C. A arqueologia do "futebol" maia: o jogo da pelota. Pesquisa de Campo. Rio de Janeiro, n. 5, 1997, p. 21-34.

Recebido: 17/12/2009 - Aprovado: 24/05/2010 


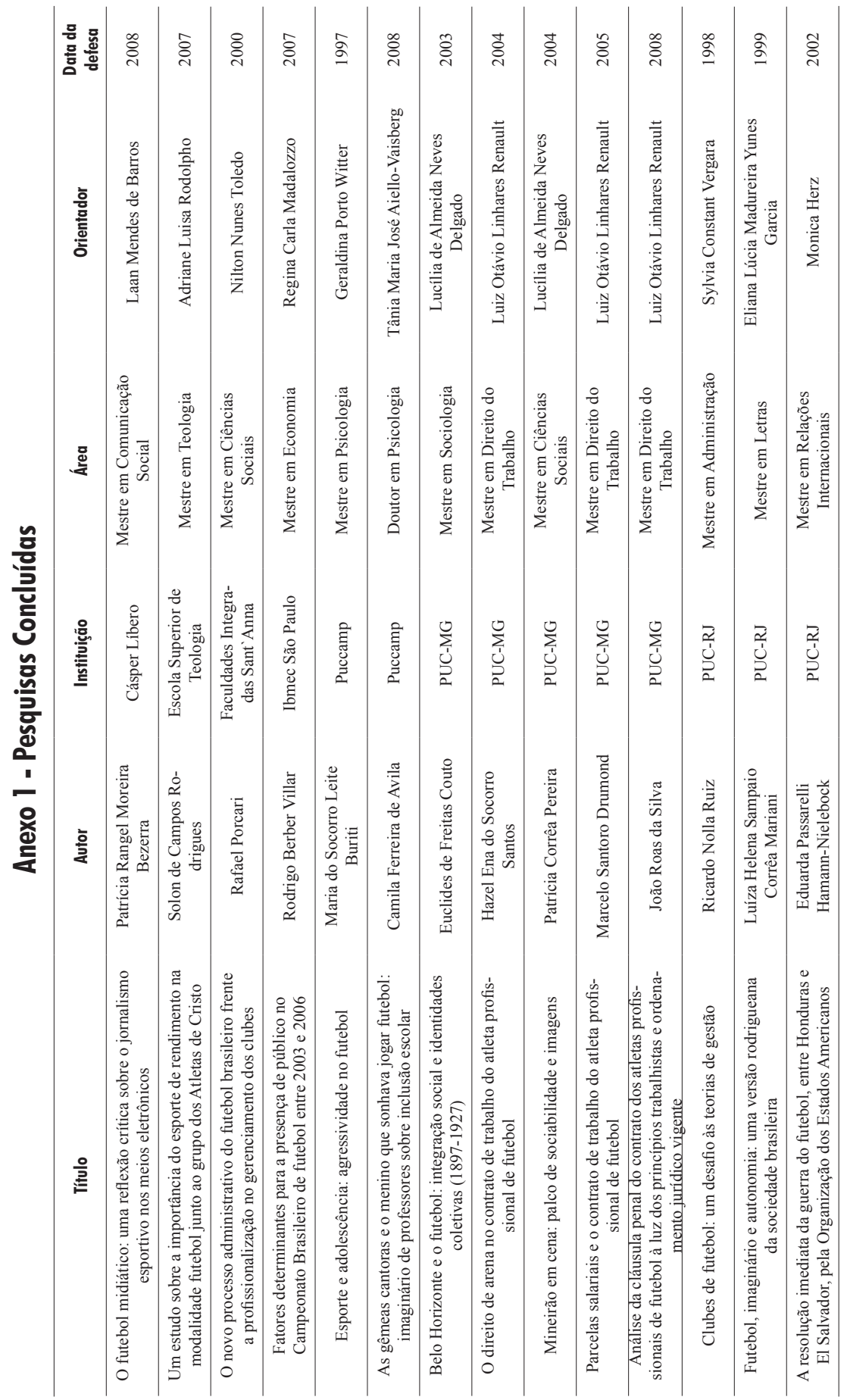




\begin{tabular}{|c|c|c|c|c|c|c|c|c|c|c|c|c|c|c|c|}
\hline 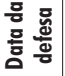 & 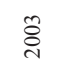 & ¿ัن & $\stackrel{\text { ¿े }}{\infty}$ & 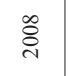 & ळे & बे & $\overline{\mathrm{d}}$ & ઠิे & ¿े & ¿े & ¿े & کे & $\stackrel{\alpha}{\sigma}$ & よ̊ & $\alpha$ \\
\hline 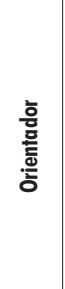 & 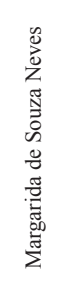 & 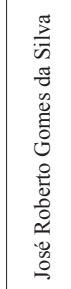 & 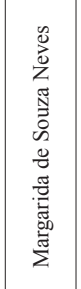 & 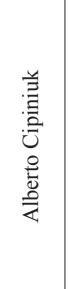 & 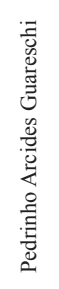 & $\begin{array}{l}0 \\
0 \\
.5 \\
0 \\
0 \\
0 \\
0 \\
0 \\
0 \\
0 \\
0 \\
0 \\
0 \\
0 \\
0 \\
0\end{array}$ & $\begin{array}{l}0 \\
\frac{0}{0} \\
\frac{0}{0} \\
0 \\
0 \\
\frac{0}{0} \\
\stackrel{0}{0} \\
0 \\
0\end{array}$ & 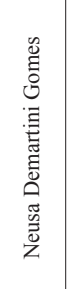 & 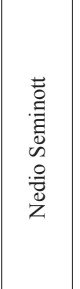 & 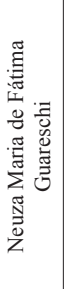 & 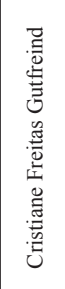 & 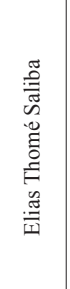 & 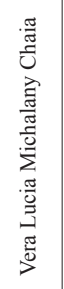 & 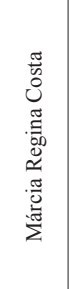 & 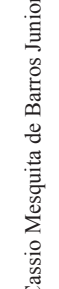 \\
\hline 离 & 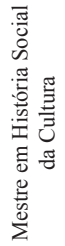 & 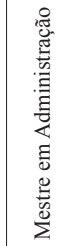 & 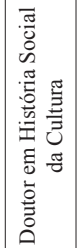 & 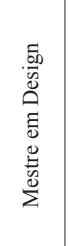 & 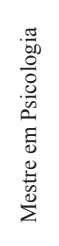 & 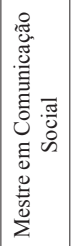 & 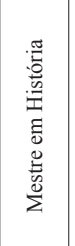 & 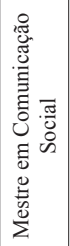 & 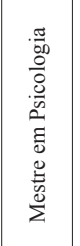 & 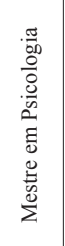 & 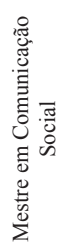 & 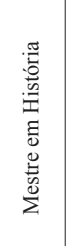 & 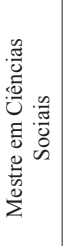 & 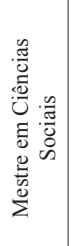 & $\bar{z}$ \\
\hline 总 & $\begin{array}{l}\stackrel{2}{U^{\prime}} \\
\text { D. }\end{array}$ & 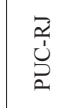 & $\begin{array}{l}\overrightarrow{2} \\
\text { U. } \\
\text { 2. }\end{array}$ & $\begin{array}{l}\overrightarrow{2} \\
\text { 今. } \\
\text { D. }\end{array}$ & 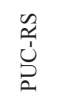 & 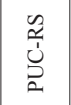 & 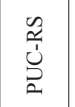 & 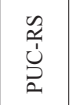 & 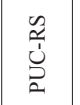 & 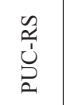 & 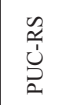 & $\begin{array}{l}\text { जि } \\
\text { 仓̊ } \\
\text { D. }\end{array}$ & $\begin{array}{l}\text { जे } \\
\text { 仓ે } \\
\text { D. }\end{array}$ & $\begin{array}{l}\text { जि } \\
\text { Uీ } \\
\text { D. }\end{array}$ & \\
\hline 产 & 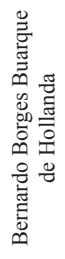 & 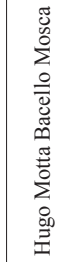 & 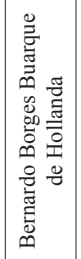 & 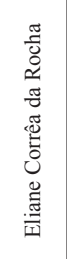 & 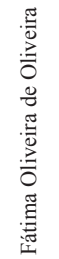 & 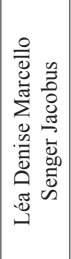 & 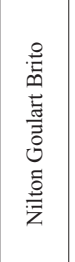 & 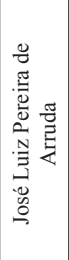 & 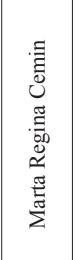 & 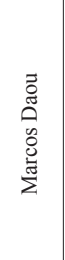 & 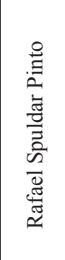 & 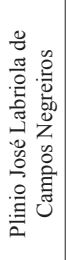 & 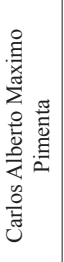 & 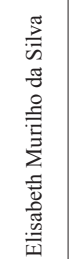 & $\begin{array}{l}\text { 品 } \\
\text {. } \\
\text { 音 }\end{array}$ \\
\hline 을 & 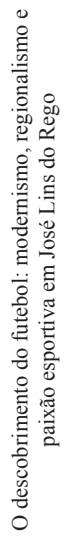 & 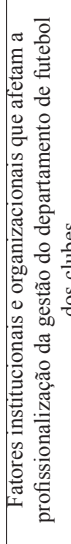 & 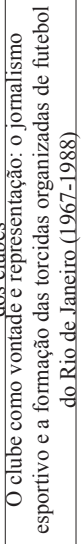 & 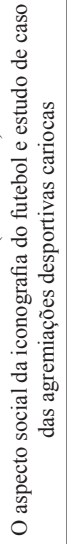 & 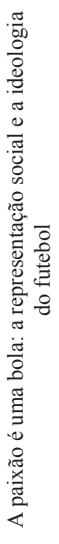 & 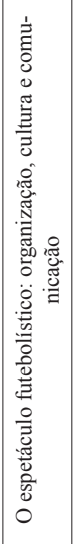 & 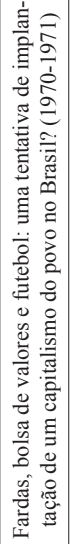 & 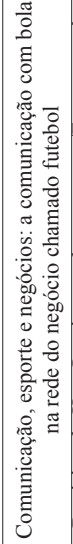 & 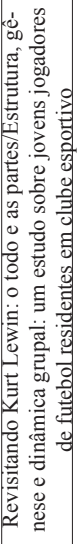 & 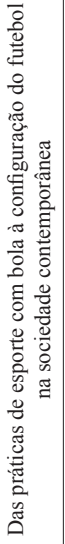 & 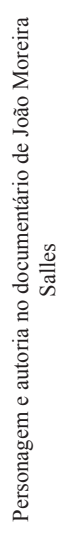 & 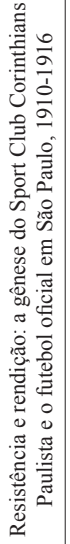 & 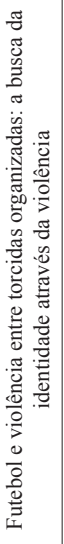 & 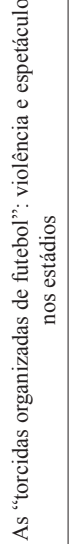 & 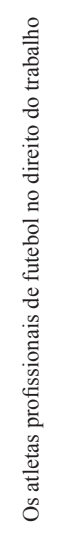 \\
\hline
\end{tabular}




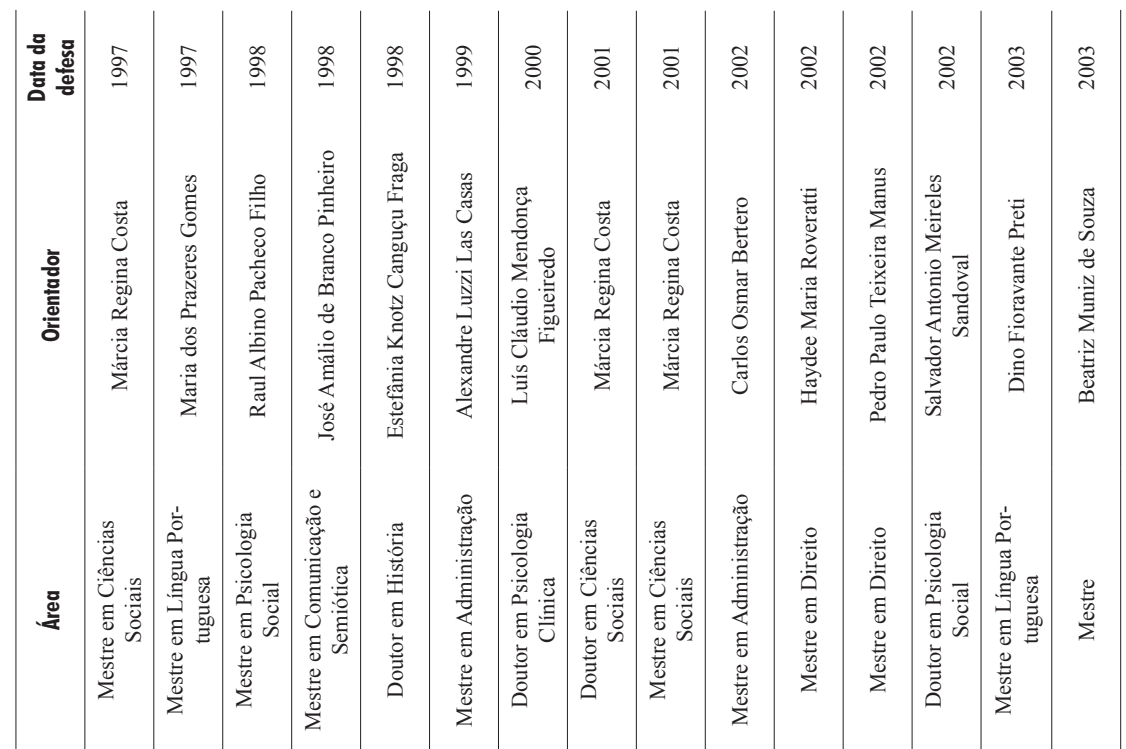

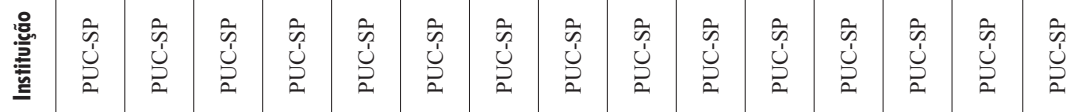

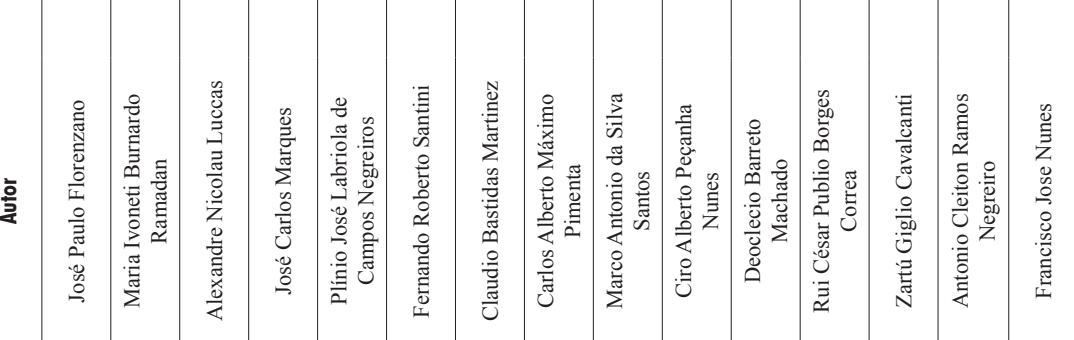

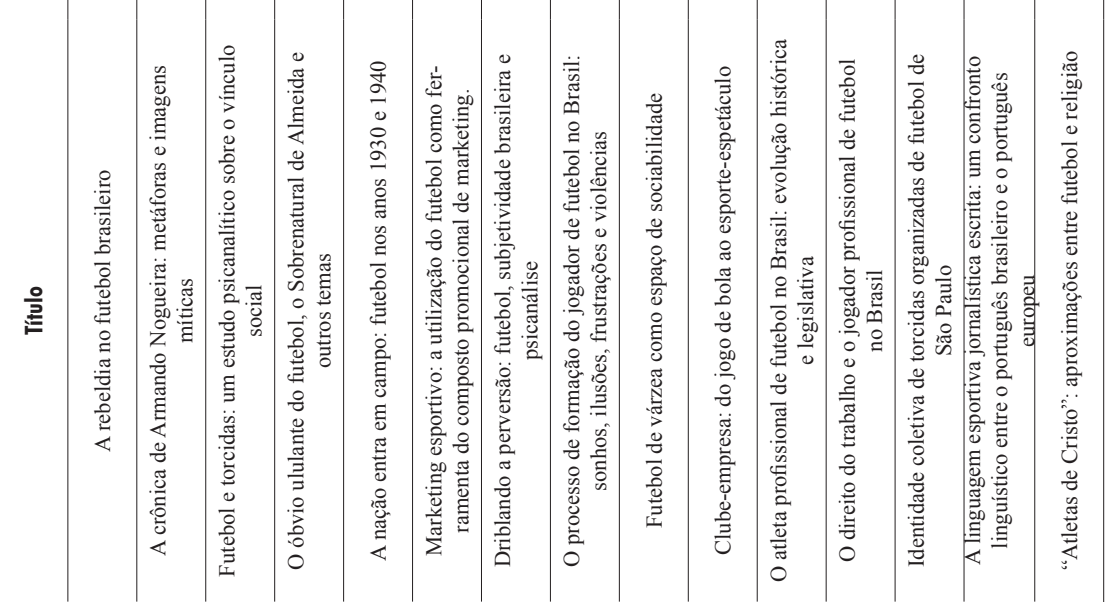




\begin{tabular}{|c|c|c|c|c|c|c|c|c|c|c|c|c|c|c|c|}
\hline $\begin{array}{l}\text { 등 명 } \\
\text { 흠 }\end{array}$ & ڤ్రి & ڤ్ & ષ્ণ & 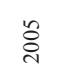 & ๕్ ڤ్ & ¿્ণ & ๕ั & $\widehat{\stackrel{े}{े}}$ & $\widehat{\stackrel{े}{े}}$ & $\stackrel{\infty}{\stackrel{\infty}{\sim}}$ & $\stackrel{\text { ¿̊ }}{\circ}$ & ¿্ণి & ڤ્ণે & ڤ્ণે & ઠેेે \\
\hline $\begin{array}{l}\text { 흠 } \\
\text { 홓 } \\
\text { 힣 }\end{array}$ & 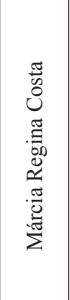 & 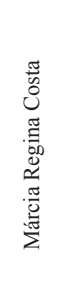 & 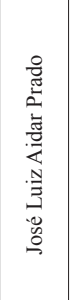 & 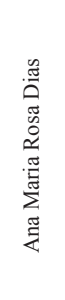 & 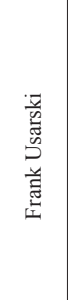 & 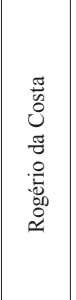 & $\begin{array}{l}\frac{\pi}{0} \\
\ddots \\
0 \\
\frac{8}{0} \\
0 \\
0 \\
0 \\
0 \\
0 \\
0\end{array}$ & 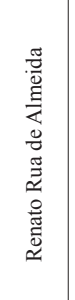 & 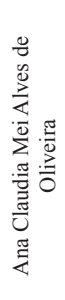 & 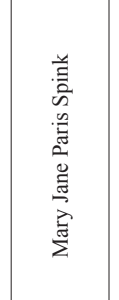 & 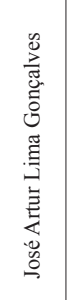 & 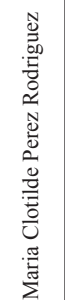 & 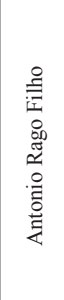 & 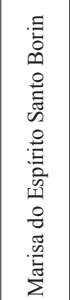 & 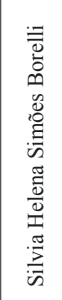 \\
\hline 龸 & 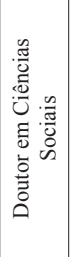 & 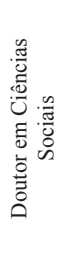 & 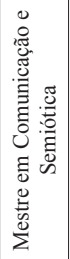 & 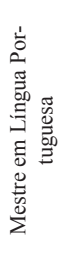 & 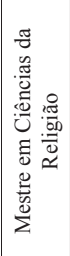 & 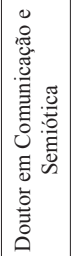 & 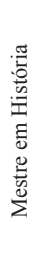 & 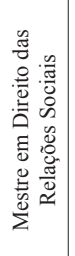 & 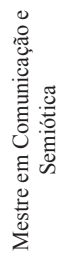 & 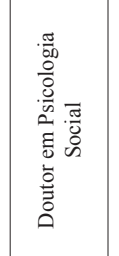 & 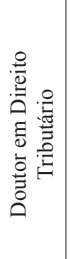 & 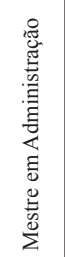 & 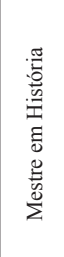 & 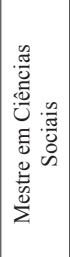 & 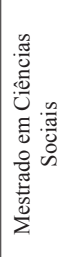 \\
\hline 总 & 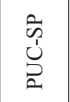 & 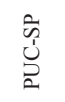 & $\begin{array}{l}\text { जे } \\
\text { 仓े } \\
\text { 2. }\end{array}$ & 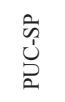 & $\begin{array}{l}\text { जि } \\
\text { 仓ે } \\
\text { ¿ }\end{array}$ & $\begin{array}{l}\text { जि } \\
\text { 仓் } \\
\text { D. }\end{array}$ & $\begin{array}{l}\text { के } \\
\text { 仓े } \\
\text { 2. }\end{array}$ & 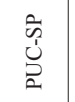 & $\begin{array}{l}\text { 菑 } \\
\text { : } \\
\text { : }\end{array}$ & 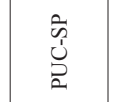 & 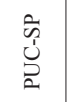 & $\begin{array}{l}\tilde{\hat{⿱}} \\
\hat{1} \\
\underline{2}\end{array}$ & $\begin{array}{l}\overrightarrow{\hat{n}} \\
\text { i⿱ } \\
\text { D. }\end{array}$ & $\begin{array}{l}\text { क् } \\
\text { 仓் } \\
\text { D. }\end{array}$ & 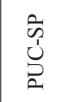 \\
\hline 혼 & 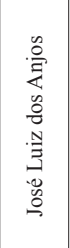 & 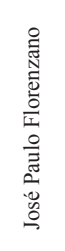 & 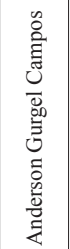 & 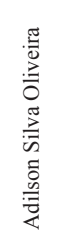 & 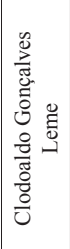 & 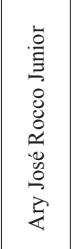 & 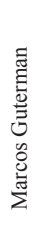 & 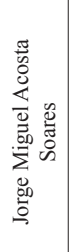 & 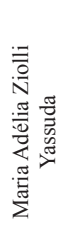 & 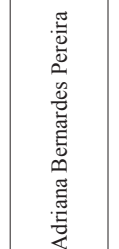 & 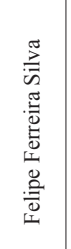 & 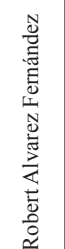 & 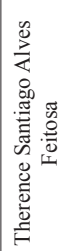 & 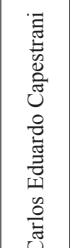 & 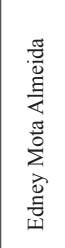 \\
\hline 을 & 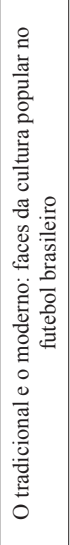 & 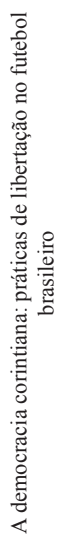 & 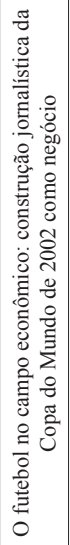 & 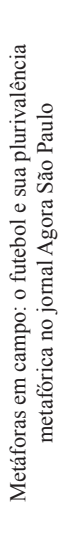 & 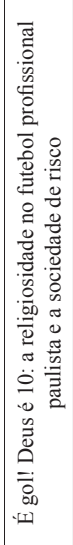 & 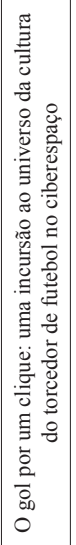 & 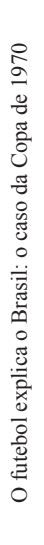 & 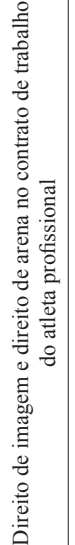 & 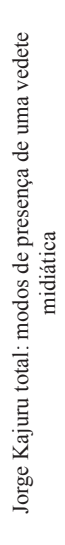 & 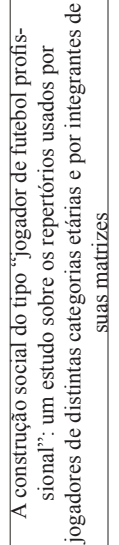 & 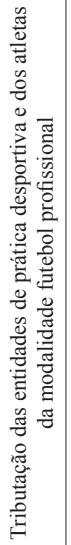 & 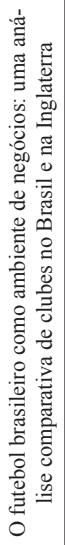 & 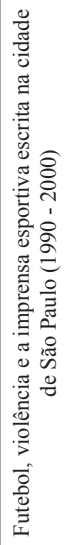 & 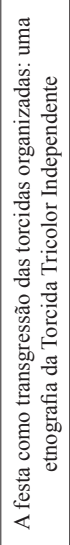 & 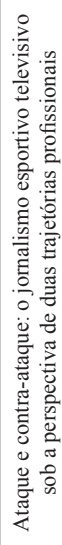 \\
\hline
\end{tabular}




\begin{tabular}{|c|c|c|c|c|c|c|c|c|c|c|c|c|c|c|c|}
\hline 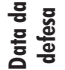 & ڤे & હें & ڤ્సે & ષ્స & 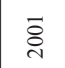 & ષ્స & હे & $\stackrel{\infty}{\circ}$ & $\stackrel{\sim}{\text { ¿ }}$ & ङ్ & ¿्તે & ¿्రి & ڤ్ & ષ્సે & ¿্సి \\
\hline $\begin{array}{l}\frac{\text { 흠 }}{\bar{t}} \\
\text { 흫 }\end{array}$ & 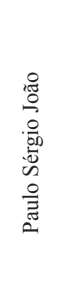 & 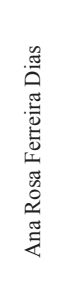 & 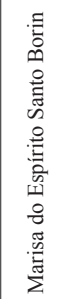 & 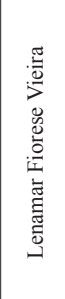 & 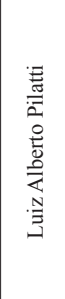 & 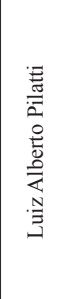 & 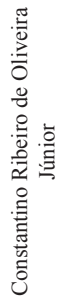 & 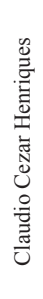 & 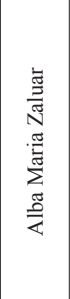 & 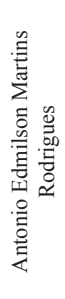 & 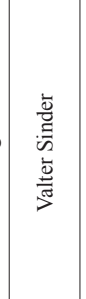 & 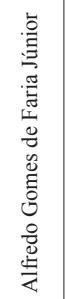 & 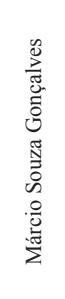 & 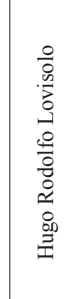 & 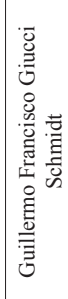 \\
\hline 焉 & 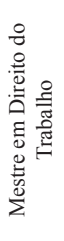 & 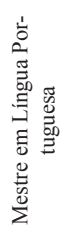 & 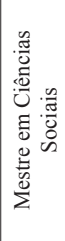 & 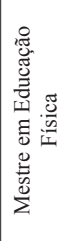 & 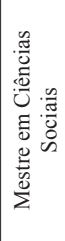 & 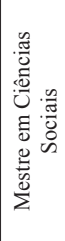 & 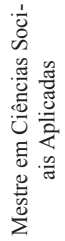 & 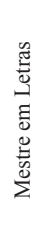 & 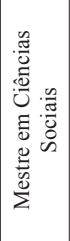 & 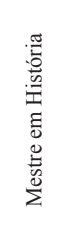 & 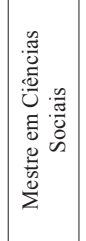 & 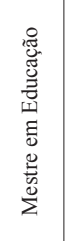 & 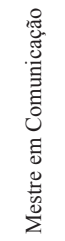 & 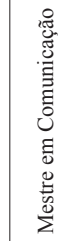 & 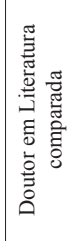 \\
\hline 总 & $\begin{array}{l}\vec{w} \\
\text { 仓े } \\
\text { D. }\end{array}$ & 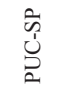 & $\begin{array}{l}\overrightarrow{\hat{n}} \\
\text { 仓े } \\
\text { : }\end{array}$ & $\underset{\text { 至 }}{\Sigma}$ & $\begin{array}{l}0 \\
\text { D } \\
\text { |ᄑ }\end{array}$ & 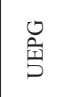 & 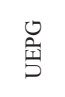 & $\begin{array}{l}\overrightarrow{2} \\
\text { IS }\end{array}$ & $\begin{array}{l}\overrightarrow{2} \\
\text { 兵 }\end{array}$ & $\frac{\overrightarrow{2}}{5}$ & $\begin{array}{l}\overrightarrow{2} \\
\text { I5 }\end{array}$ & $\begin{array}{l}\overrightarrow{\widetilde{Y}} \\
\mathrm{~s}\end{array}$ & $\frac{\overrightarrow{2}}{\text { M }}$ & $\begin{array}{l}\frac{\overrightarrow{2}}{5} \\
\frac{5}{5}\end{array}$ & $\frac{\overrightarrow{2}}{5}$ \\
\hline$\stackrel{\frac{0}{3}}{\frac{3}{2}}$ & 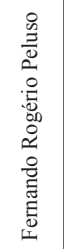 & 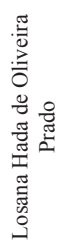 & 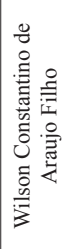 & 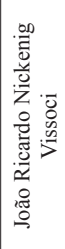 & 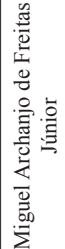 & 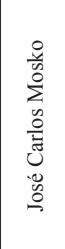 & 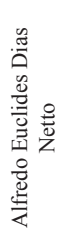 & 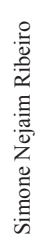 & 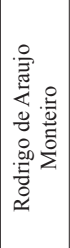 & 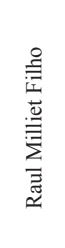 & 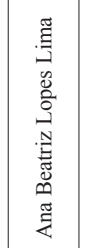 & 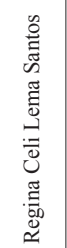 & 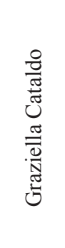 & 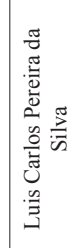 & 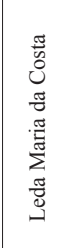 \\
\hline 을 & 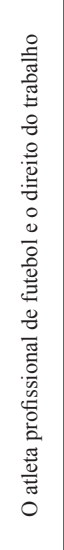 & 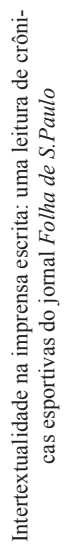 & 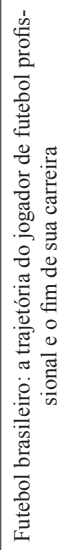 & 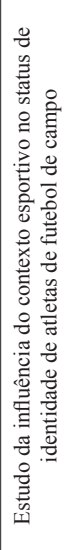 & 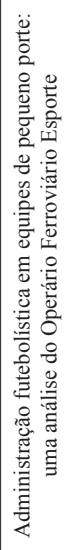 & 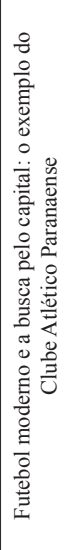 & 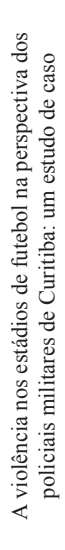 & 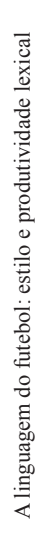 & 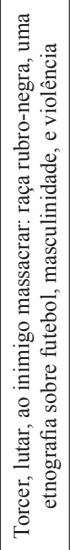 & 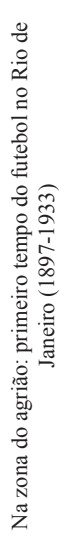 & 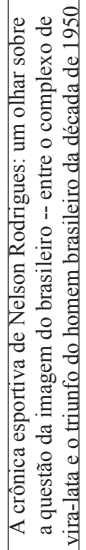 & 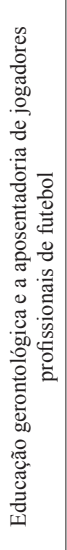 & 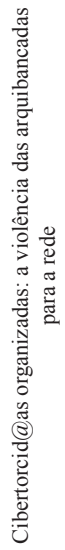 & 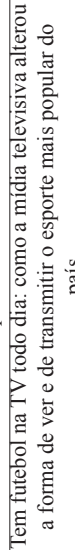 & 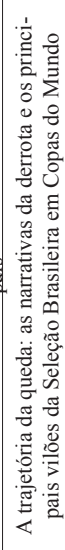 \\
\hline
\end{tabular}




\begin{tabular}{|c|c|c|c|c|c|c|c|c|c|c|c|c|c|c|c|}
\hline 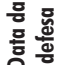 & હ্ণ & હે & ષ્సి & હ્సి & ¿ें & ¿্రి & ¿্ & ஓ્స & ¿্రి & ¿্ণ & ¿्रे & ¿্రి & ¿্ণ & ¿্. & ¿े \\
\hline 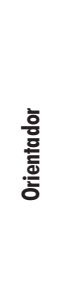 & 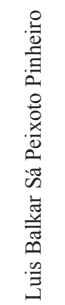 & 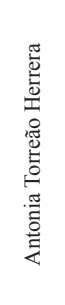 & 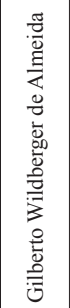 & 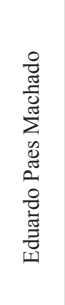 & 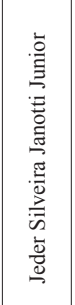 & 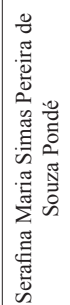 & 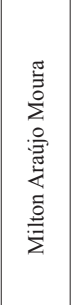 & 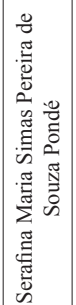 & 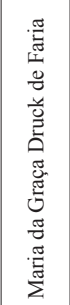 & 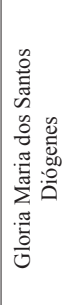 & 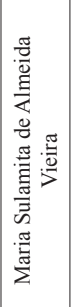 & 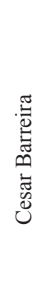 & 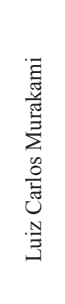 & 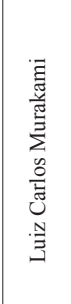 & 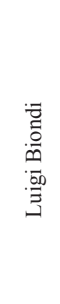 \\
\hline . & 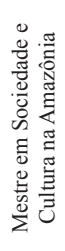 & 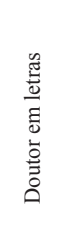 & 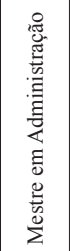 & 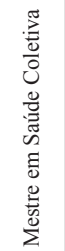 & 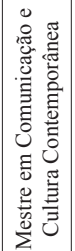 & 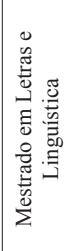 & 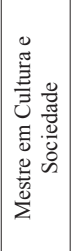 & 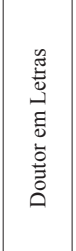 & 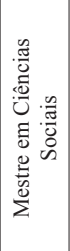 & 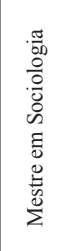 & 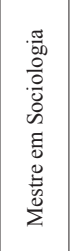 & 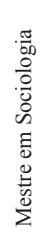 & 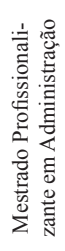 & 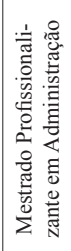 & 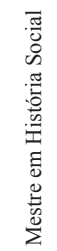 \\
\hline 总 & $\sum_{S}$ & $\begin{array}{l}\overleftrightarrow{\infty} \\
\text { 罗 }\end{array}$ & $\begin{array}{l}\overleftrightarrow{m} \\
\text { 䍐 }\end{array}$ & $\begin{array}{l}\overleftrightarrow{\infty} \\
\text { 号 }\end{array}$ & $\begin{array}{l}\overleftrightarrow{m} \\
\text { 罢 }\end{array}$ & $\begin{array}{l}\overleftrightarrow{m} \\
\text { 号 }\end{array}$ & $\begin{array}{l}\overleftrightarrow{m} \\
\stackrel{m}{S}\end{array}$ & $\begin{array}{l}\overleftrightarrow{\infty} \\
\text { 号 }\end{array}$ & $\begin{array}{l}\overleftrightarrow{\infty} \\
\text { 号 }\end{array}$ & U & 它 & U & U & 诘 & 号 \\
\hline 홀 & 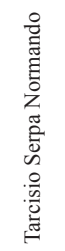 & 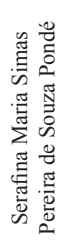 & 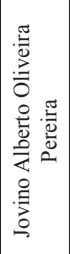 & 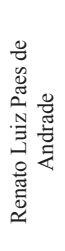 & 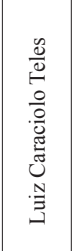 & 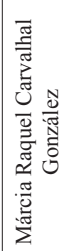 & 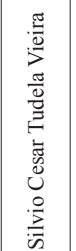 & 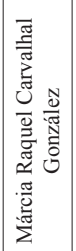 & 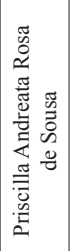 & 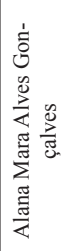 & 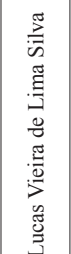 & 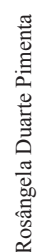 & 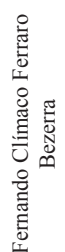 & 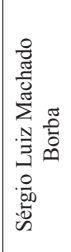 & 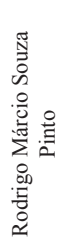 \\
\hline 을 & 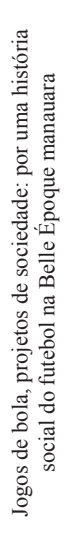 & 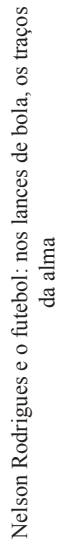 & 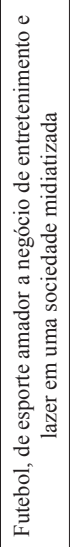 & 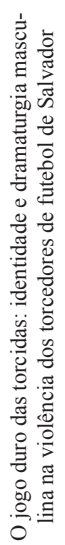 & 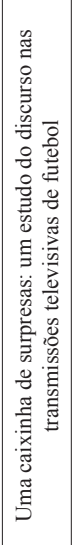 & 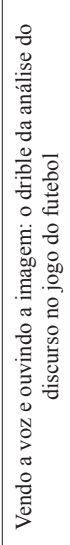 & 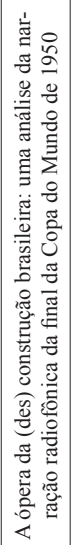 & 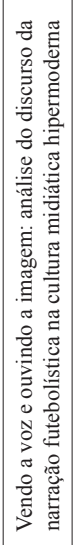 & 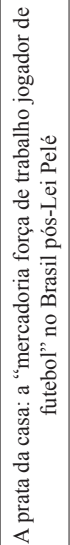 & 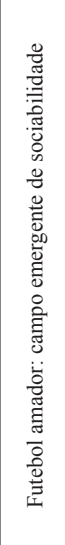 & 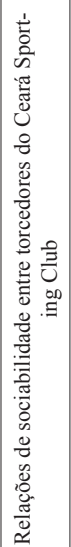 & 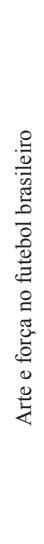 & 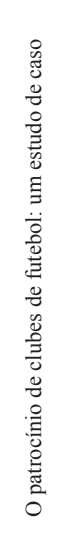 & 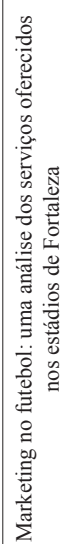 & 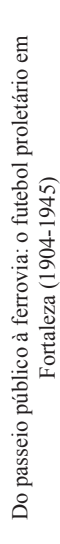 \\
\hline
\end{tabular}




\begin{tabular}{|c|c|c|c|c|c|c|c|c|c|c|c|c|c|c|c|}
\hline $\begin{array}{l}\text { 믐 } \\
\text { 몋ㅎ⿺ }\end{array}$ & ठ્ণે & $\stackrel{\circ}{2}$ & ¿্రి & ¿્రి & ¿্స & ¿ั่ & ః् & ¿े & \&్రి & $\stackrel{2}{\Omega}$ & $\stackrel{\alpha}{\sigma}$ & $\stackrel{2}{\circ}$ & 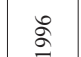 & 2 & gे \\
\hline 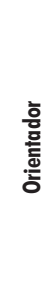 & 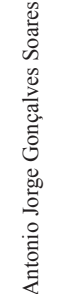 & 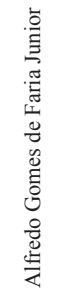 & 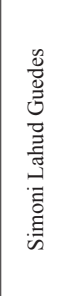 & 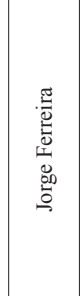 & 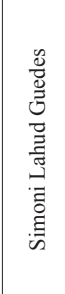 & 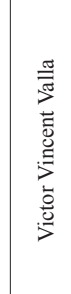 & 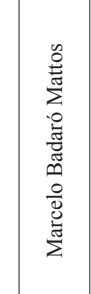 & 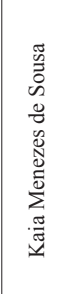 & 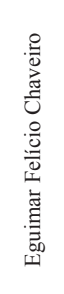 & 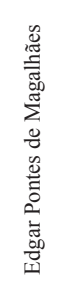 & 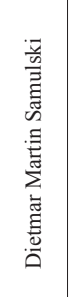 & 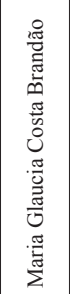 & 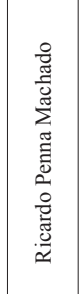 & 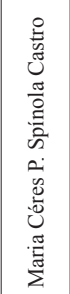 & 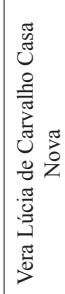 \\
\hline . & 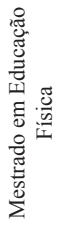 & 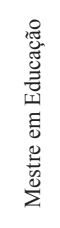 & 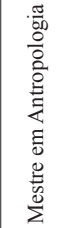 & 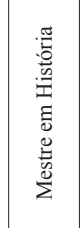 & 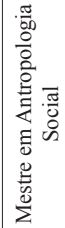 & 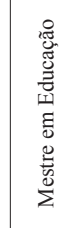 & 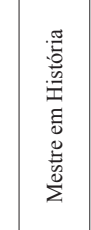 & 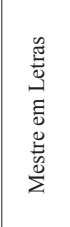 & 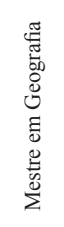 & 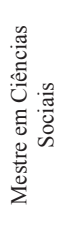 & 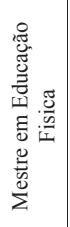 & 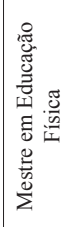 & 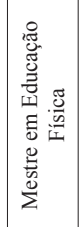 & 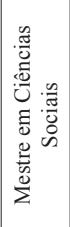 & 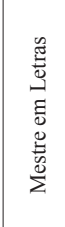 \\
\hline 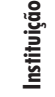 & $\begin{array}{l}\text { 岱 } \\
\text { 号 }\end{array}$ & 齿 & 崖 & 陆 & 㭊 & 崖 & 崖 & $\begin{array}{l}0 \\
\text { S }\end{array}$ & 诘 & $\sum_{\sum_{S}}^{U}$ & $\sum_{\sum_{S}}^{O}$ & $\sum_{S}^{O}$ & $\sum_{S}^{O}$ & $\sum_{S}^{O}$ & 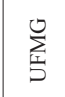 \\
\hline ㅎํㄹ & 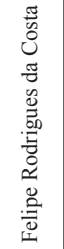 & 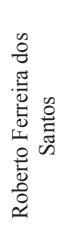 & 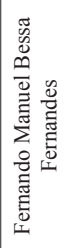 & 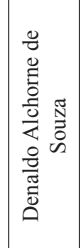 & 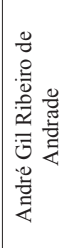 & 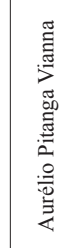 & 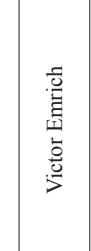 & 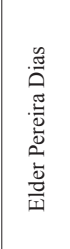 & 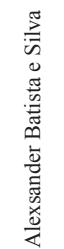 & 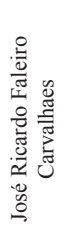 & 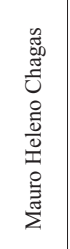 & 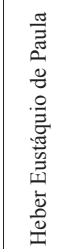 & 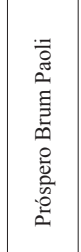 & 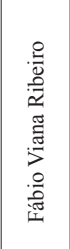 & 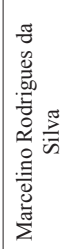 \\
\hline 을 & 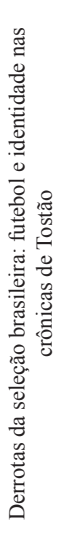 & 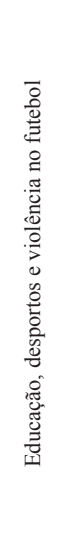 & 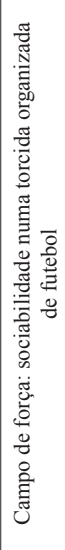 & 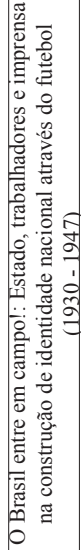 & 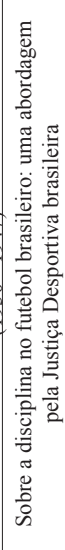 & 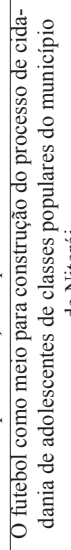 & 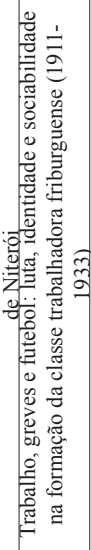 & 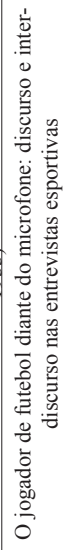 & 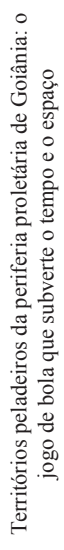 & 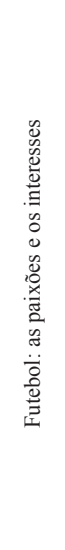 & 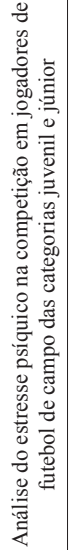 & 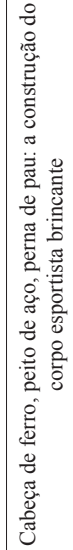 & 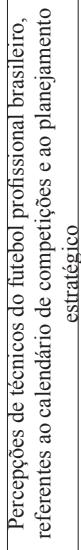 & 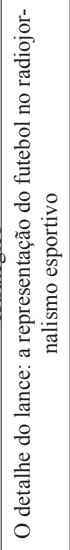 & 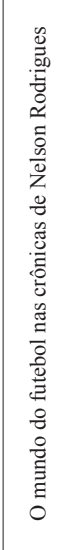 \\
\hline
\end{tabular}




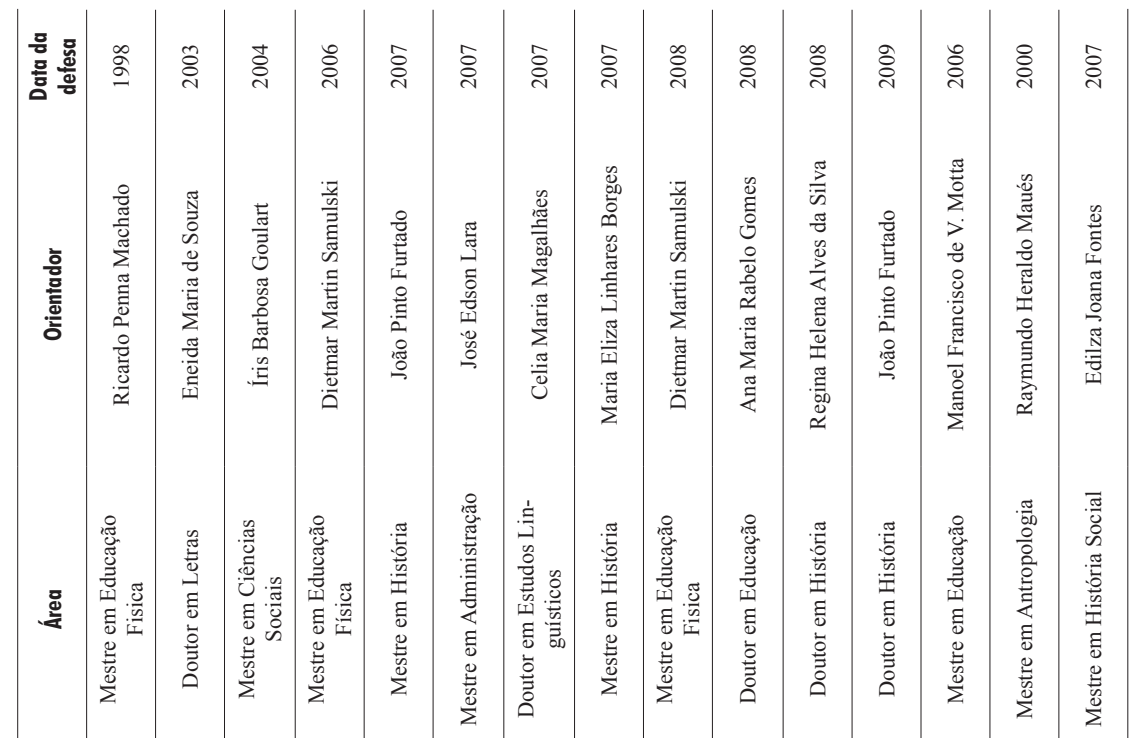

总

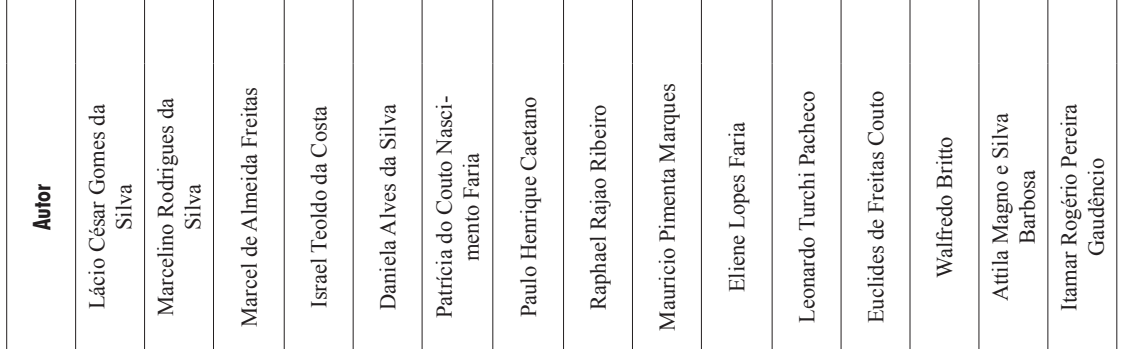

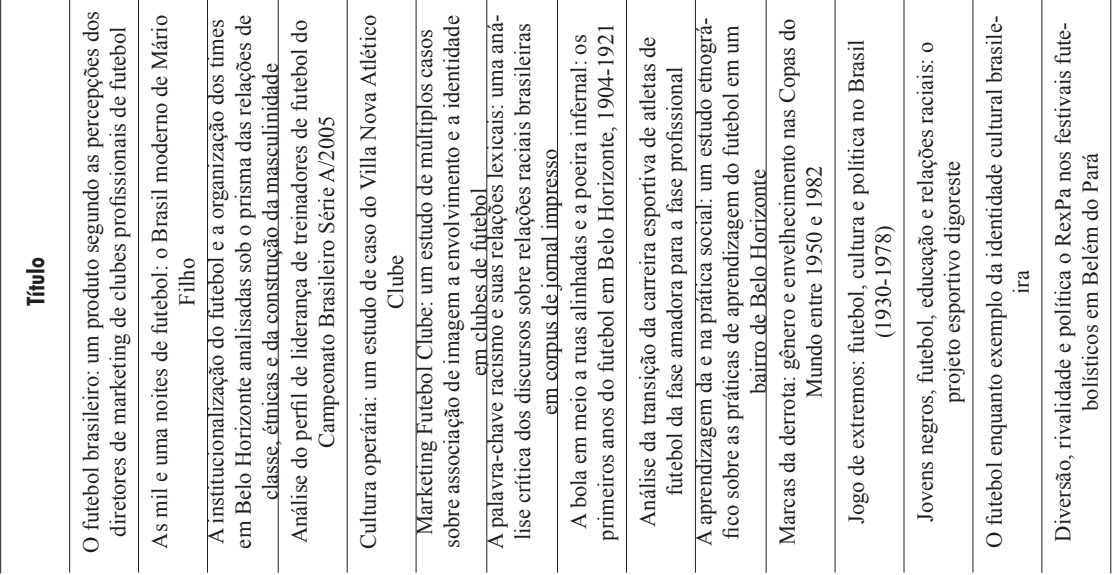




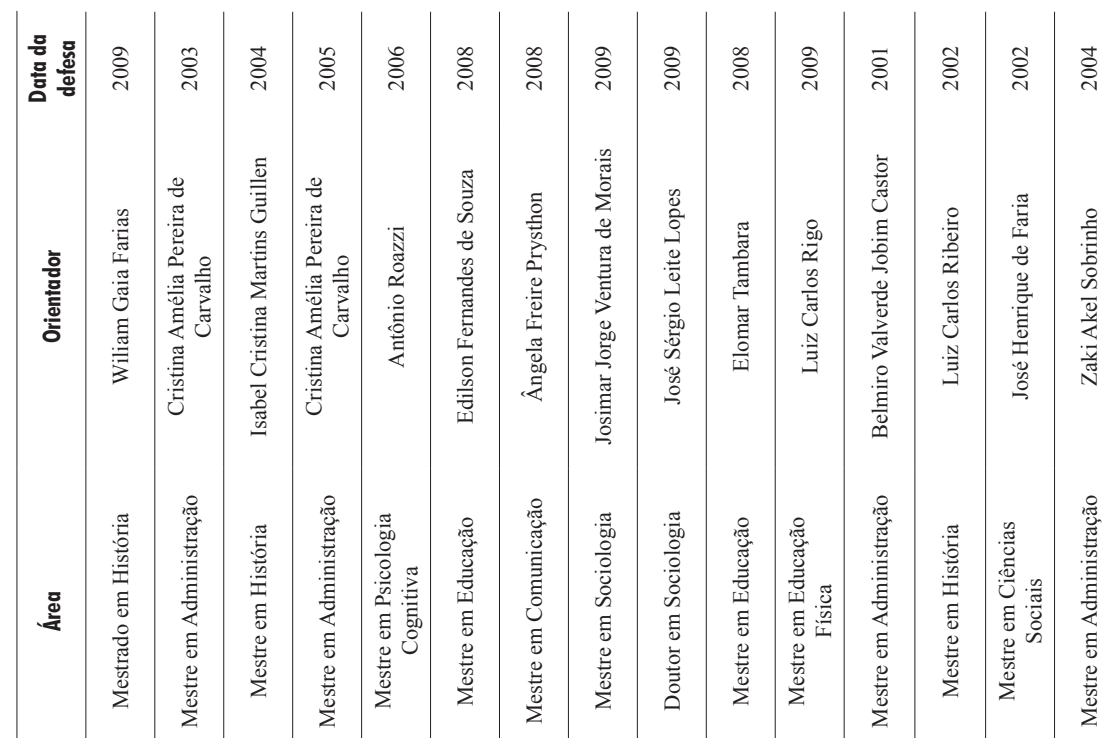

|

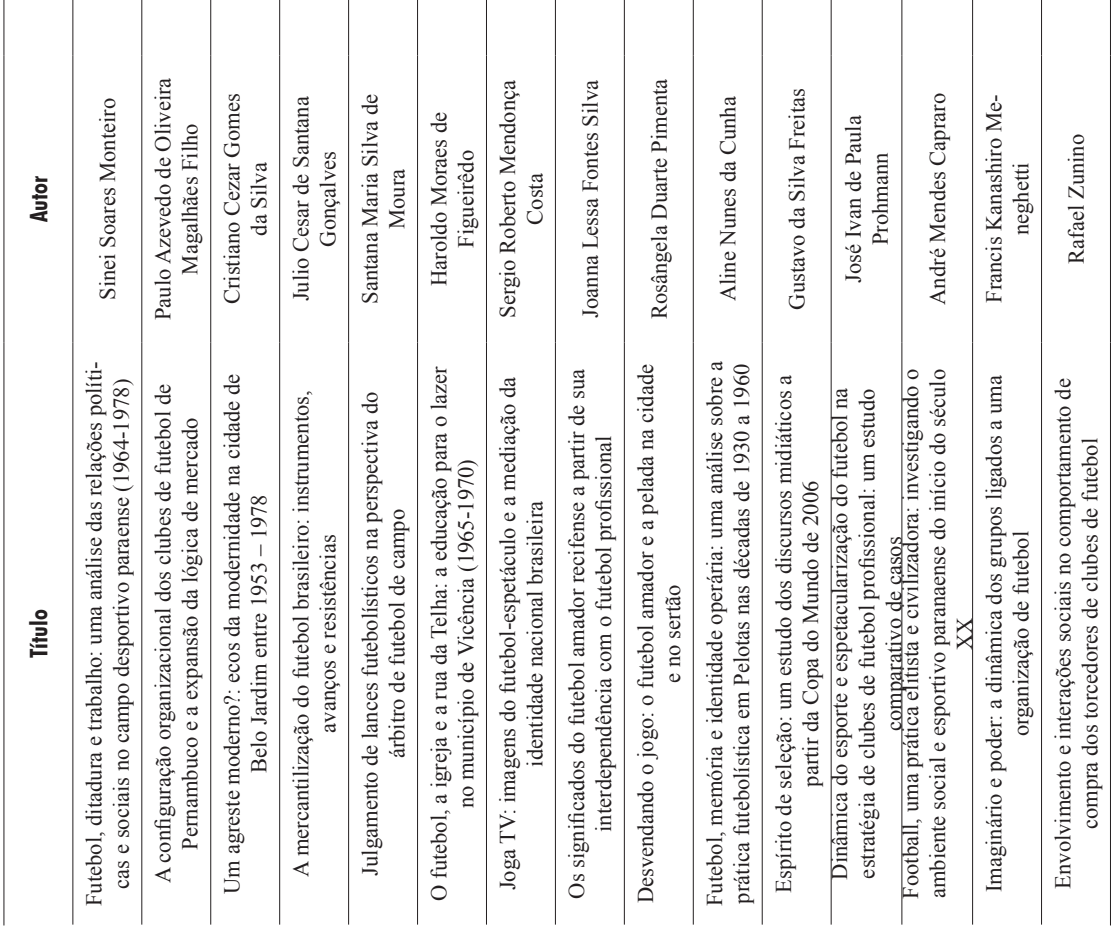




\begin{tabular}{|c|c|c|c|c|c|c|c|c|c|c|c|c|c|c|}
\hline 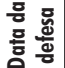 & 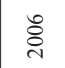 & 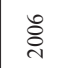 & 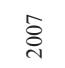 & ఃે & ¿્તે & ๕్ & 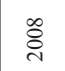 & ¿્సે & હ્તे & & 宂 & $\stackrel{\infty}{2}$ & $\sigma$ & ¿্ণ \\
\hline $\begin{array}{l}\text { 흠 } \\
\text { 흫 } \\
\text {. }\end{array}$ & 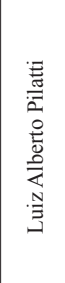 & 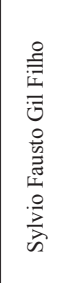 & 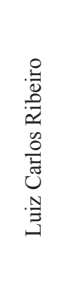 & 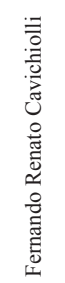 & 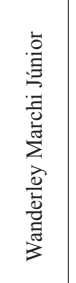 & 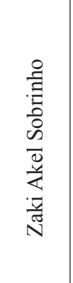 & 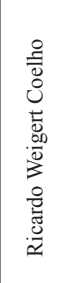 & 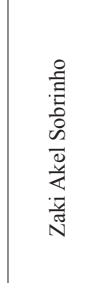 & 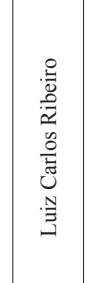 & 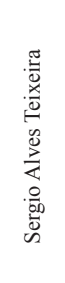 & 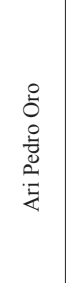 & 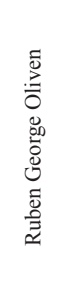 & 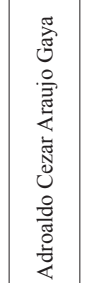 & 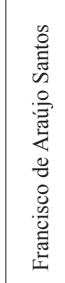 \\
\hline 尊 & 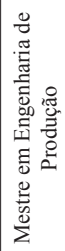 & 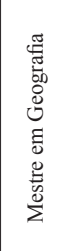 & 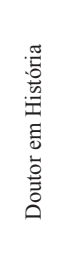 & 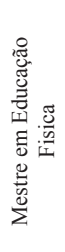 & 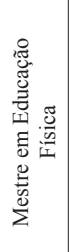 & 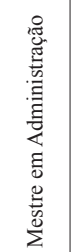 & 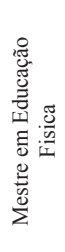 & 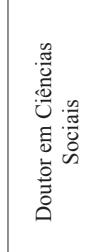 & 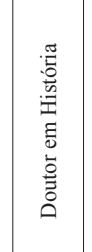 & 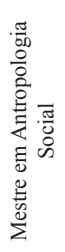 & 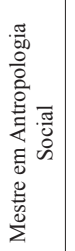 & 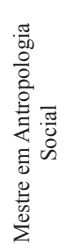 & 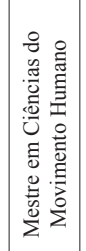 & 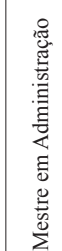 \\
\hline 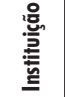 & 总 & 总 & 总 & 总 & 丠 & 营 & 总 & 总 & 䓂 & $\begin{array}{l}\text { U } \\
\frac{2}{5} \\
\frac{2}{S}\end{array}$ & $\begin{array}{l}\text { S } \\
\frac{2}{5} \\
\end{array}$ & 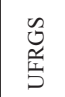 & $\begin{array}{l}\text { Uू } \\
\frac{\mathscr{N}}{S}\end{array}$ & $\begin{array}{l}\text { S } \\
\frac{\pi}{5} \\
\text { S }\end{array}$ \\
\hline 홀 & 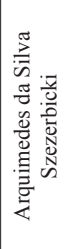 & 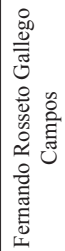 & 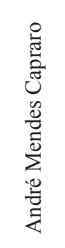 & 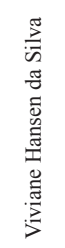 & 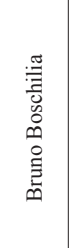 & 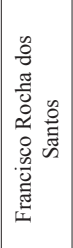 & 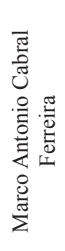 & 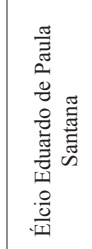 & 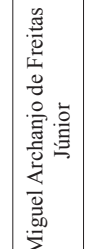 & 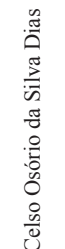 & 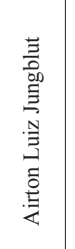 & 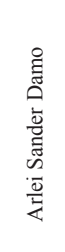 & 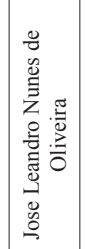 & 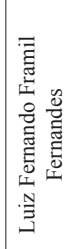 \\
\hline 논 & 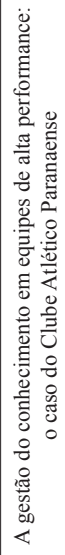 & 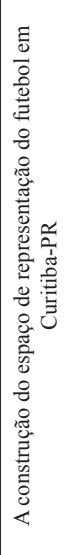 & 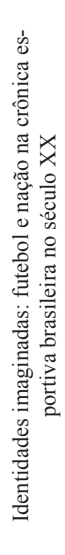 & 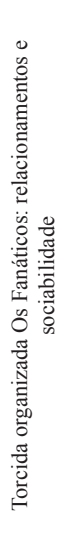 & 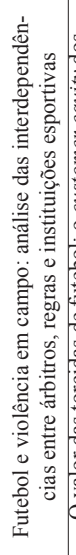 & 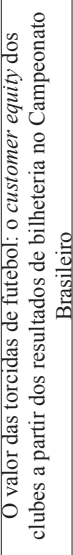 & 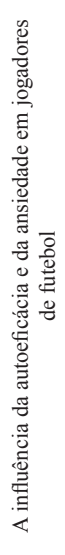 & 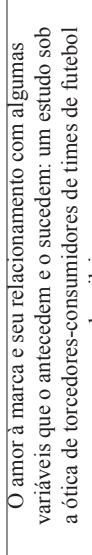 & 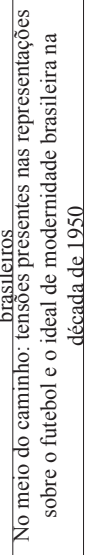 & 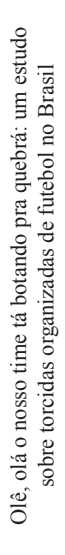 & 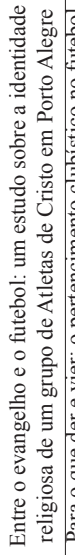 & 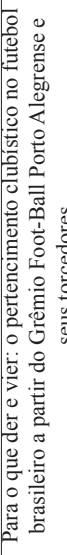 & 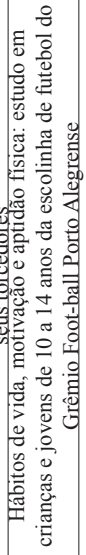 & 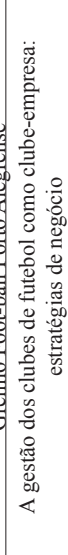 \\
\hline
\end{tabular}




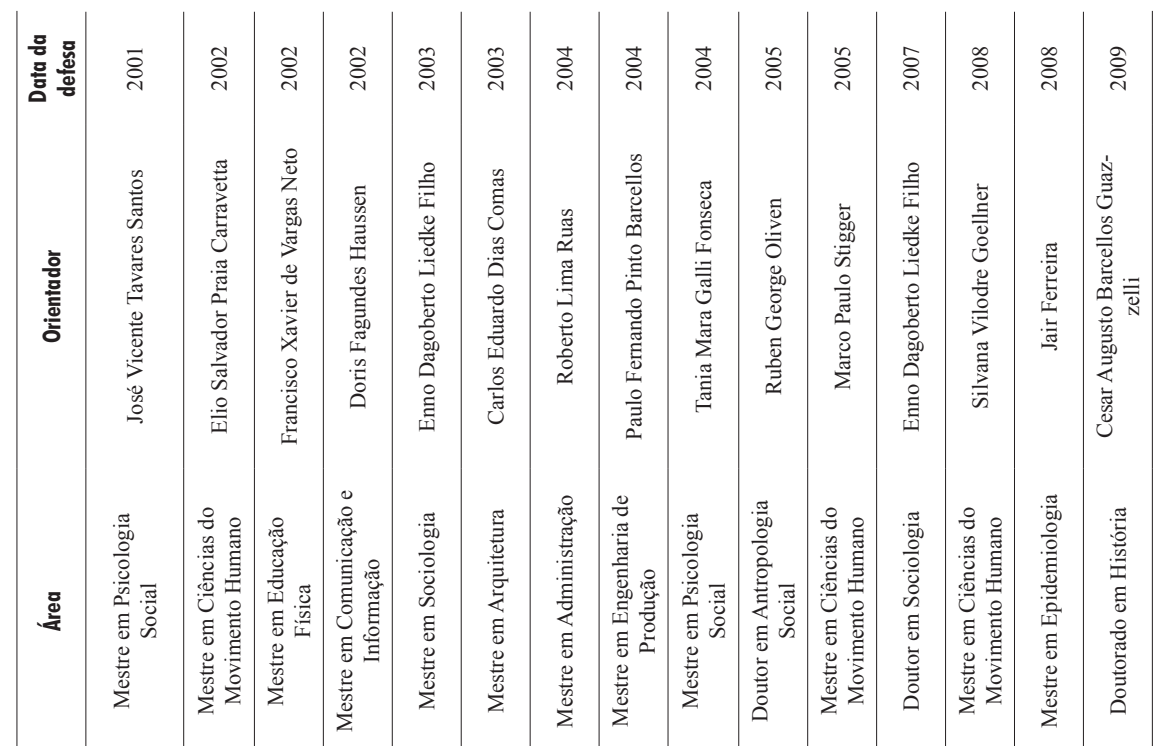

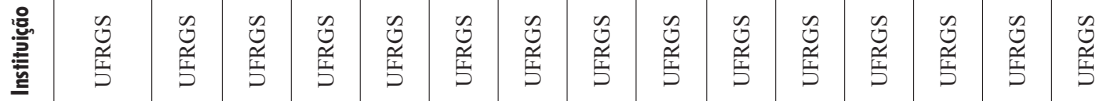

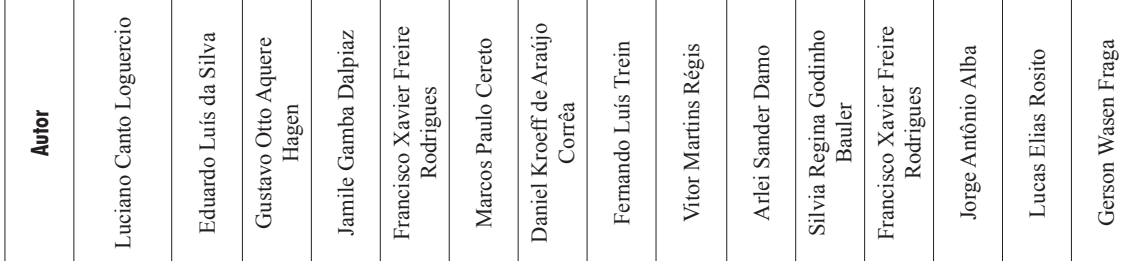

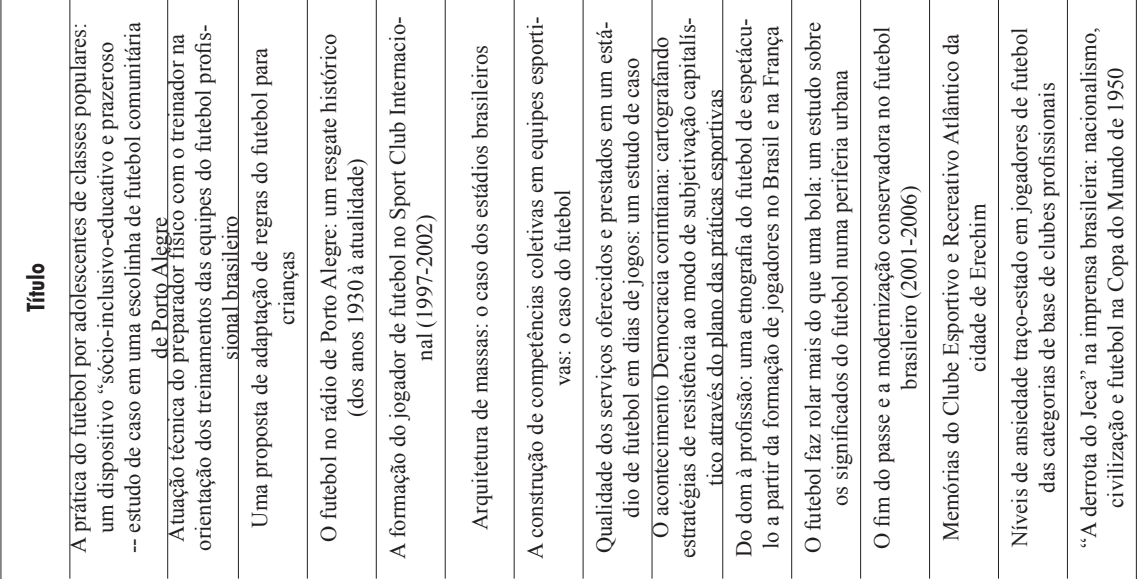




\begin{tabular}{|c|c|c|c|c|c|c|c|c|c|c|c|c|c|c|c|}
\hline 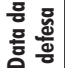 & ¿্ণ & 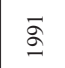 & ळ & ठे & 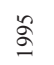 & $\stackrel{2}{\circ}$ & ळे & $\stackrel{\infty}{\sigma}$ & $\stackrel{\sigma}{\sigma}$ & बे & ळे & ¿્సે & 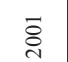 & ષ્సి & ¿্ণ \\
\hline 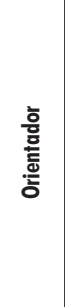 & 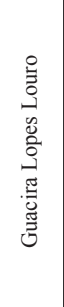 & 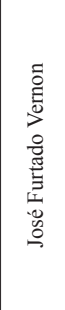 & 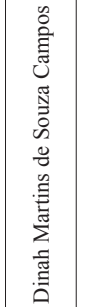 & 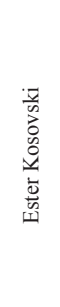 & 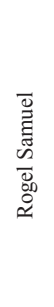 & 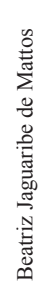 & 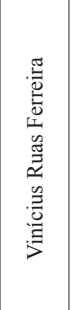 & 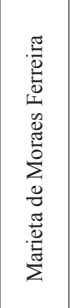 & 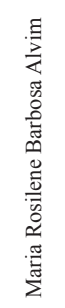 & 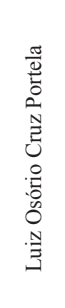 & 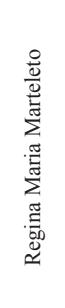 & 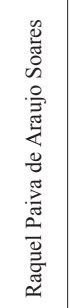 & 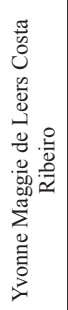 & 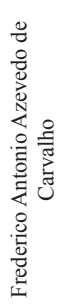 & 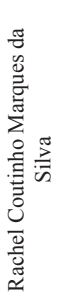 \\
\hline 奠 & 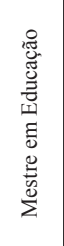 & 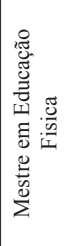 & 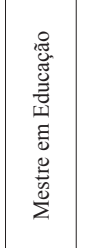 & 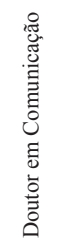 & 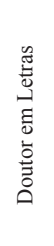 & 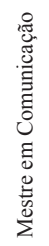 & 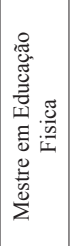 & 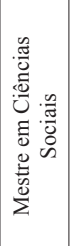 & 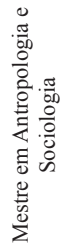 & 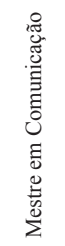 & 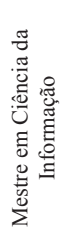 & 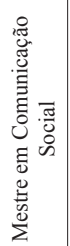 & 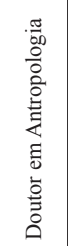 & 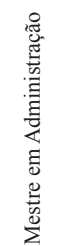 & 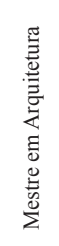 \\
\hline 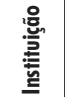 & 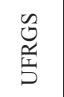 & $\frac{\overrightarrow{2}}{\vec{S}}$ & $\frac{\overrightarrow{2}}{5}$ & 战 & $\begin{array}{l}\overrightarrow{\mathrm{q}} \\
\mathrm{S}\end{array}$ & $\begin{array}{l}\overrightarrow{2} \\
\text { S }\end{array}$ & $\begin{array}{l}\overrightarrow{\widetilde{z}} \\
\overrightarrow{5}\end{array}$ & $\begin{array}{l}\overrightarrow{\widetilde{z}} \\
\overrightarrow{5}\end{array}$ & $\overrightarrow{\widetilde{Z}}$ & $\frac{\vec{\alpha}}{5}$ & $\begin{array}{l}\overrightarrow{2} \\
\overrightarrow{5}\end{array}$ & 疍 & $\begin{array}{l}\vec{z} \\
\overrightarrow{5}\end{array}$ & $\frac{\vec{\alpha}}{5}$ & $\begin{array}{l}\overrightarrow{2} \\
\frac{\vec{z}}{5}\end{array}$ \\
\hline 훌 & 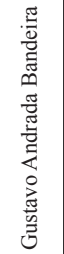 & 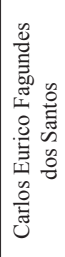 & 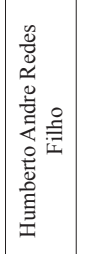 & 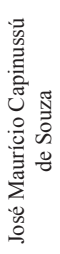 & 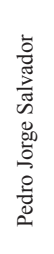 & 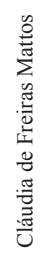 & 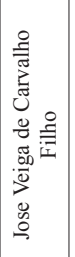 & 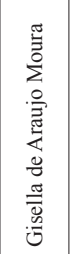 & 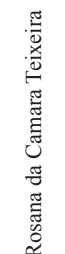 & 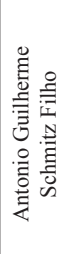 & 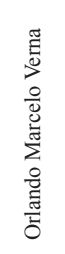 & 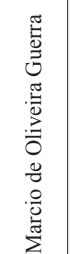 & 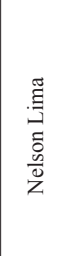 & 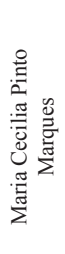 & 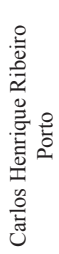 \\
\hline 을 & 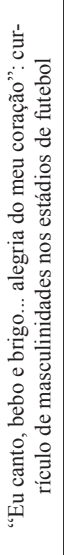 & 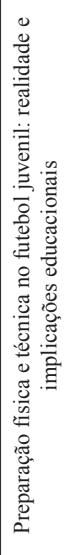 & 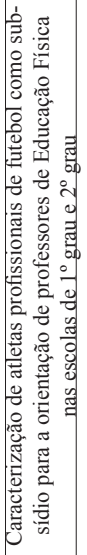 & 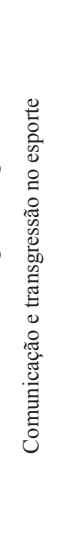 & 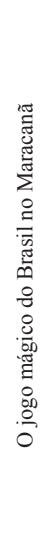 & 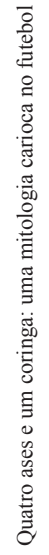 & 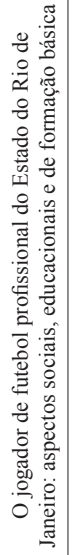 & 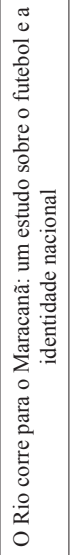 & 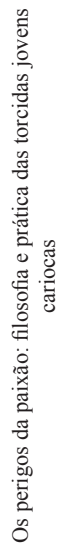 & 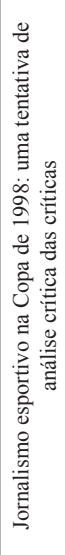 & 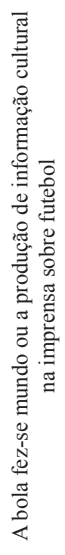 & 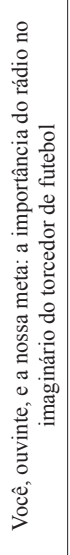 & 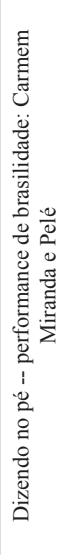 & 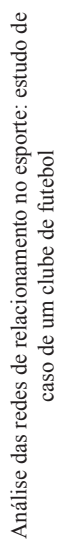 & 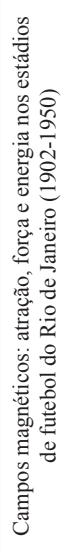 \\
\hline
\end{tabular}




\begin{tabular}{|c|c|c|c|c|c|c|c|c|c|c|c|c|c|c|c|}
\hline $\begin{array}{l}\text { 믐 } \\
\text { 믛 }\end{array}$ & ఫ్రి & 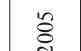 & 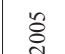 & $\stackrel{\circ}{0}$ & $\stackrel{ه}{\circ}$ & $\stackrel{ه}{\circ}$ & ఠั้ & 。ั & \& & $\stackrel{0}{0}$ & ठे & ฉ & à & $\stackrel{\infty}{\circ}$ & ¿ \\
\hline $\begin{array}{l}\frac{\text { 흘 }}{\bar{t}} \\
\text { 흫 }\end{array}$ & 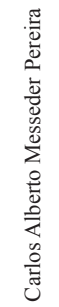 & 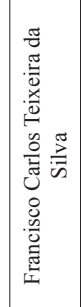 & $\begin{array}{l}0 \\
0 \\
0 \\
0 \\
0 \\
0 \\
0 \\
0 \\
0 \\
0 \\
0 \\
0 \\
0 \\
0 \\
0 \\
0 \\
0\end{array}$ & 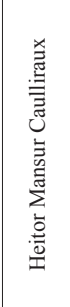 & 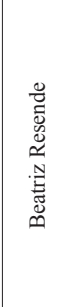 & 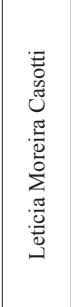 & 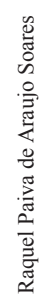 & 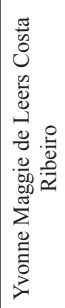 & 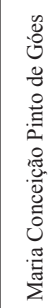 & 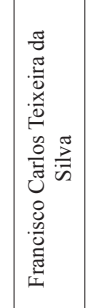 & 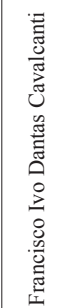 & 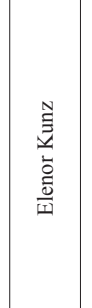 & 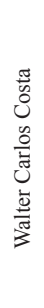 & 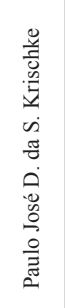 & 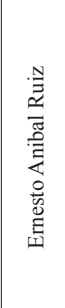 \\
\hline 尊 & 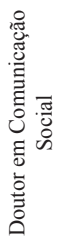 & 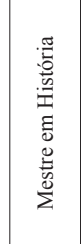 & 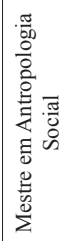 & 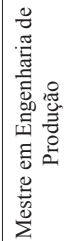 & 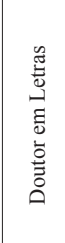 & 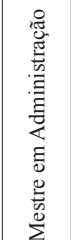 & 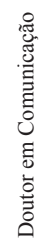 & 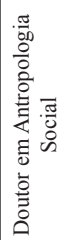 & 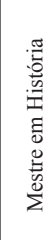 & 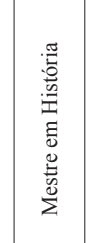 & 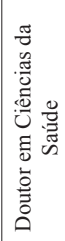 & 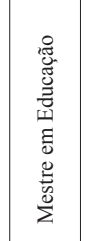 & 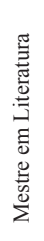 & 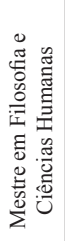 & 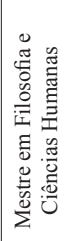 \\
\hline 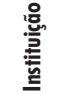 & $\frac{\overrightarrow{2}}{S}$ & $\frac{\overrightarrow{2}}{S}$ & 茎 & $\begin{array}{l}\overrightarrow{2} \\
\text { 至 }\end{array}$ & $\begin{array}{l}\overrightarrow{\widetilde{\gamma}} \\
\overrightarrow{5}\end{array}$ & $\begin{array}{l}\overrightarrow{2} \\
\frac{\vec{F}}{5}\end{array}$ & $\frac{\overrightarrow{2}}{5}$ & $\begin{array}{l}\overrightarrow{2} \\
\frac{\overrightarrow{2}}{5}\end{array}$ & $\begin{array}{l}\overrightarrow{2} \\
\text { 空 }\end{array}$ & $\begin{array}{l}\overrightarrow{2} \\
\frac{\vec{S}}{5}\end{array}$ & 旁 & $\begin{array}{l}\text { U } \\
\text { 敁 }\end{array}$ & $\begin{array}{l}\text { D } \\
\text { 号 } \\
\end{array}$ & $\begin{array}{l}\text { D } \\
\text { S' }\end{array}$ & $\begin{array}{l}\text { D } \\
\text { 罗 }\end{array}$ \\
\hline 혼 & 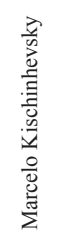 & 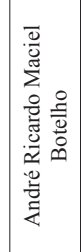 & 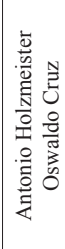 & $\begin{array}{l}\text { 志 } \\
\text { ○ } \\
\text { 言 } \\
\end{array}$ & 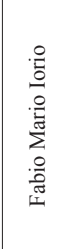 & 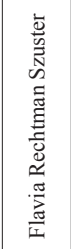 & 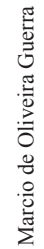 & 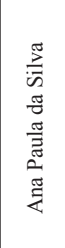 & 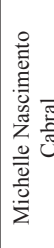 & 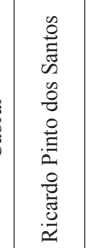 & 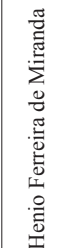 & 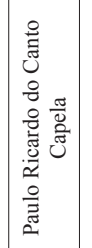 & 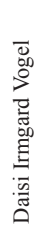 & 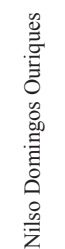 & 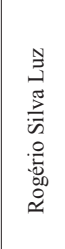 \\
\hline 을 & 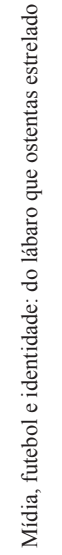 & 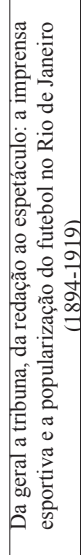 & 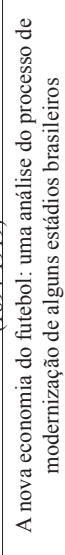 & 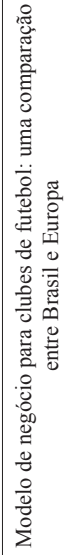 & 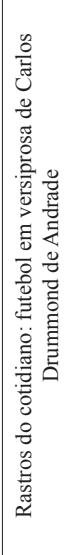 & 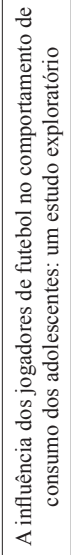 & 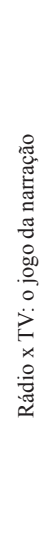 & 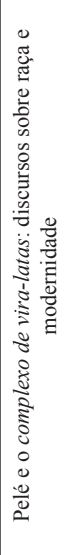 & 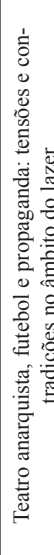 & 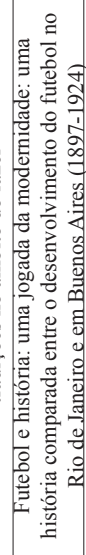 & 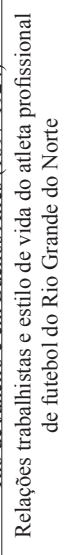 & 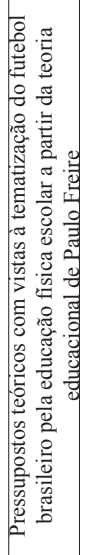 & 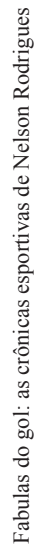 & 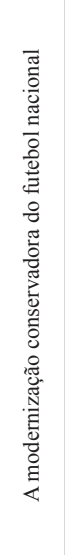 & 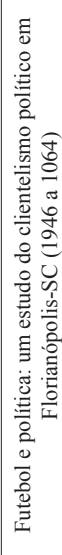 \\
\hline
\end{tabular}




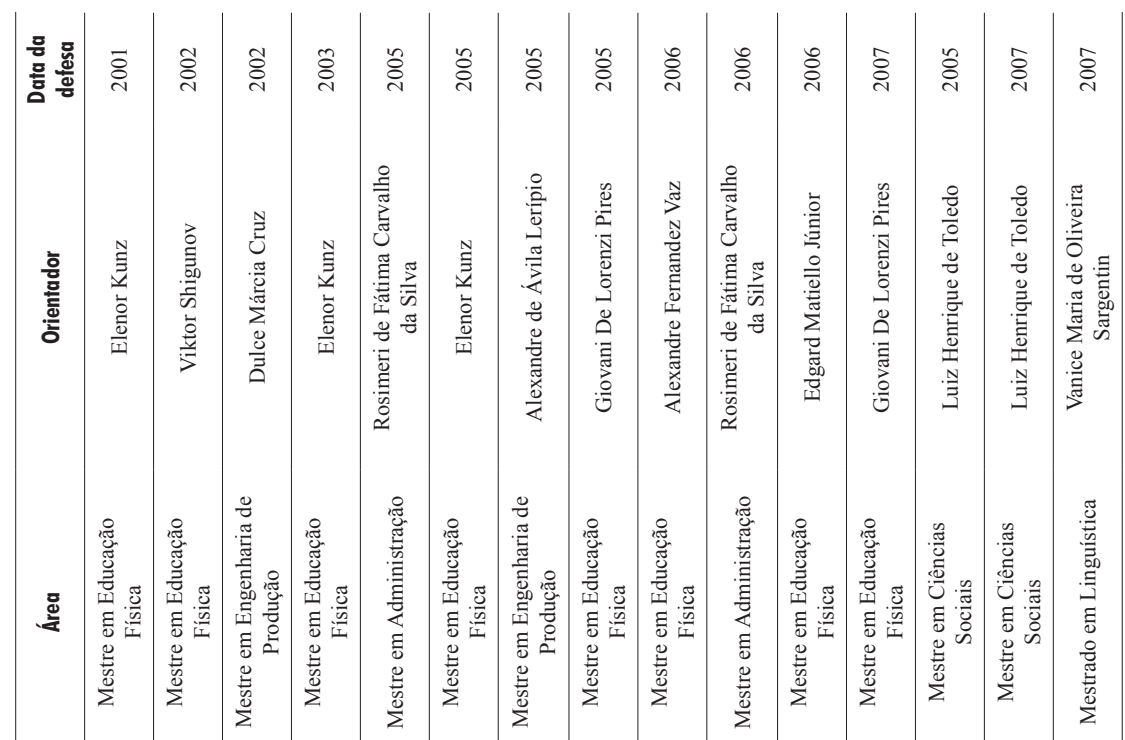

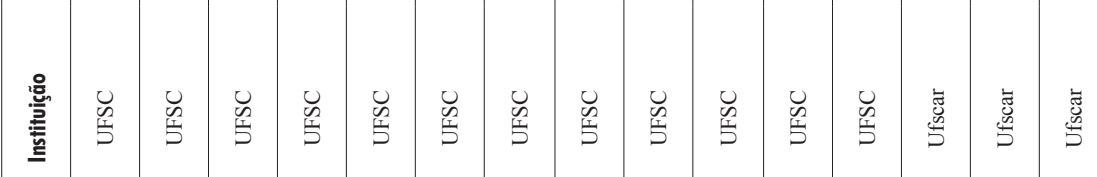

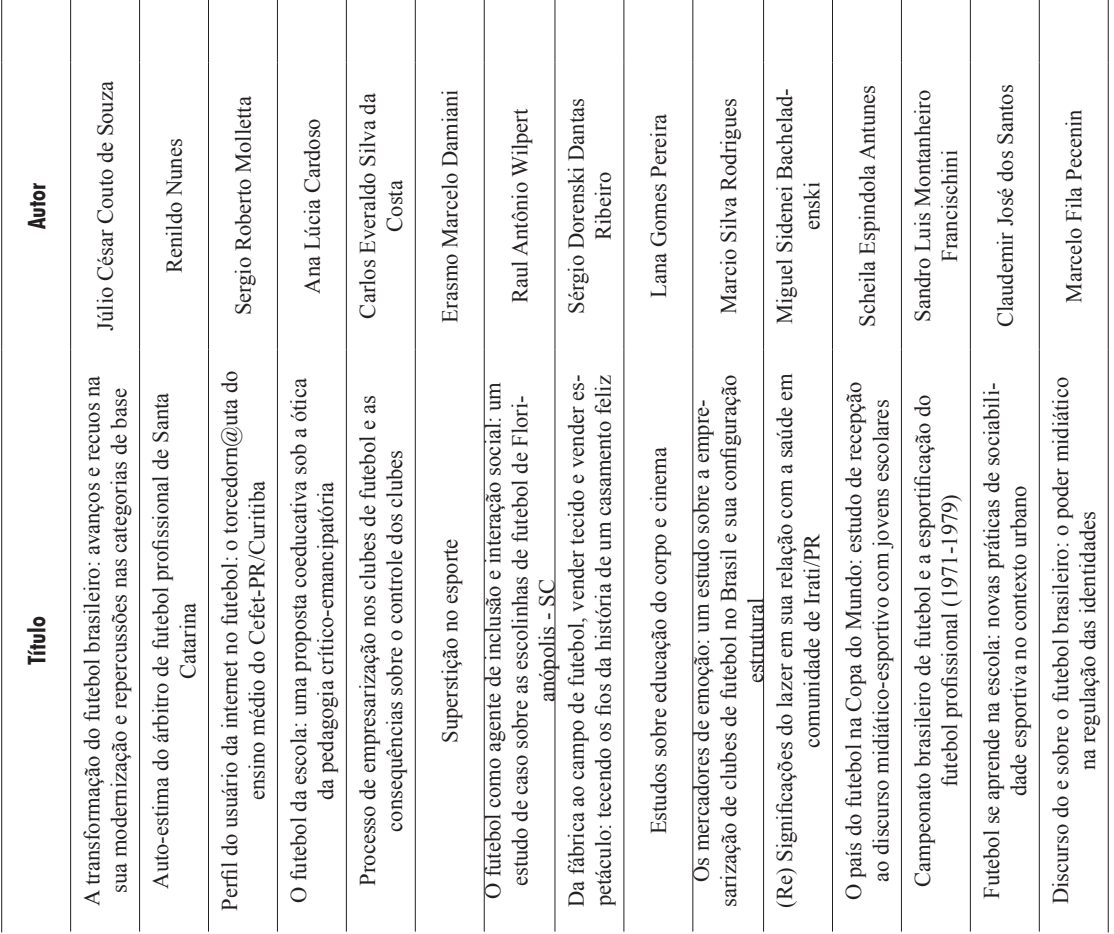




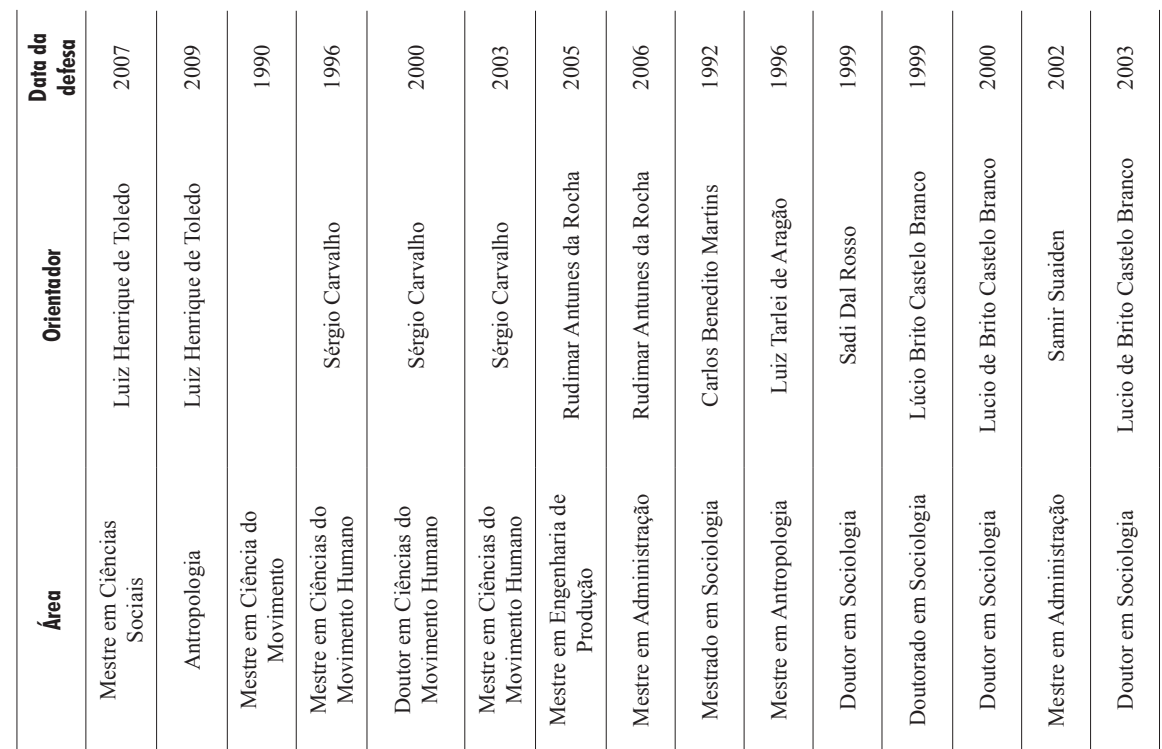

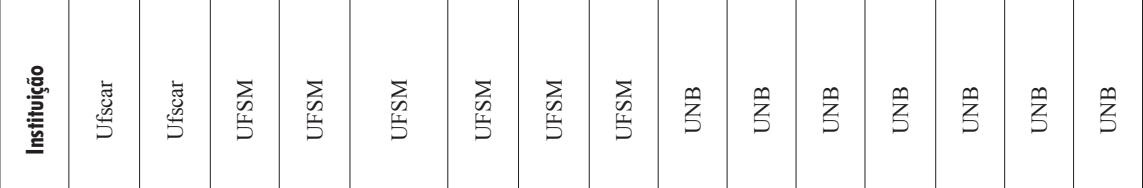

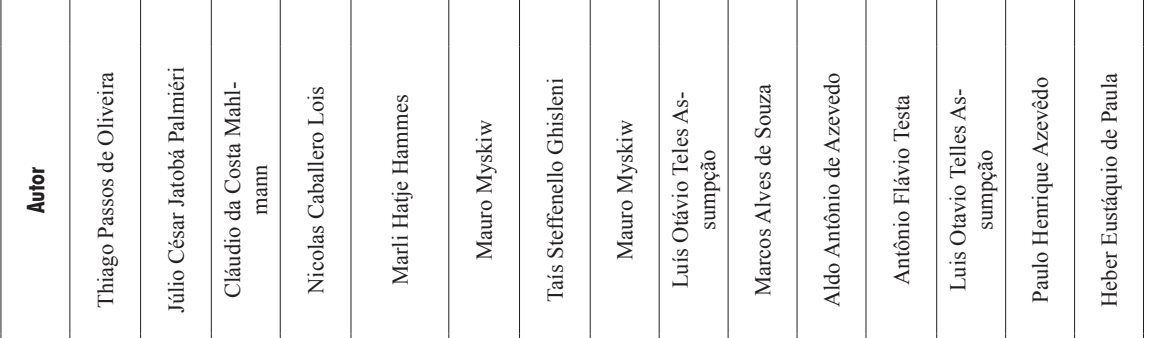

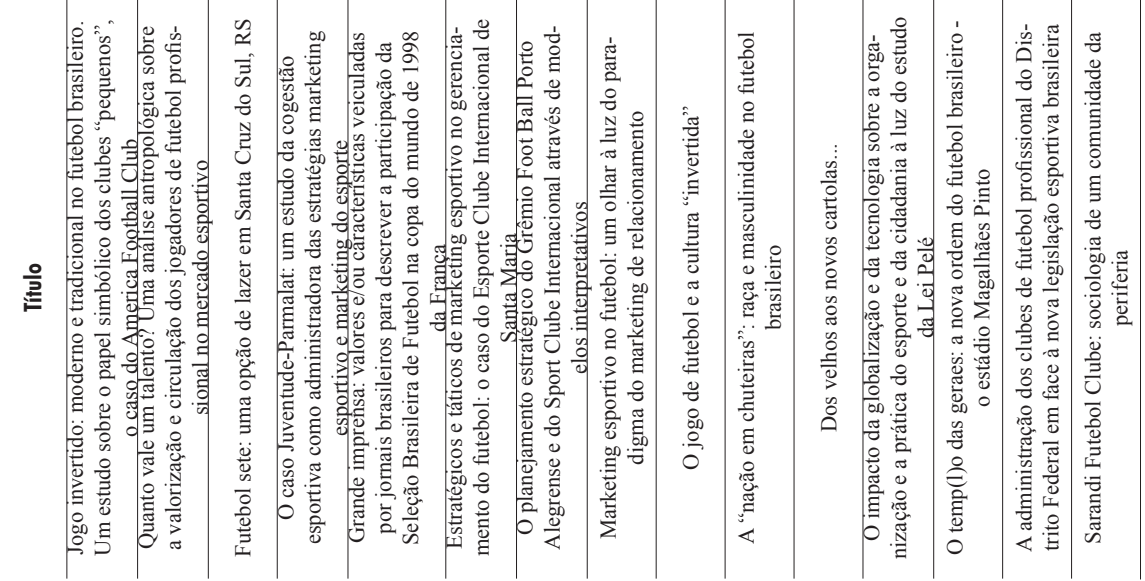




\begin{tabular}{|c|c|c|c|c|c|c|c|c|c|c|c|c|c|c|}
\hline 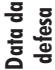 & ֻั & 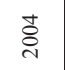 & ఫั & ڤัे & ¿্ণ & ષั้ & ષે & $\stackrel{\text { ¿े }}{\infty}$ & ¿্ণ & ڤे & ఫે & ๕ి & ๕ి & ¿્તે \\
\hline 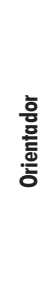 & 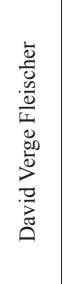 & 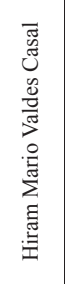 & 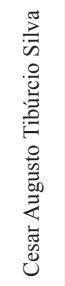 & 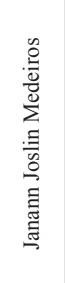 & 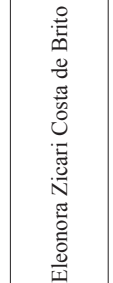 & 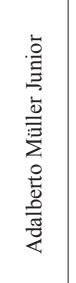 & 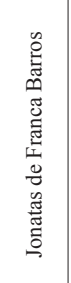 & 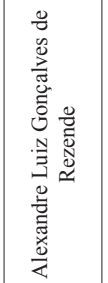 & 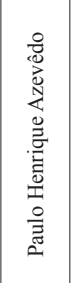 & 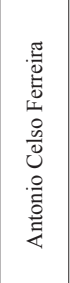 & 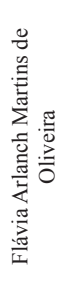 & 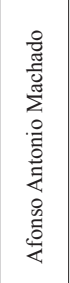 & 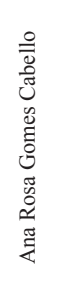 & 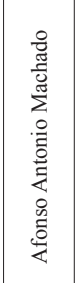 \\
\hline . & 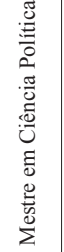 & 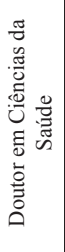 & 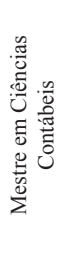 & 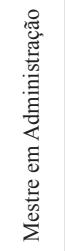 & 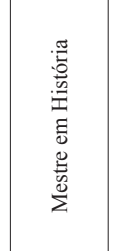 & 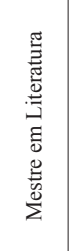 & 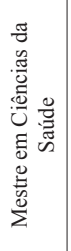 & 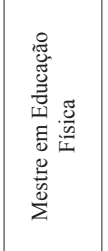 & 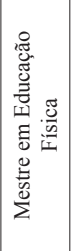 & 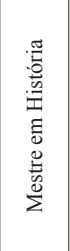 & 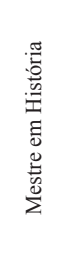 & 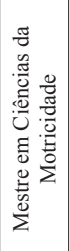 & 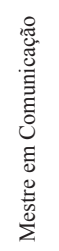 & 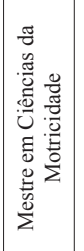 \\
\hline 总 & 㤐 & $\frac{n}{s}$ & 竞 & 帘 & 点 & $\frac{n}{5}$ & $\frac{n}{5}$ & 点 & $\frac{n}{s}$ & 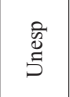 & $\begin{array}{l}\text { क्षे } \\
\text { ज्ञ }\end{array}$ & $\begin{array}{l}\stackrel{5}{8} \\
.5 \\
5\end{array}$ & $\begin{array}{l}\text { के } \\
\text { है }\end{array}$ & $\begin{array}{l}\text { के } \\
\text { क् }\end{array}$ \\
\hline 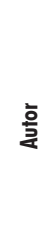 & 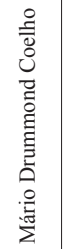 & 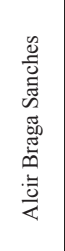 & 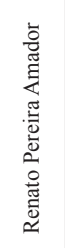 & 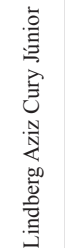 & 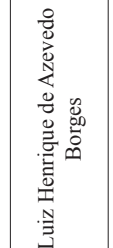 & 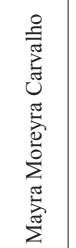 & 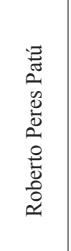 & 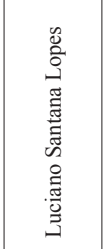 & 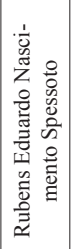 & 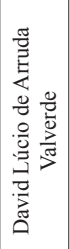 & 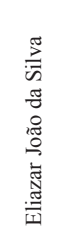 & 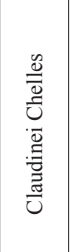 & 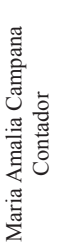 & 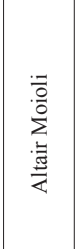 \\
\hline 을 & 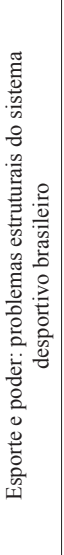 & 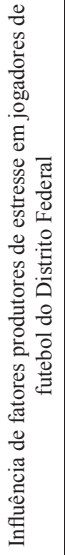 & 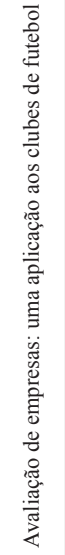 & 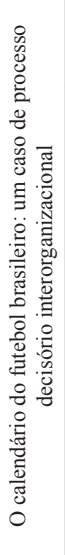 & 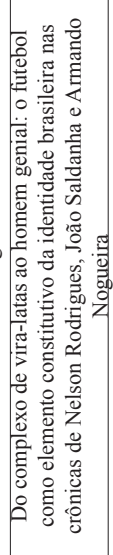 & 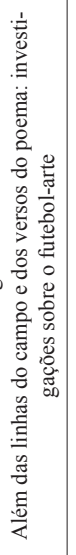 & 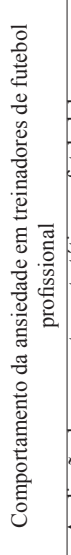 & 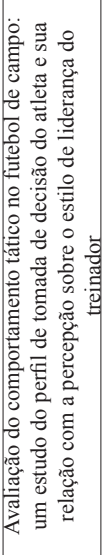 & 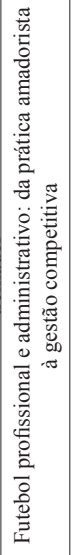 & 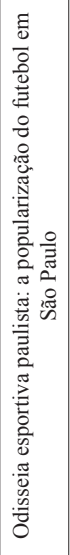 & 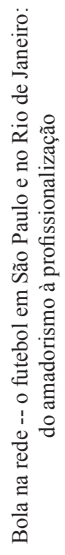 & 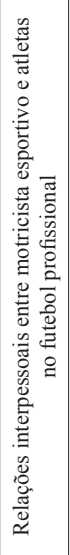 & 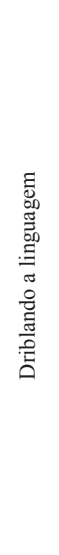 & 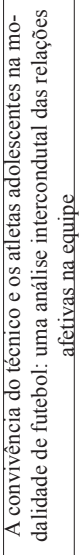 \\
\hline
\end{tabular}




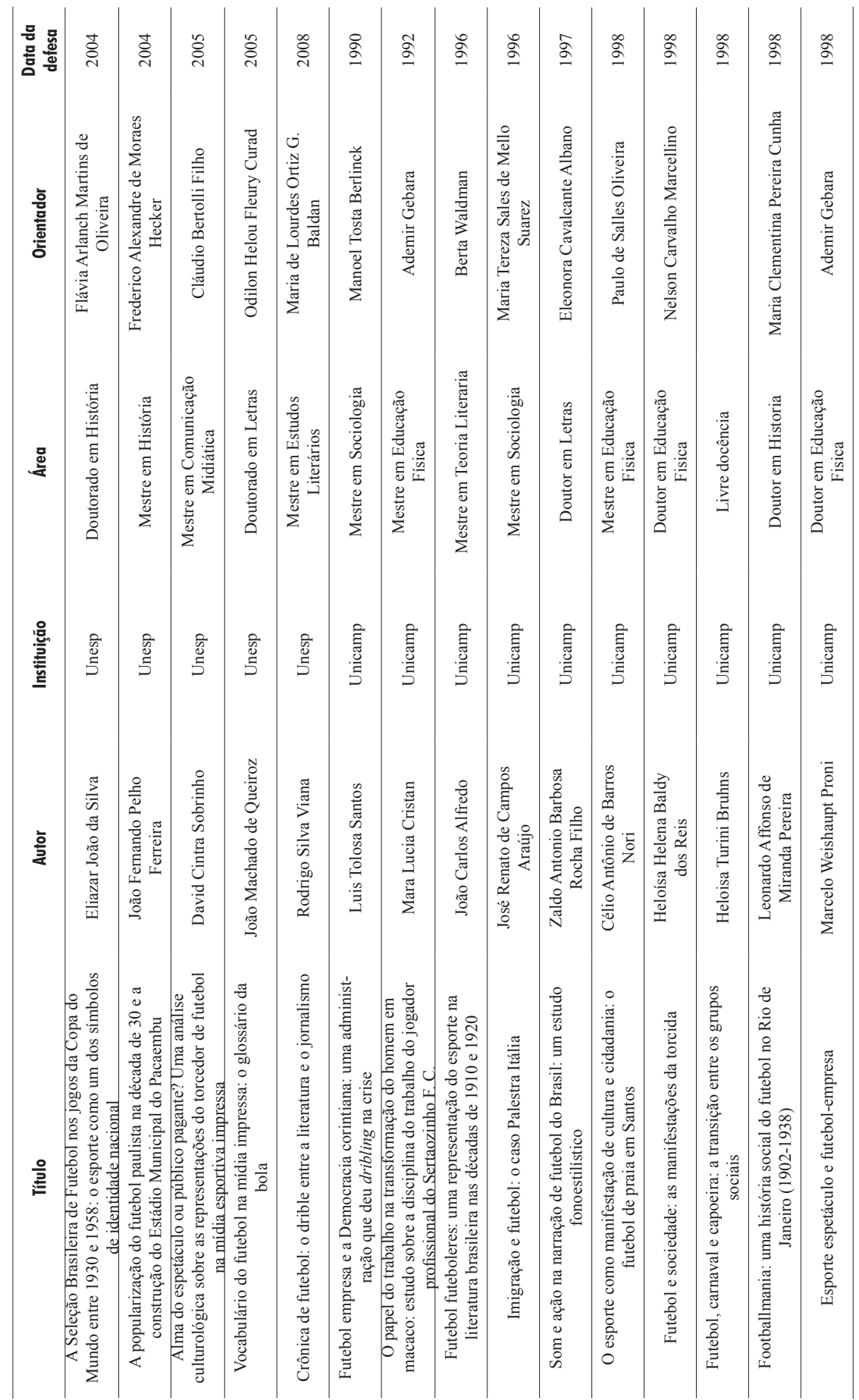




\begin{tabular}{|c|c|c|c|c|c|c|c|c|c|c|c|c|c|c|c|}
\hline 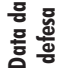 & ڤे & ळे & ¿્ర & ¿્ర & $\overline{\mathrm{N}}$ & $\overline{\mathrm{N}}$ & గ్రి & ڤ్ & ڤ్రి & ڤ్రి & ه్ & ষ্ণ & ڤ్ & ๕̊ & ¿્તે \\
\hline 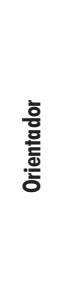 & 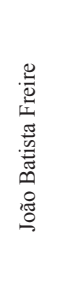 & 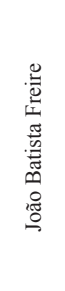 & 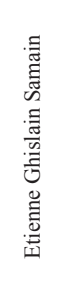 & 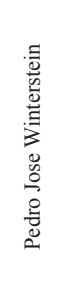 & 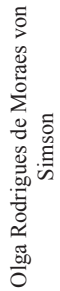 & 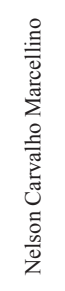 & 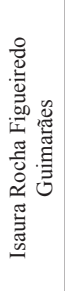 & 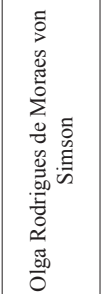 & 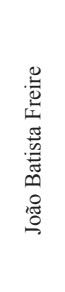 & 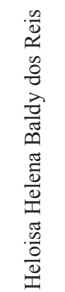 & 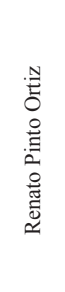 & & 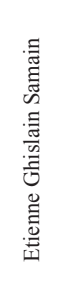 & 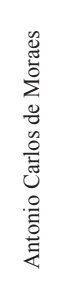 & 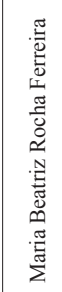 \\
\hline . & 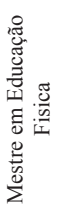 & 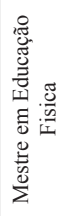 & 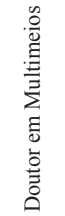 & 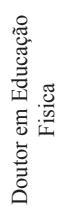 & 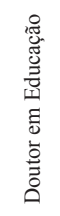 & 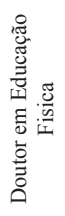 & 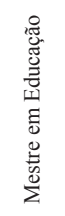 & 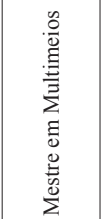 & 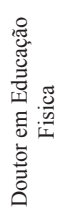 & 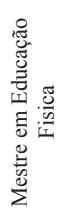 & 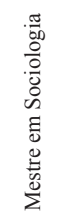 & 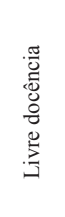 & 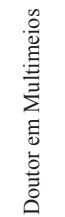 & 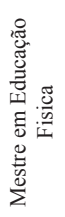 & 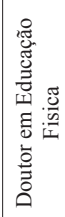 \\
\hline 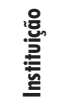 & 莺 & 莺 & 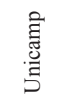 & 莺 & 密 & 莺 & 节 & 苞 & 营 & 萢 & 壹 & 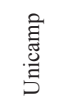 & 壹 & 䓛 & 駦 \\
\hline$\frac{\bar{o}}{\frac{3}{2}}$ & 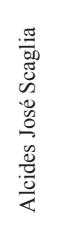 & 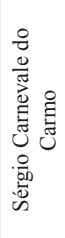 & 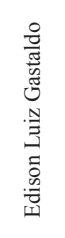 & 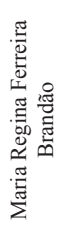 & 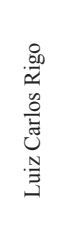 & 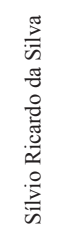 & 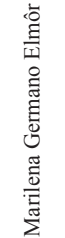 & 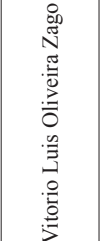 & 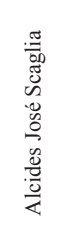 & 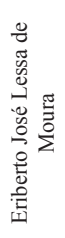 & 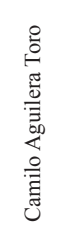 & 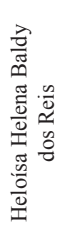 & 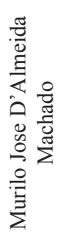 & 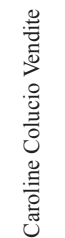 & 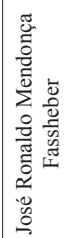 \\
\hline 을 & 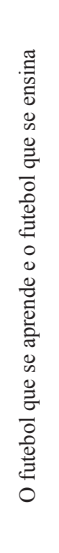 & 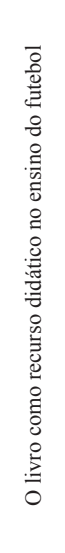 & 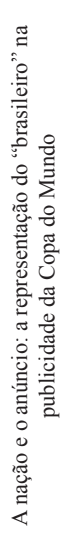 & 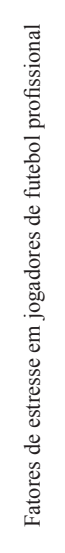 & 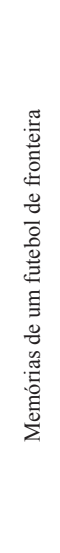 & 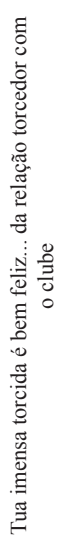 & 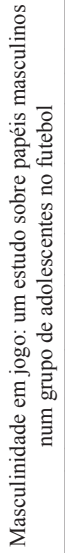 & 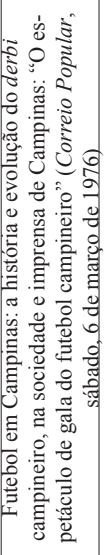 & 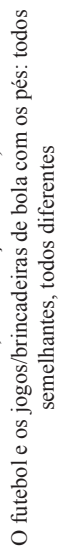 & 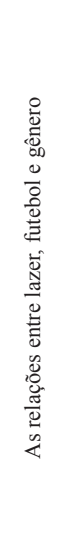 & 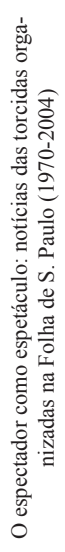 & 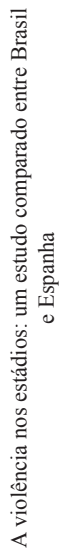 & 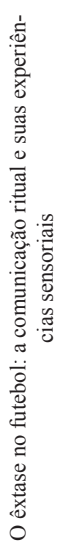 & 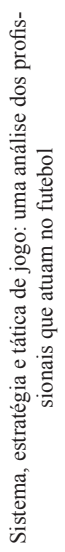 & 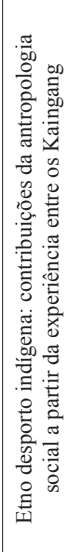 \\
\hline
\end{tabular}




\begin{tabular}{|c|c|c|c|c|c|c|c|c|c|c|c|c|c|c|c|}
\hline 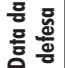 & 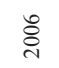 & 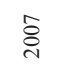 & ¿্ণి & ¿્స & \&్సి & $\stackrel{\text { ¿े }}{\infty}$ & ¿ें & ڤ્ণે & ه్ & ठ্ণ & ఫ్రి & $\stackrel{\text { ¿े }}{\infty}$ & ఏ્సે & ષ્તે & $\stackrel{\text { ¿े }}{\circ}$ \\
\hline $\begin{array}{l}\frac{\text { 흠 }}{\bar{t}} \\
\text { 흫 }\end{array}$ & 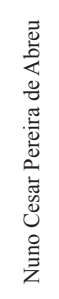 & 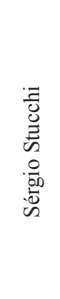 & 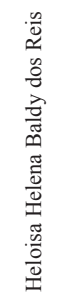 & 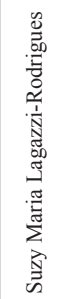 & 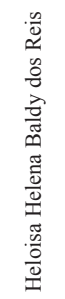 & 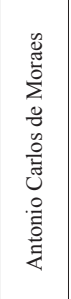 & 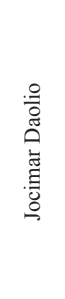 & 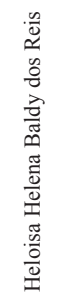 & 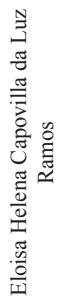 & 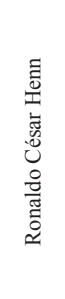 & 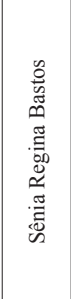 & 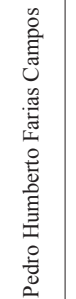 & 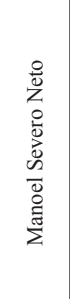 & 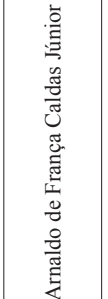 & 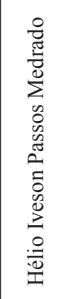 \\
\hline 党 & 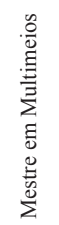 & 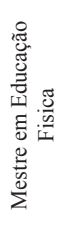 & 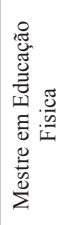 & 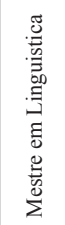 & 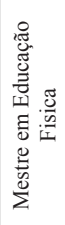 & 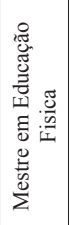 & 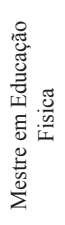 & 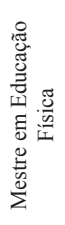 & 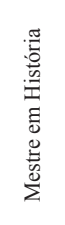 & 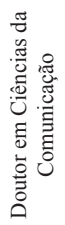 & 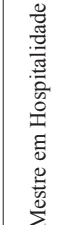 & 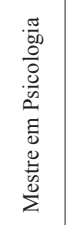 & 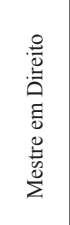 & 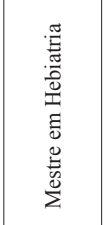 & 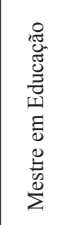 \\
\hline 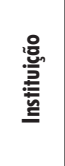 & 莺 & 害 & 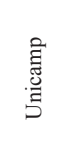 & 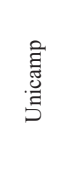 & 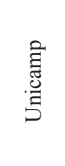 & 譱 & 䓌 & 萢 & 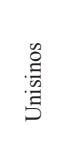 & 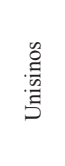 & 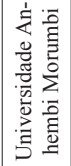 & 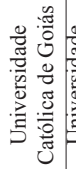 & 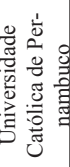 & 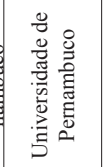 & 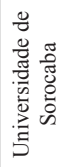 \\
\hline 홀 & 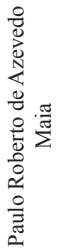 & 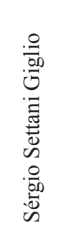 & 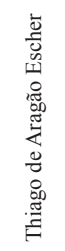 & 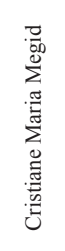 & 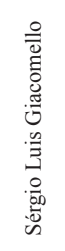 & 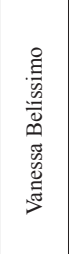 & 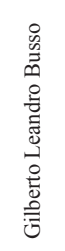 & 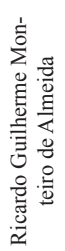 & 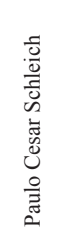 & 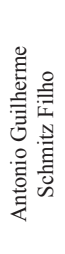 & 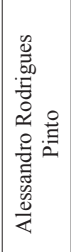 & 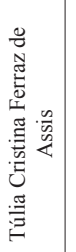 & 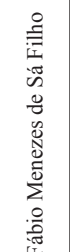 & 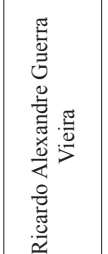 & 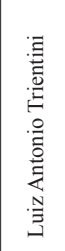 \\
\hline 을 & 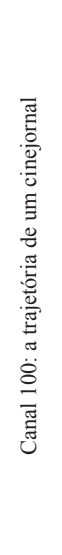 & 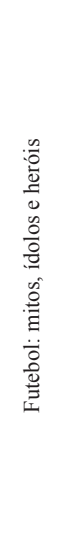 & 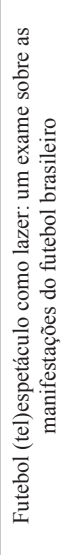 & 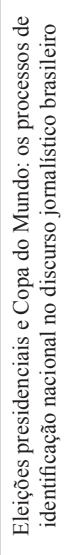 & 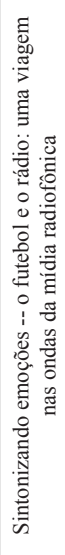 & 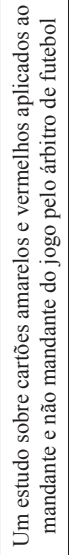 & 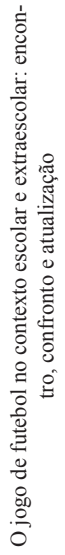 & 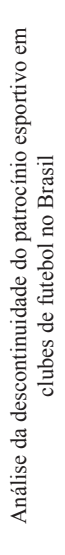 & 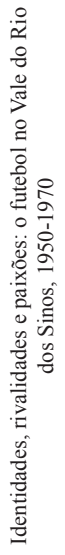 & 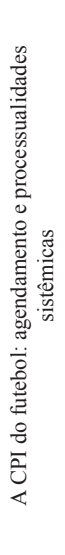 & 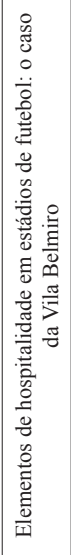 & 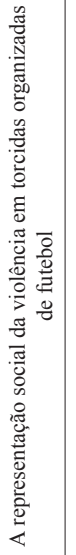 & 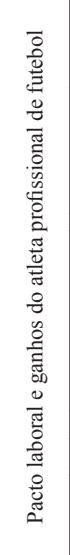 & 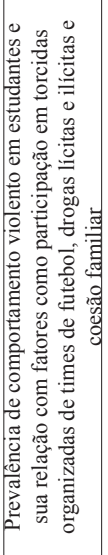 & 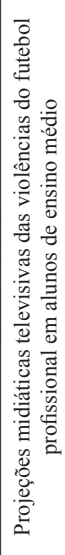 \\
\hline
\end{tabular}




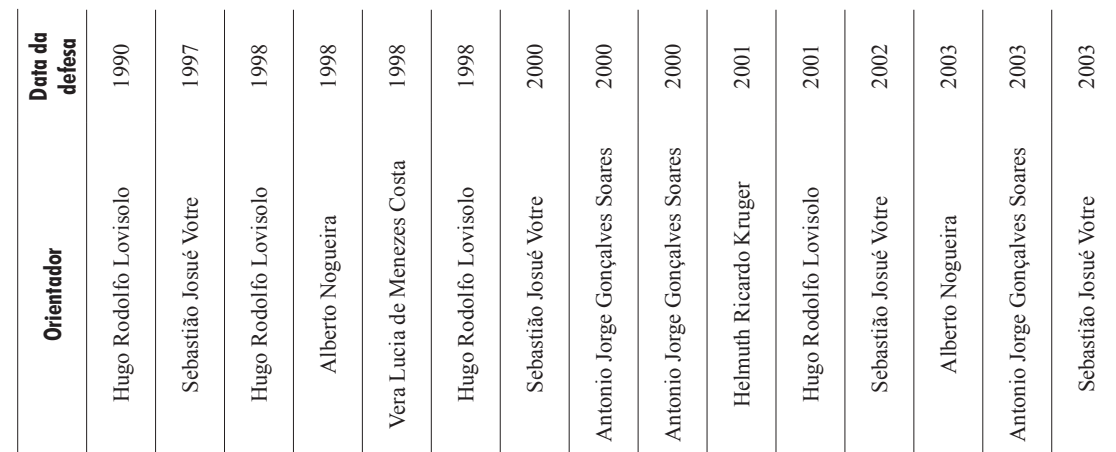

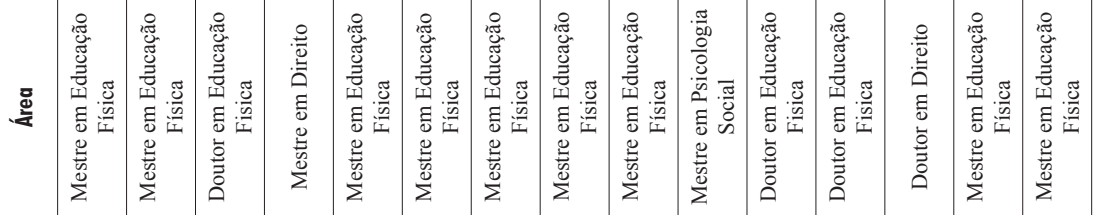

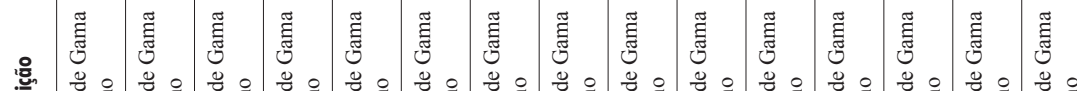

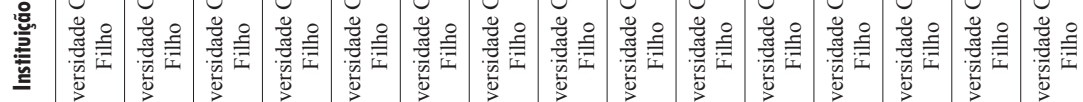

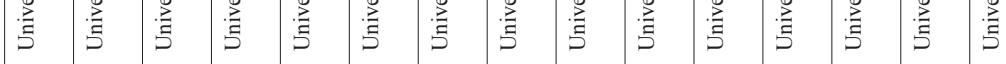

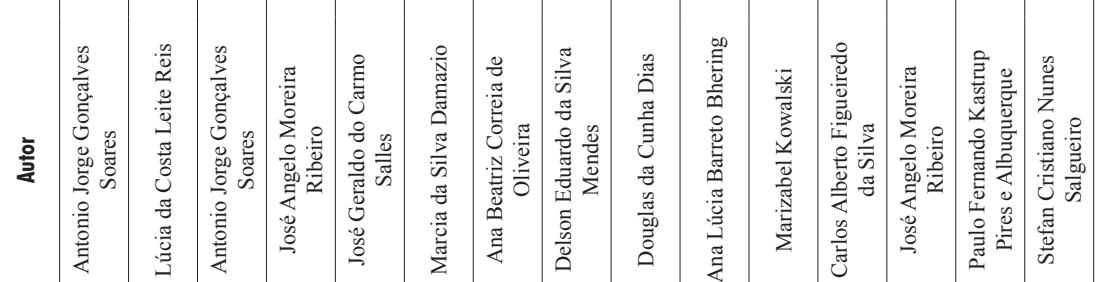

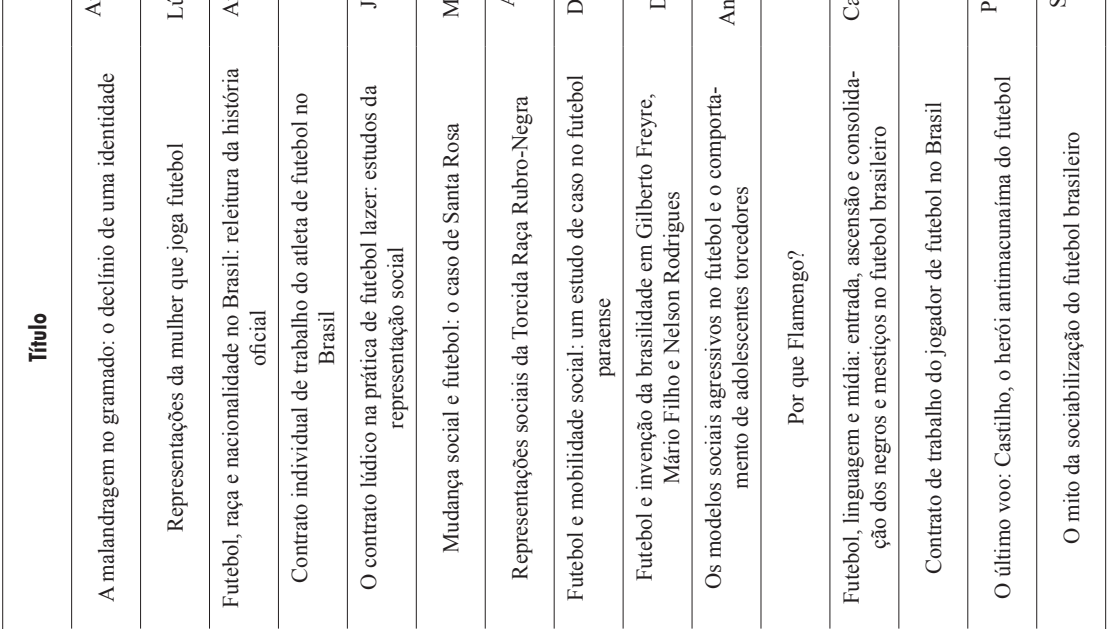




\begin{tabular}{|c|c|c|c|c|c|c|c|c|c|c|c|c|c|c|c|}
\hline 믐 & ণ্ণ & స్ & ః్ & $\stackrel{\sim}{0}$ & ః్ & $\approx$ & ते & 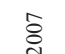 & 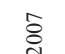 & & & 2 & อ & & \\
\hline 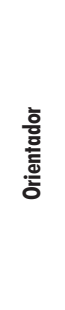 & 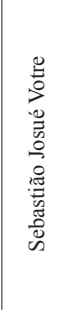 & 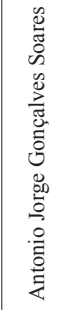 & 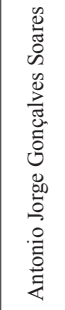 & 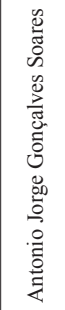 & 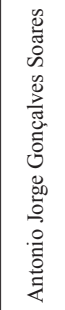 & 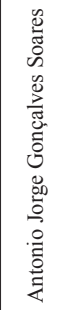 & 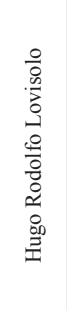 & 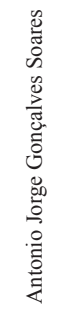 & 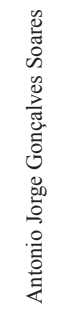 & 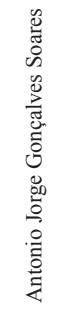 & 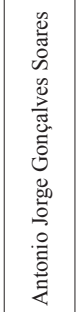 & 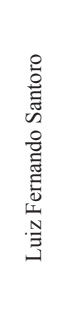 & 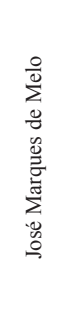 & 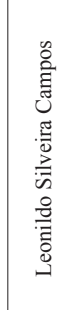 & 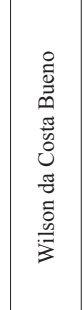 \\
\hline 党 & 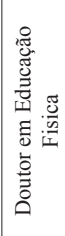 & 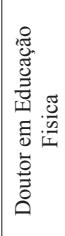 & 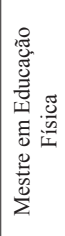 & 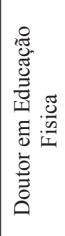 & 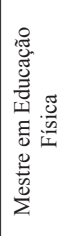 & 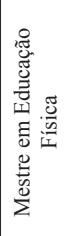 & 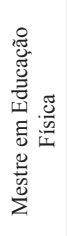 & 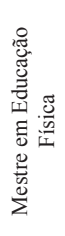 & 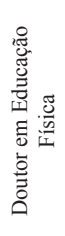 & 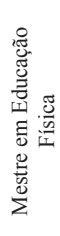 & 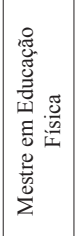 & 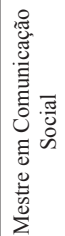 & 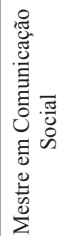 & 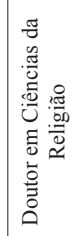 & 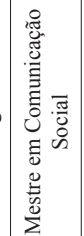 \\
\hline 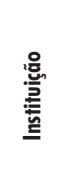 & 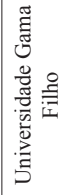 & 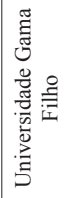 & 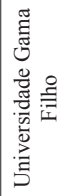 & 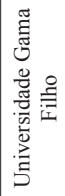 & 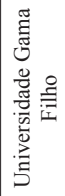 & 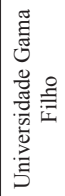 & 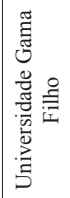 & 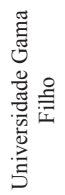 & 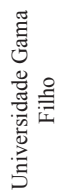 & 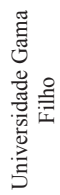 & 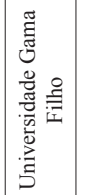 & 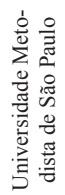 & 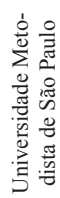 & 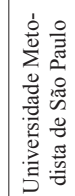 & 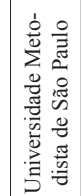 \\
\hline$\frac{\overline{0}}{3}$ & 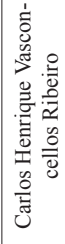 & 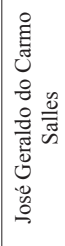 & 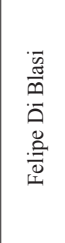 & 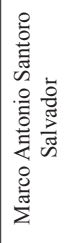 & 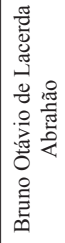 & 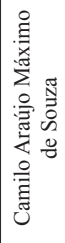 & 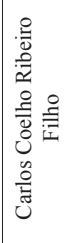 & 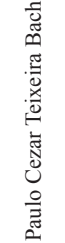 & 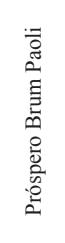 & 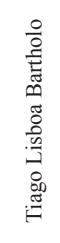 & 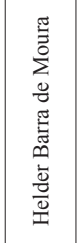 & 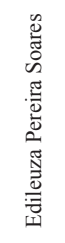 & 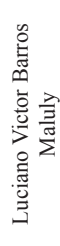 & 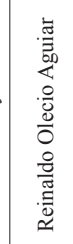 & 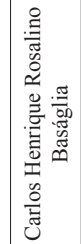 \\
\hline 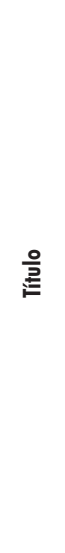 & 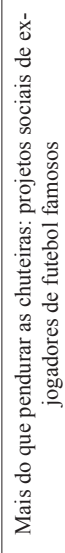 & 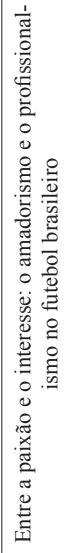 & 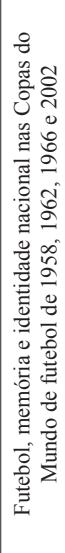 & 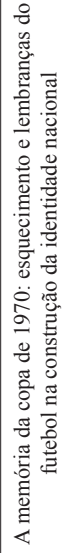 & 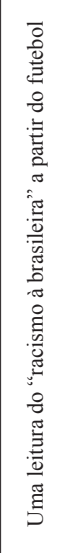 & 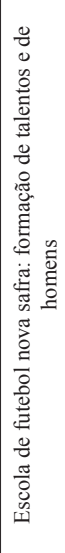 & 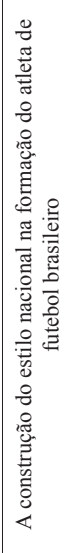 & 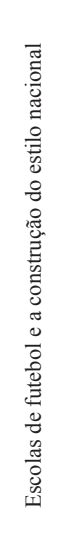 & 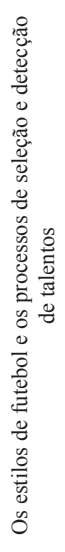 & 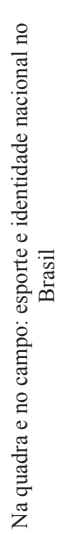 & 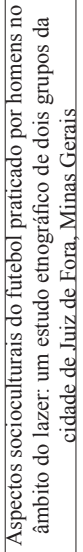 & 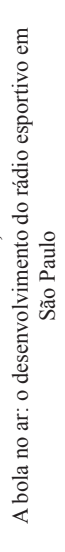 & 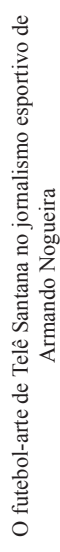 & 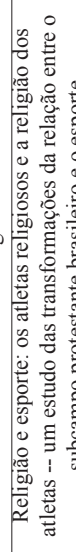 & 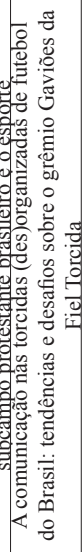 \\
\hline
\end{tabular}


Sérgio Settani GIGLIO e Enrico SPAGGIARI. A produção das ciências humanas sobre futebol no Brasil

\begin{tabular}{|c|c|c|c|c|c|c|c|c|c|c|c|c|c|c|c|}
\hline 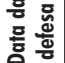 & ڤ్ & 產 & ठิ & ڤ్ڤે & ڤ్ & よ & ळ & 童 & ஃ̊ & $\stackrel{2}{\circ}$ & $\stackrel{\infty}{\circ}$ & ूे & よे & ¿্ণ & ๕ి \\
\hline $\begin{array}{l}\text { 흠 } \\
\text { 흫 } \\
\text { 힣 }\end{array}$ & 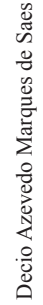 & 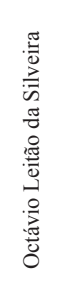 & 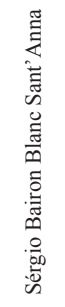 & 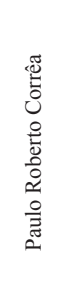 & 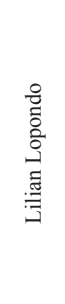 & 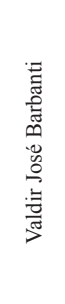 & 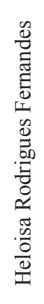 & 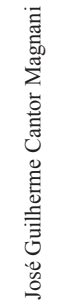 & 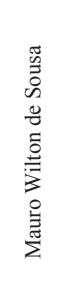 & 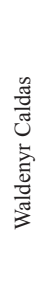 & 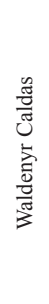 & 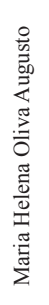 & 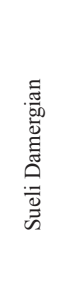 & 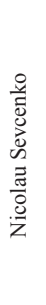 & 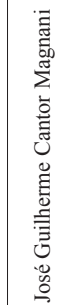 \\
\hline 莺 & 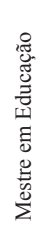 & 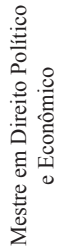 & 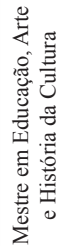 & 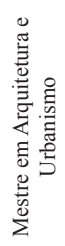 & 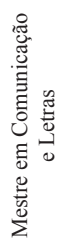 & 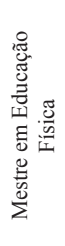 & 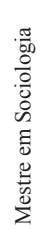 & 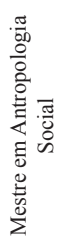 & 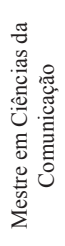 & 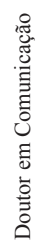 & 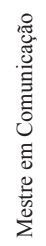 & 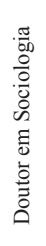 & 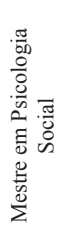 & 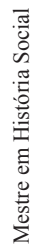 & 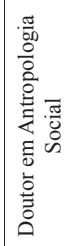 \\
\hline
\end{tabular}

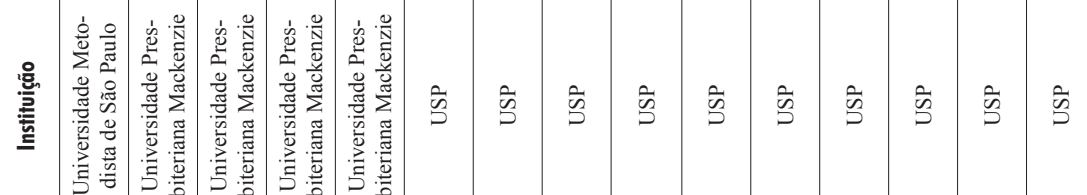

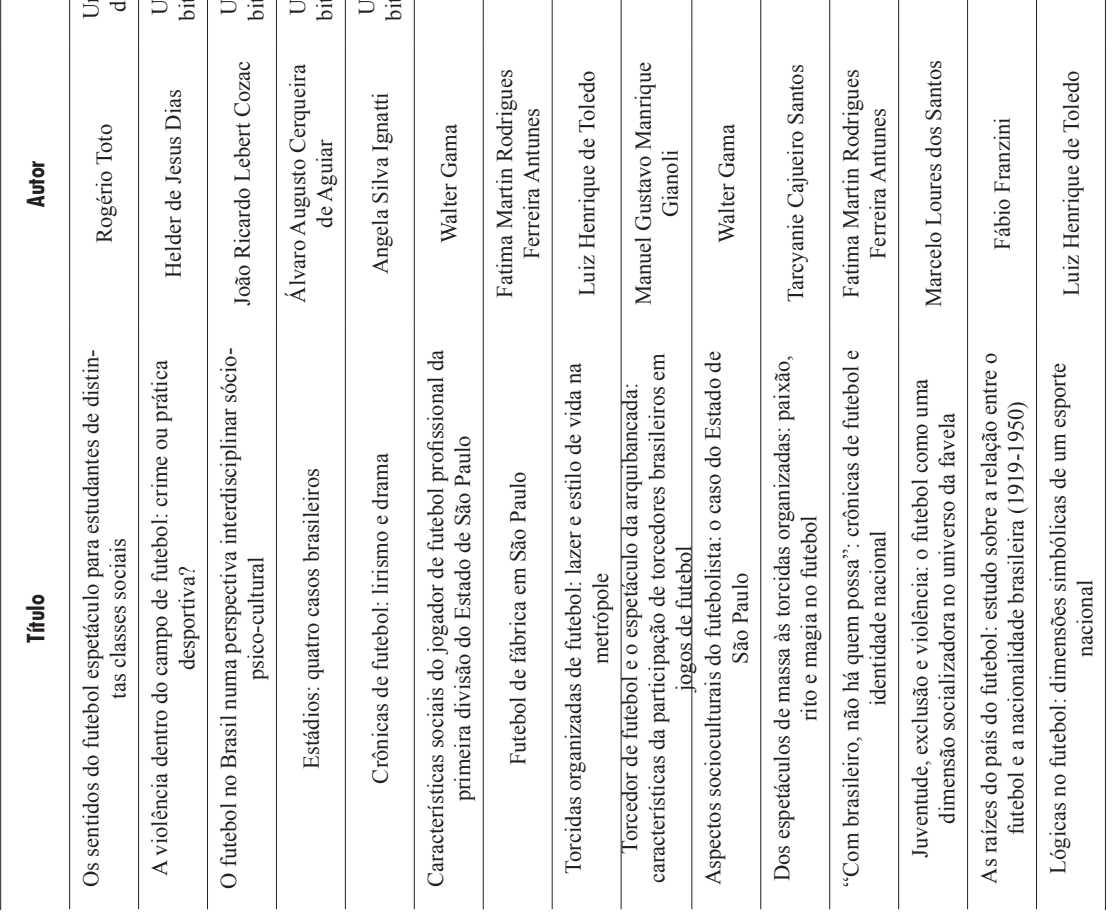




\begin{tabular}{|c|c|c|c|c|c|c|c|c|c|c|c|c|c|c|c|}
\hline 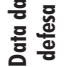 & ષ્సి & $\stackrel{\sim}{~}$ & ڤ్ & $\stackrel{\sim}{\circ}$ & $\stackrel{\sim}{\circ}$ & ڤ్ & ڤ్ & ठ্ণ & ه్ & ષ્ণ & ठ্ণ & ڤ్ & ¿্ণ & ¿্ণ & ¿্ণ \\
\hline $\begin{array}{l}\frac{\text { 흠 }}{\bar{t}} \\
\text { 흫 }\end{array}$ & 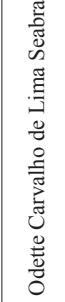 & 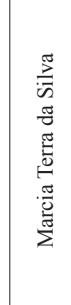 & 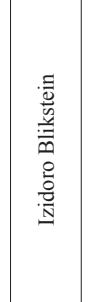 & 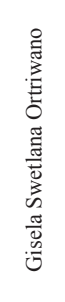 & 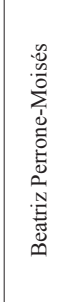 & 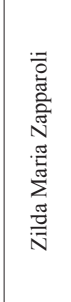 & 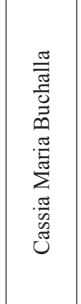 & 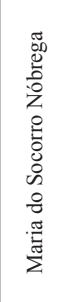 & 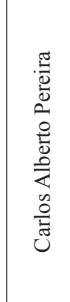 & 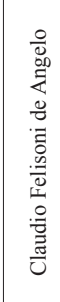 & $\begin{array}{l}\frac{\pi}{5} \\
0 \\
0 \\
0 \\
.0 \\
0 \\
3 \\
0 \\
0 \\
0 \\
0 \\
0\end{array}$ & 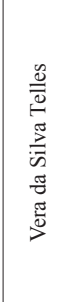 & 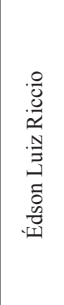 & 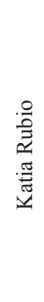 & 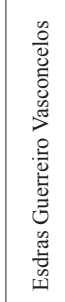 \\
\hline 龸 & 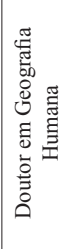 & 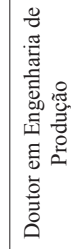 & 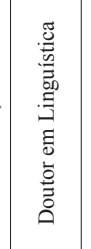 & 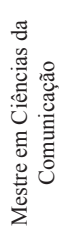 & 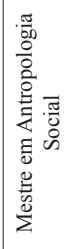 & 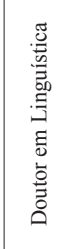 & 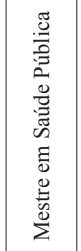 & 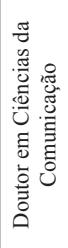 & 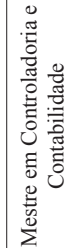 & 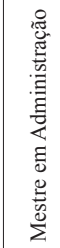 & 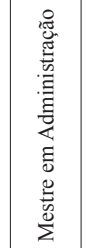 & 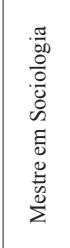 & 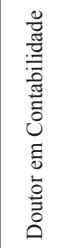 & 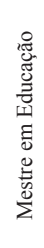 & 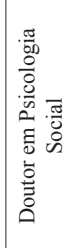 \\
\hline $\begin{array}{l}\text { 总 } \\
\text { 总 } \\
\text { 竞 }\end{array}$ & 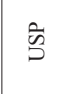 & $\begin{array}{l}\tilde{\tilde{D}} \\
\vec{D}\end{array}$ & 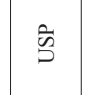 & के & 菅 & 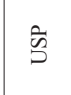 & 空 & 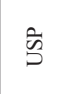 & 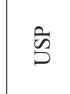 & 苫 & 芯 & $\begin{array}{l}\hat{n} \\
\text { مे }\end{array}$ & $\hat{\tilde{n}}$ & $\overrightarrow{\tilde{n}}$ & in \\
\hline 홀 & 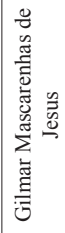 & 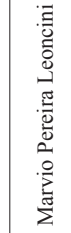 & 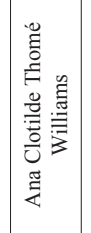 & 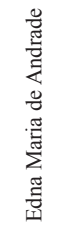 & 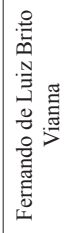 & 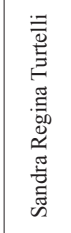 & 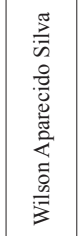 & 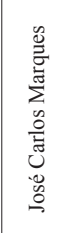 & 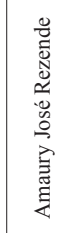 & 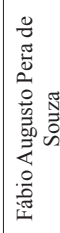 & 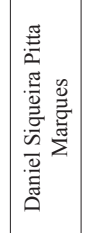 & 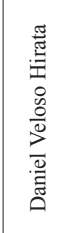 & 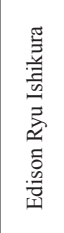 & 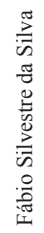 & 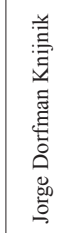 \\
\hline 을 & 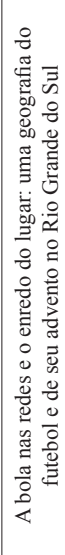 & 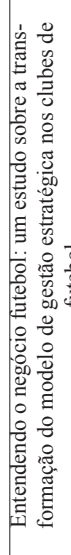 & 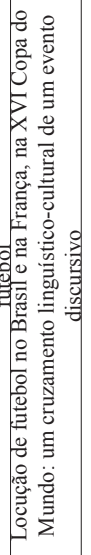 & 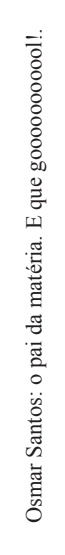 & 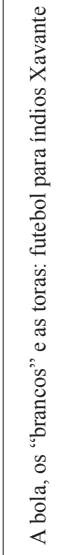 & 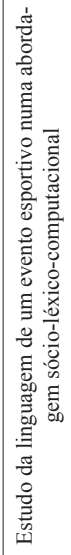 & 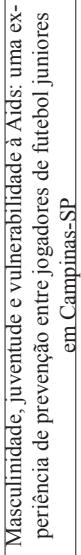 & 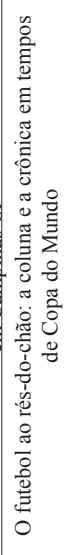 & 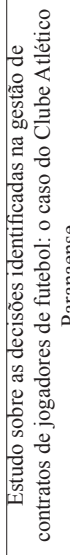 & 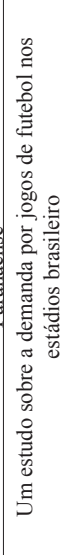 & 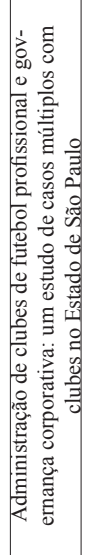 & 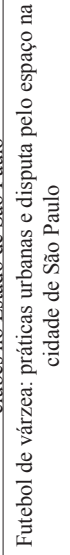 & 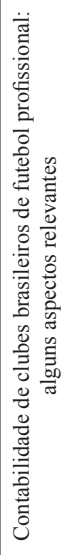 & 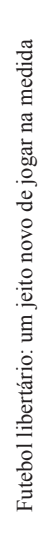 & 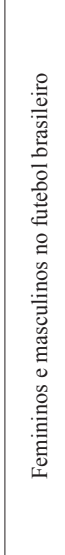 \\
\hline
\end{tabular}




\begin{tabular}{|c|c|c|c|c|c|c|c|c|c|c|c|c|c|c|}
\hline 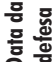 & ¿ั & ¿ั่ & ¿্ণ & 8 & 8 & ○े & 8 & 。ે & ¿̊. & 离 & $\stackrel{\infty}{0}$ & ळे & ఠิ & ڤి \\
\hline 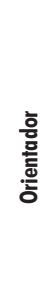 & 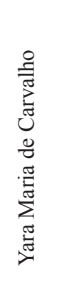 & 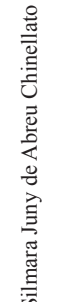 & 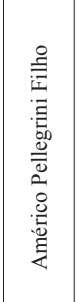 & 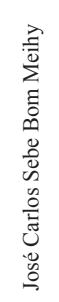 & 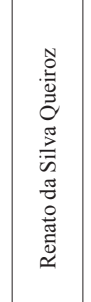 & 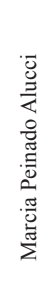 & 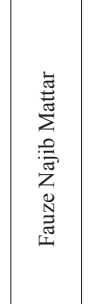 & 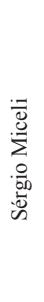 & 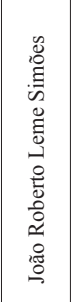 & 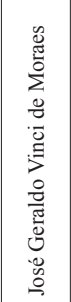 & 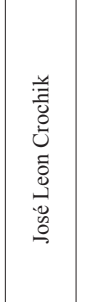 & 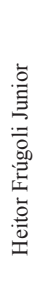 & 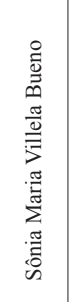 & 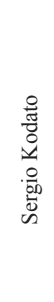 \\
\hline 常 & 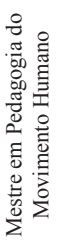 & 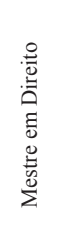 & 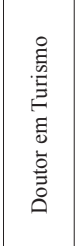 & 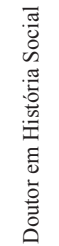 & 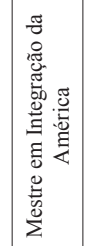 & 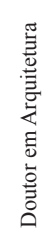 & 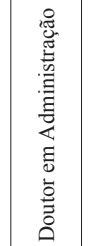 & 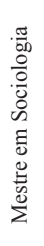 & 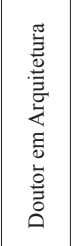 & 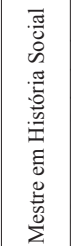 & 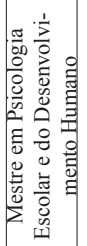 & 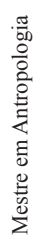 & 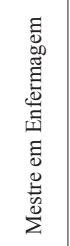 & 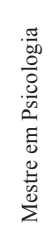 \\
\hline 总 & 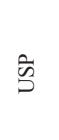 & 感 & हे & 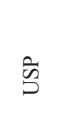 & हे & 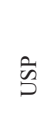 & ह̂े & 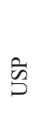 & हे & 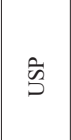 & 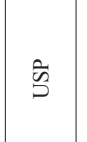 & 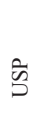 & 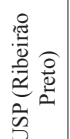 & 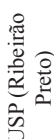 \\
\hline 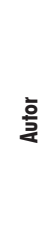 & 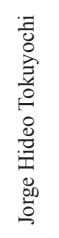 & 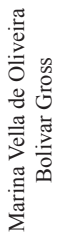 & 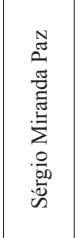 & 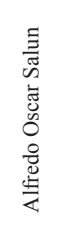 & 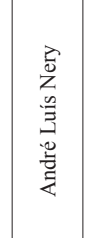 & 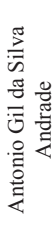 & 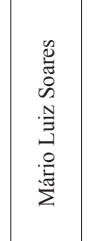 & 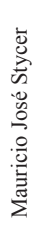 & 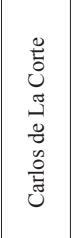 & 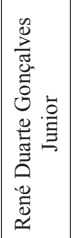 & 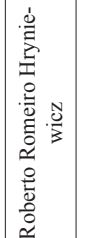 & 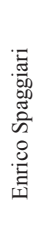 & 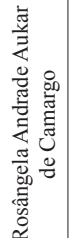 & 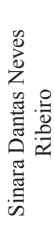 \\
\hline 을 & 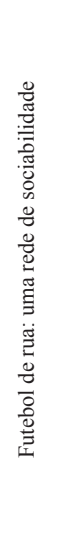 & 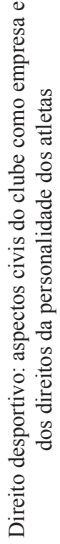 & 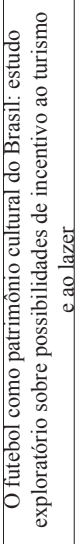 & 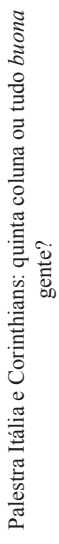 & 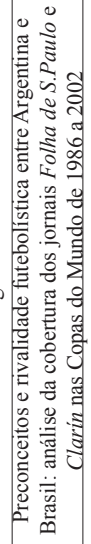 & 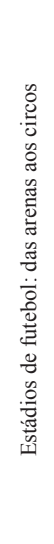 & 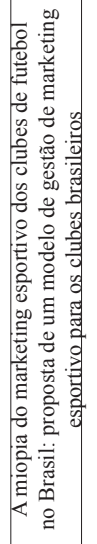 & 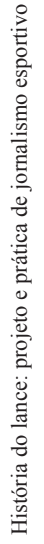 & 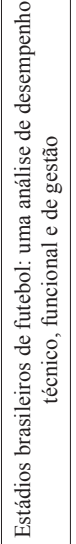 & 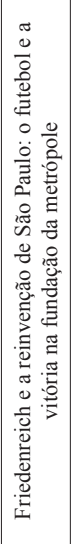 & 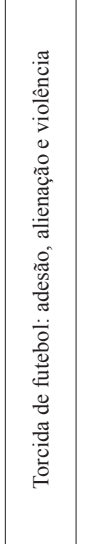 & 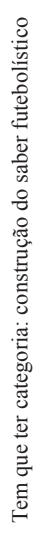 & 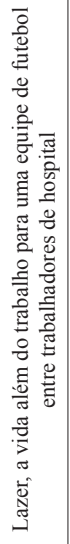 & 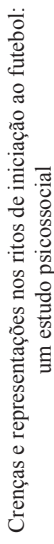 \\
\hline
\end{tabular}




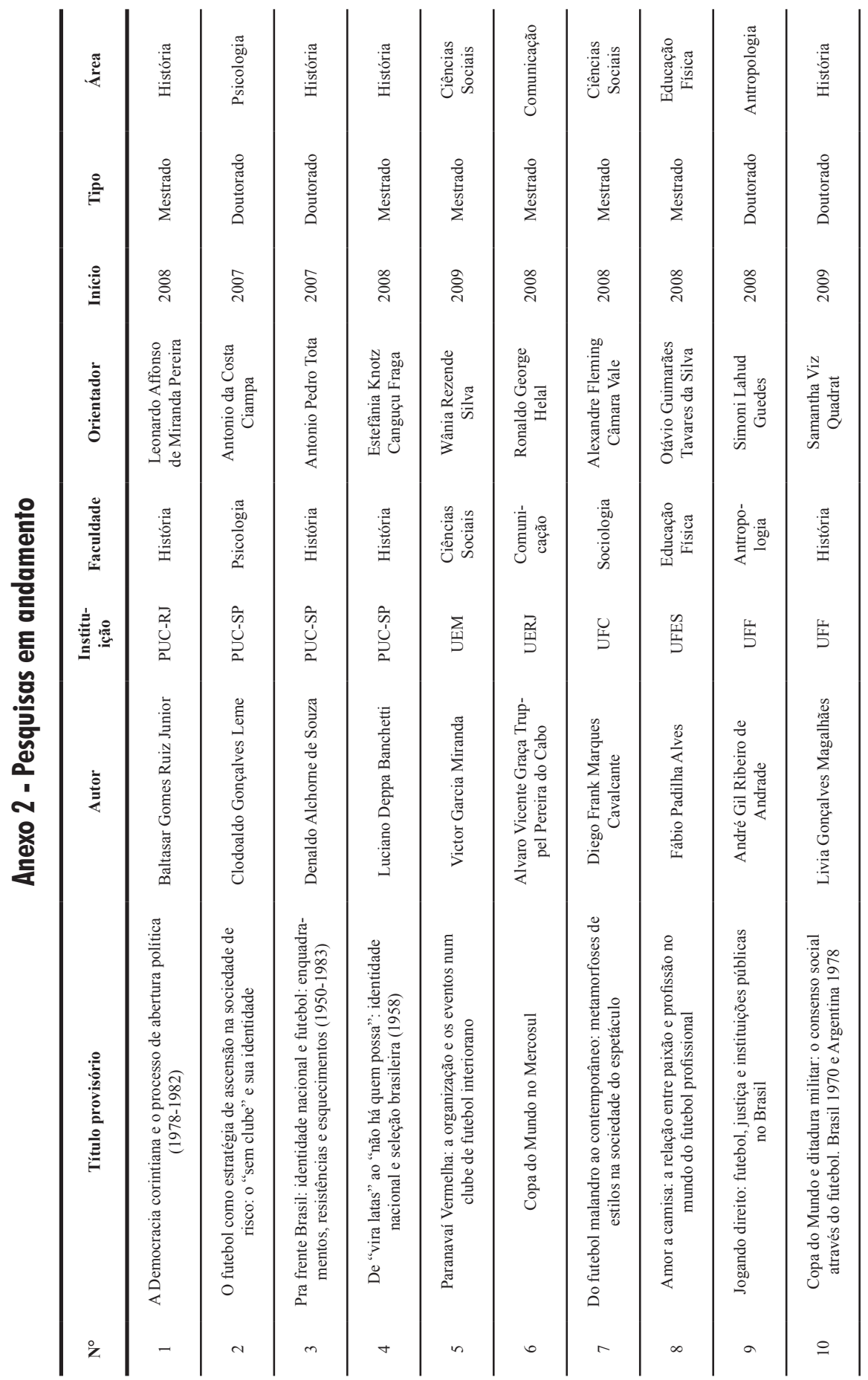


Sérgio Settani GIGLIO e Enrico SPAGGIARI. A produção das ciências humanas sobre futebol no Brasil

\begin{tabular}{|c|c|c|c|c|c|c|c|c|c|c|}
\hline 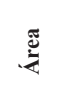 & 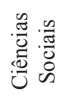 & 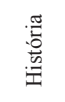 & 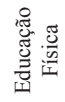 & 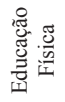 & 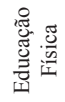 & $\begin{array}{l}\text { 胥 } \\
\text { 芯 } \\
\text { 吾 }\end{array}$ & 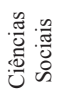 & 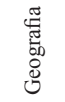 & 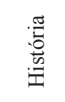 & 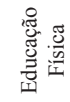 \\
\hline$\stackrel{\circ}{:}$ & 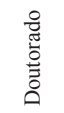 & 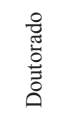 & 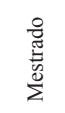 & 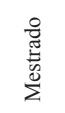 & 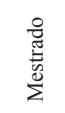 & 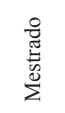 & $\begin{array}{l}\stackrel{8}{\mathbb{J}} \\
\stackrel{0}{0} \\
\stackrel{\overline{0}}{0}\end{array}$ & 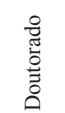 & 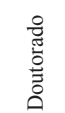 & 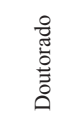 \\
\hline 坣 & $\hat{\mathrm{d}}$ & ஓे & $\stackrel{\infty}{\stackrel{్}{े}}$ & ڤ્ণે & ஓे & $\stackrel{\infty}{\stackrel{人}{~}}$ & ळे & $\hat{\overbrace{}}$ & $\stackrel{\infty}{\stackrel{人}{े}}$ & $\stackrel{\infty}{\stackrel{్}{े}}$ \\
\hline 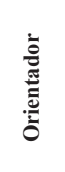 & 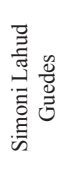 & 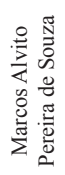 & 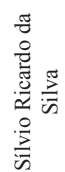 & 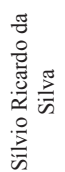 & 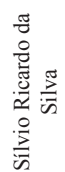 & 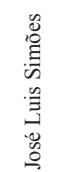 & 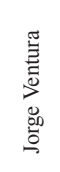 & 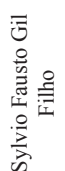 & 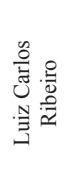 & 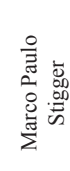 \\
\hline 营 & 总总 & 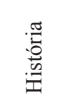 & 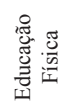 & 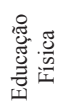 & 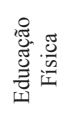 & $\begin{array}{l}\text { 总 } \\
\text { 芯 } \\
\text { 吾 }\end{array}$ & 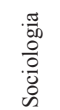 & 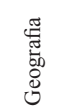 & 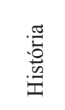 & 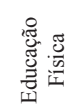 \\
\hline 总 惫 & 岌 & 岀 & $\sum_{S}^{0}$ & $\sum_{S}^{0}$ & $\sum_{S}^{0}$ & 嗀 & 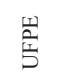 & 总 & $\frac{\stackrel{\alpha}{\Delta}}{\underline{S}}$ & $\begin{array}{l}0 \\
0 \\
\frac{2}{5}\end{array}$ \\
\hline 童 & 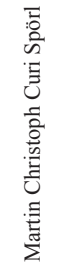 & 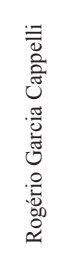 & 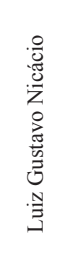 & 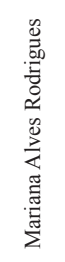 & 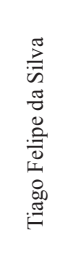 & 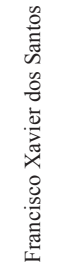 & 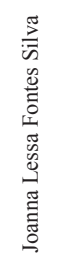 & 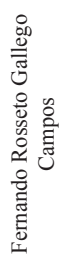 & 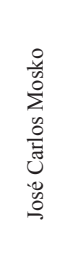 & 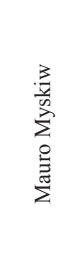 \\
\hline 을 & 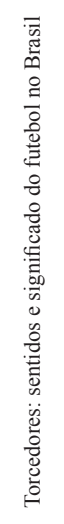 & 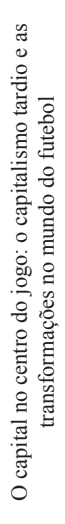 & 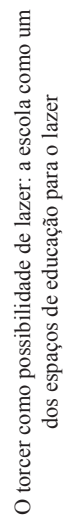 & 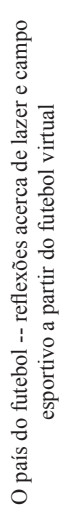 & 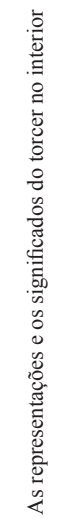 & 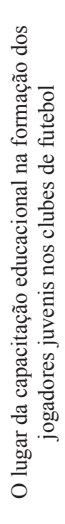 & 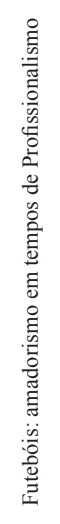 & 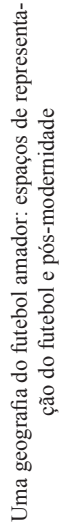 & 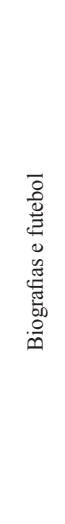 & 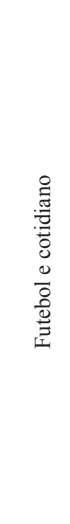 \\
\hline$z$ & $=$ & $\simeq$ & $\stackrel{m}{=}$ & $\Xi$ & 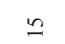 & 0 & $=$ & $\stackrel{\infty}{\sim}$ & 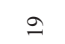 & ิ \\
\hline
\end{tabular}




\begin{tabular}{|c|c|c|c|c|c|c|c|c|c|c|}
\hline 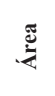 & 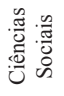 & & 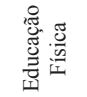 & 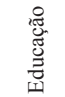 & 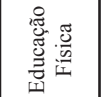 & 迅 & 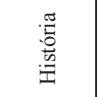 & 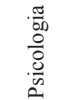 & 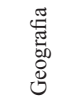 & 莺 \\
\hline$\stackrel{\varrho}{\cong}$ & $\begin{array}{l}\frac{8}{\pi} \\
\frac{\pi}{5} \\
\Sigma\end{array}$ & $\begin{array}{l}\stackrel{8}{\pi} \\
\stackrel{0}{0} \\
0\end{array}$ & 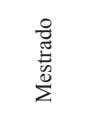 & $\begin{array}{l}\stackrel{8}{0} \\
\overline{0} \\
\stackrel{0}{0} \\
0\end{array}$ & 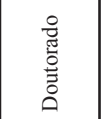 & 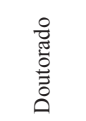 & 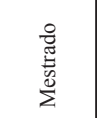 & 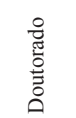 & 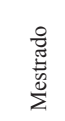 & 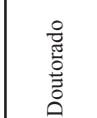 \\
\hline 象 & \&્స & $\hat{\stackrel{N}{े}}$ & ષ્ণે & ङ્તે & હे & ఫ્તે & ذ્خે & 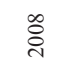 & 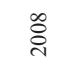 & 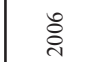 \\
\hline 离 & 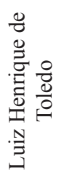 & 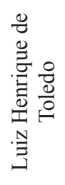 & 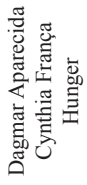 & 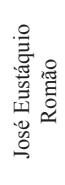 & 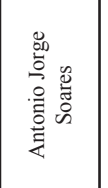 & 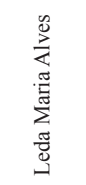 & 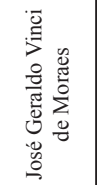 & 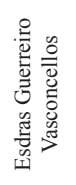 & 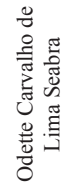 & 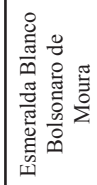 \\
\hline 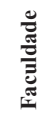 & 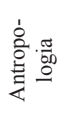 & 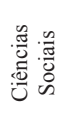 & 总 & 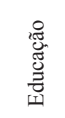 & 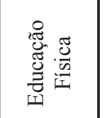 & 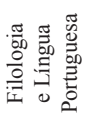 & 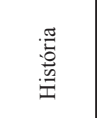 & 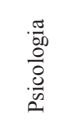 & 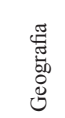 & 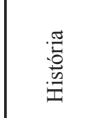 \\
\hline 竞。 & $\begin{array}{l}\text { 莺 } \\
\text { 岁 }\end{array}$ & $\begin{array}{l}\overrightarrow{\tilde{W}^{3}} \\
\text { 岁 }\end{array}$ & $\begin{array}{l}\text { क्षे } \\
\text { है }\end{array}$ & 䓂 & 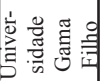 & $\vec{n}$ & $\begin{array}{l}\hat{n} \\
\text { ñ }\end{array}$ & 亗 & 芯 & 苛 \\
\hline$\vec{s}$ & 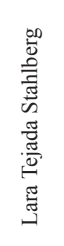 & 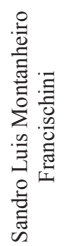 & 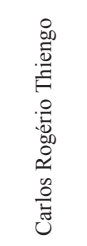 & 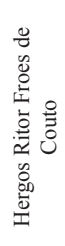 & 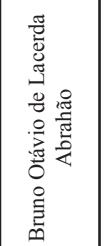 & 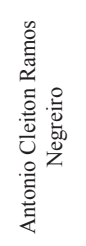 & 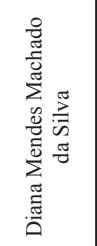 & 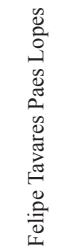 & 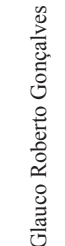 & 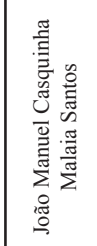 \\
\hline 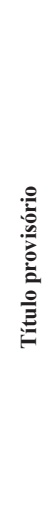 & 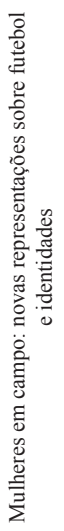 & 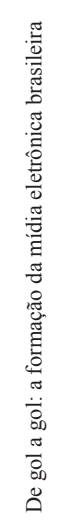 & 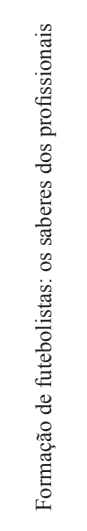 & 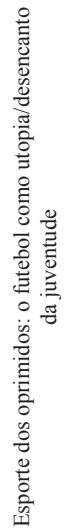 & 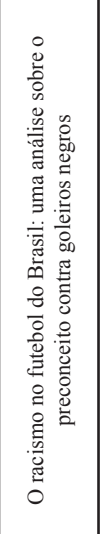 & 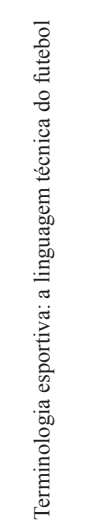 & 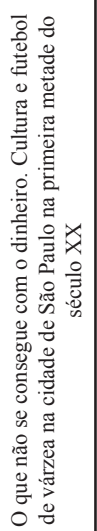 & 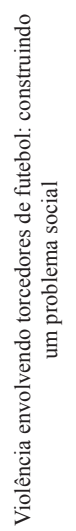 & 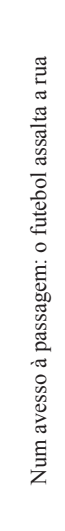 & 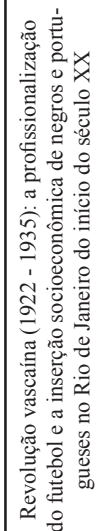 \\
\hline iz & $\vec{\sim}$ & สี & $\tilde{\lambda}$ & $\underset{\sim}{\stackrel{ \pm}{ }}$ & $\tilde{\sim}$ & $\underset{\sim}{\text { i }}$ & $\hat{\sim}$ & $\stackrel{\infty}{\sim}$ & तi & ల్ల \\
\hline
\end{tabular}


Sérgio Settani GIGLIO e Enrico SPAGGIARI. A produção das ciências humanas sobre futebol no Brasil

\begin{tabular}{|c|c|c|c|c|c|c|}
\hline . & 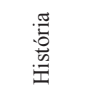 & 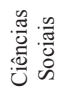 & 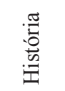 & 苞 & 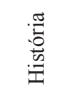 & 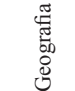 \\
\hline$\stackrel{\varrho}{\Xi}$ & 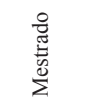 & 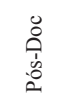 & 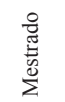 & 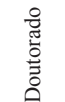 & $\begin{array}{l}\stackrel{\circ}{\mathbb{E}} \\
\sum_{\tilde{E}}^{5}\end{array}$ & 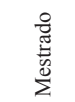 \\
\hline : & ڤ్రి & ठ્ेે & ڤ్ & \&్సి & ڤ్రి & ڤ્సે \\
\hline 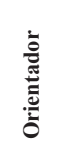 & 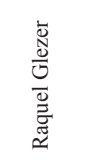 & 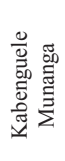 & 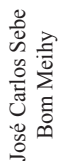 & 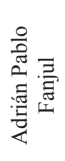 & $\begin{array}{l}\text { o } \\
\text { 言 } \\
0 \\
0 \\
0 \\
0 \\
0 \\
\text { : }\end{array}$ & 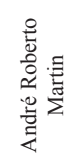 \\
\hline 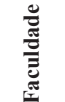 & 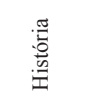 & 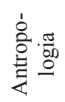 & 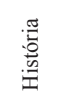 & 莺 & 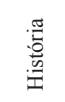 & 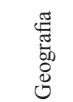 \\
\hline 总惫 & 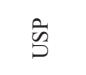 & 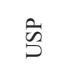 & है & 崩 & $\overrightarrow{\tilde{s}}$ & $\vec{n}$ \\
\hline 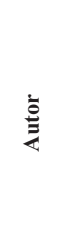 & 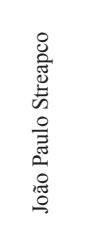 & 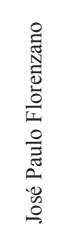 & 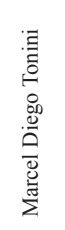 & 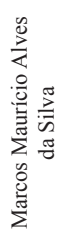 & 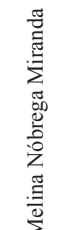 & 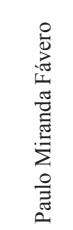 \\
\hline 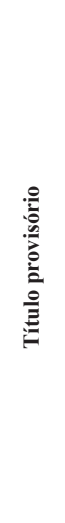 & 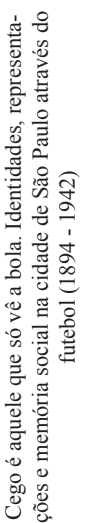 & 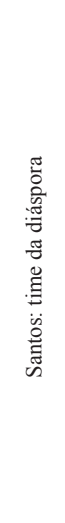 & 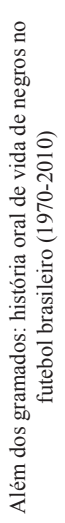 & 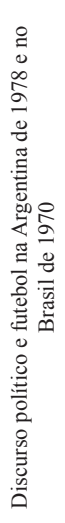 & 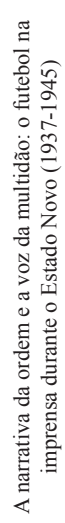 & 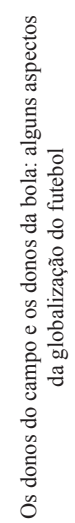 \\
\hline Z & $\bar{m}$ & लె & $\ddot{m}$ & $\stackrel{J}{m}$ & $m$ & ల \\
\hline
\end{tabular}

